Journal of the Scientific Agricultural Society of Finland

Vol. 51: 239-326, 1979

Maataloustieteellinen Aikakauskirja

\title{
EFFECT OF MOISTURE AND FREEZING ON SOME PHYSICAL PROPERTIES OF CLAY SOILS FROM PLOUGH LAYER
}

Selostus: Kosteuden ja jäätymisen vaikutus eräisiin muokkauskerroksesta otettujen savimaanäytteiden fysikaalisiin ominaisuuksiin

\author{
S I M O K I I S A A R I \\ Department of Agricultural Chemistry \\ University of Helsinki \\ SF-00710 Helsinki 71, Finland
}

ACADEmic DisSertation

TO BE PRESENTED, WITH THE PERMISSION OF the Faculty of Agriculture AND Forestry OF THE UNIVERSITY OF HELSINKI, FOR PUBLIC criticism in Auditorium XII on September 26, 1979, AT 12 o'Clock 
ISBN 951-9041-09-5

ISSN 0024-8835 


\section{Preface}

This study was carried out at the Department of Agricultural Chemistry, University of Helsinki. I owe a debt of gratitude to my teacher, Professor Armi KAILA, Head of the Department, for the support she gave me in my work over a long period of time.

It pleases me to thank Professor Viljo PuUstjärvi and Professor PAavo Elonen for checking my work and giving me valuable constructive criticism.

I would like to thank Doctor Antri JaAKкola who has given me valuable help in the collection of soil samples and construction of laboratory equipment.

In the practical tasks involved in carrying out the study, I was assisted by Mrs Marita Hagman, Miss Kaija Tuominen and Miss Seija Ovaskainen, whom I want to thank for their work. My thanks also go to Miss Orli TANSKa who has drawn all the figures presented.

Mrs. Sevastiana Ruusamo, M. A., has checked the English translation. I want to express my appreciation for her work.

To help finance my research work, I received grants from Suomen Kulttuurirahasto (The Finnish Cultural Foundation). Finally, I am grateful to the Scientific Agricultural Society of Finland for accepting my paper for inclusion in its series of publications.

Helsinki, May 1979

Simo Kivisaari 



\section{CONTENTS}

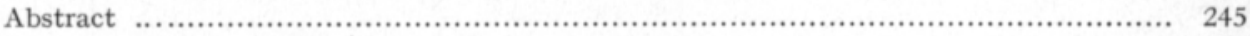

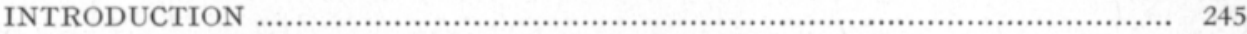

A. SOME EARLIER STUDIES ON SOIL FROST IN AGRICULTURE .............. 247

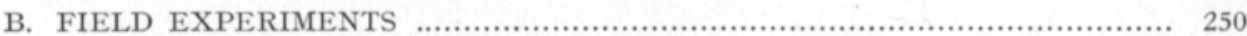

I Measurements of soil temperature and frost depth ............................. 250

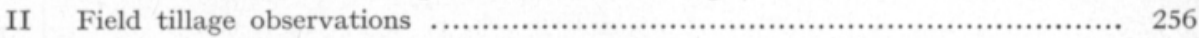

III Effect of freezing in field and laboratory on soil water retention $\ldots \ldots \ldots \ldots \ldots . .258$

C. STUDIES IN THE LABORATORY WITH COLLECTED SAMPLES ............. 262

I Research material ....................................................................... 262

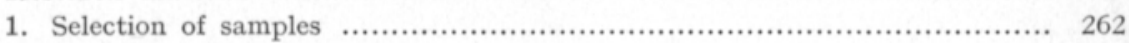

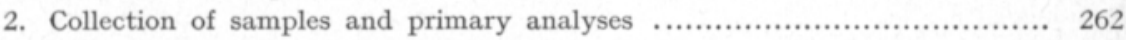

3. Classification of samples .................................................... 263

II Effect of freezing and wetting-drying on the water retention of disturbed

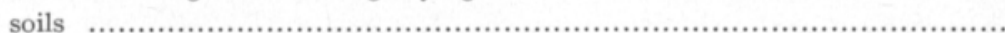

1. Effect of freezing and wetting-drying treatment on water retention of suspended soils .................................................................... 265

2. Effect of freezing on water retention of fine ground soils .................. 266

III Effect of freezing on the stability of soil aggregates ............................ 268

1. Pre-treatment of aggregates for stability analyses .......................... 269

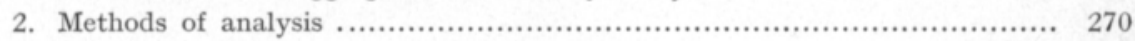

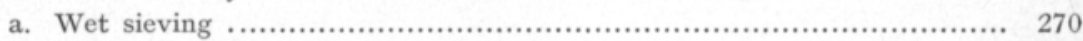

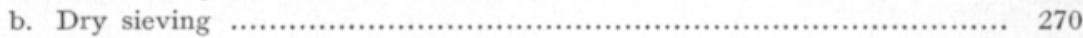

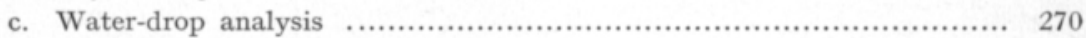

3. Results of the stability analyses ............................................ 271

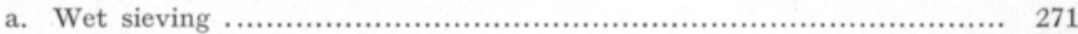
b. Dry sieving ........................................................................ 273
c. Water-drop analysis ......................................................... 274

IV The freezing mechanism as a factor changing the aggregate porosity ......... 278

1. Pre-treatments of aggregates for total pore volume determinations ......... 278

a. Preparation of aggregates for determination of total pore volume as moist 278

b. Preparation of aggregates for determination of total pore volume of frozen, thawed and air dried aggregates ................................ 278

c. Preparation of aggregates for determination of total pore volume of moistened and air dried aggregates ........................................... 279

d. Preparation of aggregates for determination of total pore volume of

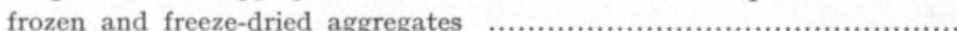

2. Determination of total pore volume of aggregates ..............................

a. Determination of the total pore volume of aggregates by the modified method of SUNKEL

b. Testing the method of determination of total pore volume .............. 281

3. Total pore volumes of aggregates and their changes ....................... 282 
a. Total pore volumes of moist aggregates

b. Changes of total pore volumes of aggregates after freezing, thawing and air drying

c. Changes of total pore volumes of aggregates after wetting and air drying

d. Changes of total pore volumes of aggregates after freezing and freezedrying

$\mathrm{V}$ The role of water movement due to freezing determining the change of soil structure

1. The amounts of moved water

a. Measuring the amounts of moved water ................................. 294

b. Movement of water in a small soil cylinder prepared from paste ....... 295

c. Movement of water in a small soil cylinder prepared as dry ............ 298

d. Movement of water in a big soil cylinder ............................... 300

2. Effect of water movement on the total pore volume of soil cylinders .... 305

a. Effect of water movement on the total pore volume of small soil cylinders 306

b. Effect of water movement on the total pore volume of big soil cylinders 309

DISCUSSION

312

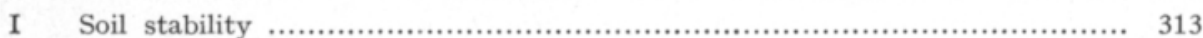

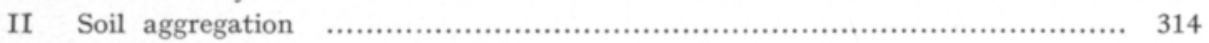

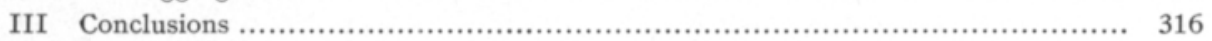

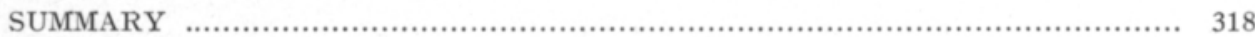

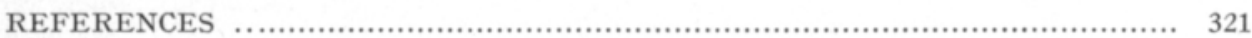

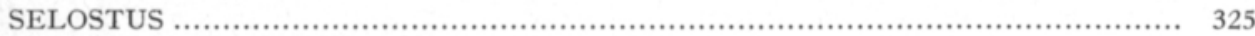




\title{
KivisaARI, S. 1979. Effect of moisture and freezing on some physical
} properties of clay soils from plough layer. J. Scient. Agric. Soc. Finl. 51: 329-326.

\begin{abstract}
The aim of this study was to elucidate the effects of freezing on some structural properties of clay soils. The laboratory analyses were based on field observations including measurements of soil temperature and frost depth.

The daily temperatures showed remarkable variations on the very soil surface both in the autumn and spring, ranging from below zero at night-time to above $10^{\circ} \mathrm{C}$ at daytime. The depth of soil frost was deepest in the ploughed field, whilst the straw cowers on the soil surface not only strongly reduced its depth, but also slowed up the thawing.

Eight clay soil samples were analyzed in the laboratory. At the potentials of -0.001 to -0.1 bar the water retention capability of soil was reduced by freezing. Disruption of the 5-10 mm aggregates by freezing, analyzed with wet and dry sievings and waterdrop analysis was strongly dependent on the water potential, the water potential of -1.0 bar or lower having in general no effect.

The total pore volume of aggregates was dependent on the water potential when it exceeded -15.0 bar. Freezing had a minor effect on the pore volume of the aggregates, if they were let to thaw before drying. The freeze-dried aggregates showed a clear increase of pore volume when the water potential at freezing exceeded -1.0 bar.

The movement of water due to ice formation was studied with small and big soil cylinders. It showed a great effect on the structure, if total pore volume, determined with a mercury method, is considered the standard of judgement. Thus it was concluded that the water movement even at a short freezing period is one of the most essential factors determining the structural formation of ploughed clay soil.
\end{abstract}

\section{Introduction}

Soil frost is one of the most regular phenomena in the fields in Finnish climatic conditions. Because it affects many domains of everyday life, it has been the object of intensive research work in the countries where soil frost exists. This research work includes also studies dealing with the effects of forst on the structural properties of cultivated soils.

There is hardly any disagreement as to the effects of soil frost on the field structure. Czeratzki (1971) states that it is one of the most significant factors which affect the tillering properties of heavy clay soils under these climatic conditions. Many farmers, too, know by experience that without frost the heavy clay soils would be difficult to cultivate, and this has also been pointed out by KOKKONEN (1944). 
But, in spite of the effects of frost in general being regarded as significant and the phenomenon itself wals den reizvollsten" (CzERATZKi 1971), there are surprisingly few studies on it, particularly on its effects on the workability of soil and the mechanisms affecting deformation of soil structure. One reason for this may be the fact that soil structure in general is not an unambiguous conception and, therefore, several experiments of different types are needed to approach and understand this phenomenon. The simple qualitative analyses employed in the studies on soil frost will give only limited information on the freezing processes in soils.

The depth of soil frost as a factor affecting soil structure is often connected with the traditional conception of soil frost. It is obvious that this is important when determining certain processes in soils particularly in the engineering. The significance of frost depth may, however, be limited when determining the structural formation of soil surface during the winter. Therefore, the purpose of the present study is to establish the factors occurring in winter affecting the differentiation of plough layer. The study is based on some field observations and some qualitative analyses made on the basis of these observations. The most fundamental part of the work is, however, the latter part which deals with aggregation of the surface layer of clay soils during the winter. The question is, what mechanism makes the soil aggregate as a result of freezing. 


\section{A. Some earlier studies on soil frost in agriculture}

Professor E. Wollny, a German scientist, discussed also the problems of soil frost in his large serial "Forschungen auf dem Gebiete der AgrikulturPhysik», published at the end of the last century. It was taken up in three separate papers and the same subject was also reviewed on the basis of the results published in other papers. Furthermore, the problems of frost injuries to plants also recieved much attention in this serial.

The freezing phenomenon in soil was fairly well known at the end of the last century compared to the information available today, although the technical possibilities to perform measurements were more limited and the knowledge about the molecular structure of water, ice and solid components of soil was not so far advanced as it is in our days. Thus, it was perhaps for the first time among the soil scientists that PETIT (1893) found out that the water in soil first goes through the stage of subcooled water before the actual freezing. The subcooling occurs in clay soils at lower temperatures than in sandy soils, and the relative proportion increases as the amount of water decreases. Petit confirms, "dass die Unterkühlungstemperatur des Bodenwassers um so tiefer gelegen ist, je grösser die Energie, mit welcher dasselbe seitens des Bodens festgehalten wird\%. In the same Wollny's annal, UlRICH (1897/98) points out the significance of salt concentration on the freezing point of soil water, and notes that different salts affect the soil differently. Thus, he wonders what the real effects of salt concentrations on the subcooling of soil water are.

Wollny's own paper on soil frost $(1897 / 98)$ deals with the effects of frost on the physical properties of soil. The number of papers he has written for the whole series is in its entirety very large and in this respect it is surprising, how thoroughly he has studied also this subject. In this study WoLLNy concentrated on six main categories of effects of soil frost:

The effect of frost on:

1. the strength of soil

2. the volume changes of soil

3. the structure of soil

4. the air permeability of soil

5. the water permeability of soil

6. the amount of water in soil.

The earliest Finnish studies on frost have been written by LEMsTröm (1893) and Номѐ N $(1893,1896,1897)$. Homè N's work from 1893 only partly deals with the freezing of the soil, whereas in the books from 1896 and 1897 he has 
published very accurate results of the measurements of temperature from a period of eight years. He has studied the factors affecting soil temperature, e.g. thickness of snow layer, amount of rain water and heat conductivity of soil.

The next Finnish researchers in the field of soil freezing were KERÄnEN, Kokkonen, and Simola in the 1920's. KerÄnen's (1920) dissertation study mainly concerned with the measurements of temperature in snow and soil, performed at a site in the north of Finland. Like the study of Homén (1896) also this study attempts to explain the factors which affect the soil temperature. He published a similar study three years later (KERÄNEN 1923 a). Neither study deals with the freezing phenomenon as a factor changing soil structure but rather as a purely physical problem affected by various components. $\mathrm{He}$ does not discuss the structural questions even in his other work of the same year (KERÄNEN 1923 b). Instead, he mentions in the conclusions the agricultural significance of frost, e.g. its harmful effects on the sprout of rye, the possibility of existence of snow mould on unfrozen soil, the fact that a deeply frozen soil warms up more slowly than less frozen soils and its effects on the change of soil volume.

Srmola (1923, 1926) explained the formation and thawing of frost and he studied the effects of ditching on the thickness of frozen layer and the speed of freezing. Problematic questions have been the depth of frost in ditched fields and the thawing of frost in different conditions. Homén (1895) once alleged that a considerable part of the frost thaws from below upwards. KERÄNEN (1920) and SIMOLA (1923) claimed, on the contrary, that in normal springs the thawing from below is of minor importance compared to the thawing from the top. The actual situation in the field depends, however, very much on the weather and soil type (Srmola 1926).

It is understandable that the agricultural researchers were not in the beginning of this century very much interested in the structural problems of soil. Soil structure was not a problem in the sense it is nowadays. It was more important to prevent the damaging effects of frost on plants and find the means to minimize those damages. Thus, Srmola (1930) states that in the cultivation of plants, one should strive to make the plants more resistant to the damages caused by the changes of temperature during winter and spring.

The papers of KoKKONEN were more geotechnical than those of the others mentioned. In the paper from the year 1926 he introduces the well known classification of different soil frost types. The same frost types were already mentioned in short in the study on the effects of frost on ditches (KoKKONEN 1924).

It is interesting that KERÄNEN (1924) in a short article mentions that soil frost has a favorable effect on soil structure and, therefore, it is recommendable to plough the fields already in the autumn, although he does not seem to have studied this question more deeply. It is likely that the phenomenon was regarded as self-evident. However, KoKkonen (1929) states that the effects of soil frost were worth studying not only on one but on all the soil types. According to him, theoretical explanations about the forming of soil frost should also be included in these studies.

In spite of KoKKonen's (1929) statement, soil frost was not studied very 
intensively in the 1930 's. The next study concerning particularly soil frost was the one published by JuUsela in 1941. The main aim of this study was to study the effects of draining of cultivated fields on the freezing and thawing. So did the later, much wider dissertation work from the year 1945 (JuUselA 1945) which was similar to the work of Simola (1926). KoкKonen (1942) presented some general observations of the effects of winter on the fields in a Finnish farm. In addition to JuUsela (1947) the problem concerning the resistance of drainpipes against soil frost has been discussed also by KEso (1951).

As a structural problem soil frost has been discussed in Finland by SillanPÄÄ (1961). In the same year he published a short paper with WEBBER (SIllanpäÄ and WebBer 1961). In all these papers the soil was treated as small crumbs and the effects of different freezing treatments on the crumb stability was examined. In the same decade, Andersson (1964) published in Sweden a study which concentrated mainly on the formation and thawing of soil frost.

Geotechnically interesting studies on soil frost are those of SovERI and JoHANSSON (1966) as well as SOVERI and VARJo (1977). The former contains some observations on freezing and thawing of soil frost on different soil types during the period 1958-1964. The latter is a more thorough report on the factors affecting the penetration of frost into soil. This study is based on a wide material collected by the Hydrological Institute. Both these reports concentrate in the analysis of the effects of soil frost depth and in both studies efforts are made to develop a formula to determine the depth of the frost on the basis of some primary values.

As seen above, the number of the studies on soil frost, as far as its effects on soil structure is concerned, is in Finland not very large. Indeed, this may be one reason why soil frost normally is understood as the thickness of the frozen layer existing in the winter. There is also a common view that the disruptive effect of soil frost on the top layer of soil is only beneficial without any negative influences. Its effect on the soil apparently is more often positive than negative and thus KoKKonen (1944) states, probably by experience, that sthe cultivation of the heavy clay soils in Finland would be impossible without the effects of soil frost, because without frost it would be difficult to get a good and friable structure on the soiln. 


\section{B. Field experiments}

\section{Measurements of soil temperature and frost depth}

During the winters 1971-78 different measurements of the depth of soil frost were made at two sites in the south of Finland: in Helsinki $\left(60^{\circ} 14^{\prime} \mathrm{N}\right)$ and Kiikala $\left(60^{\circ} 27^{\prime} \mathrm{N}\right)$. In addition to these measurements also the soil temperatures at different depths were followed. The main aim of these measurements was to establish the effects and class of magnitude of the factors which cause the soil to freeze and what their lasting period is normally in natural conditions in the field. The measurements made in different years were not identical and the procedures could be changed according to the need. Therefore, only part of the results have been presented in the following.

The experimental fields both consisted of a rather light clay soil. In the experimental field of Helsinki the clay content $(<2 \mu \mathrm{m})$ was $31 \%$, the content of $2-20 \mu \mathrm{m}$ size fraction was $23 \%$ and that of $20-200 \mu \mathrm{m} 44 \%$. The corresponding figures of the experimental field of Kiikala were $38 \%, 36 \%$ and $24 \%$. Particle size composition was determined by the method of EloneN (1971). The organic carbon contents estimated by the wet combustion method by Graham (1948) were $3.0 \%$ and $2.8 \%$ respectively. All the figures given, represent the values of ploughed layer.

The measurements of soil and air temperatures were made by the thermographs made by Lambrecht. The depth of soil frost was followed by the methylen blue method developed by GANDAHL (1957). The air temperature was measured in the Kiikala experimental field with a thermograph placed on the ground in the field. In the field of Helsinki it was measured in a specific weather observation box two meters above the soil surface. The box was located about $200 \mathrm{~m}$ from the experimental field.

In the experimental field of $\mathrm{K} \mathrm{i} \mathrm{i} \mathrm{k} \mathrm{a} \mathrm{l} \mathrm{a} \mathrm{the} \mathrm{soil} \mathrm{temperatures} \mathrm{of} \mathrm{unploughed}$ field were followed during the winter 1971-72. The measurements were made at four depths (Fig. 1). According to the curves of the thermographs, the temperature had sunk during the winter about 40 times below zero on the soil surface. In the autumn, the number was 33 and in the spring 9 . Most frequently the sinking of temperature occurred in the autumn in October-November and in the spring in April. Figure 2 shows the daily variations of the temperatures during the periods of Oct. 10th to Nov. 18th and April 1st to 30th in the air, at the soil surface $\left(D_{0}\right)$ and at the depth of $2.5 \mathrm{~cm}\left(D_{2.5}\right)$.

Almost regularly, the maximum temperature of soil surface has been both in the autumn and in the spring higher than the maximum air temperature. 

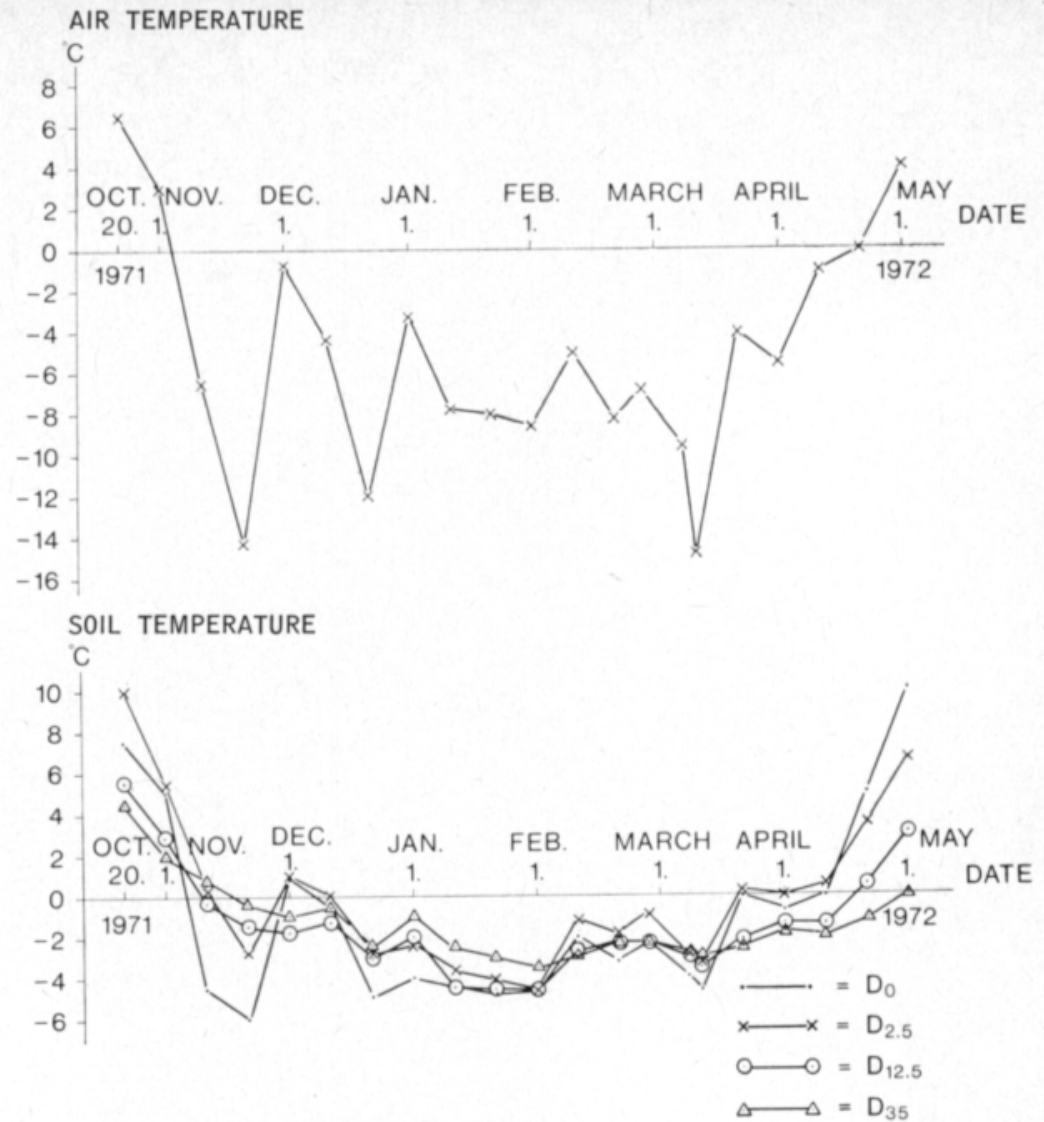

Fig. 1. Air and soil surface temperatures measured in the experimental field of Kiikala in the winter 1971-1972. $D_{o}=$ depth of measurement $0 \mathrm{~cm}, \mathrm{D}_{2.5}=2.5 \mathrm{~cm}, \mathrm{D}_{12.5}=12.5 \mathrm{~cm}$ and $\mathrm{D}_{35}=35.0 \mathrm{~cm}$. The values given, represent the mean values of four measurements during the day made at six-hour intervals.

Apparently, the difference between these maximum temperatures would have been greater if the soil surface temperature had been measured in the ploughed soil. It was, however, not possible because of the lack of measuring elements.

It is worth noticing that the soil surface temperature has risen markedly after the thawing of the soil surface frost on April 10th. Up to that time it stayed quite close to zero, even though the air temperature was not very much above zero. The occasional lowerings of the air temperature below zero after-April 10th seem not to have caused the soil temperature at the depth of $2.5 \mathrm{~cm}\left(\mathrm{D}_{2.5}\right)$ to sink below zero any more.

Another important point in these results is the great daily variations of soil surface temperatures. As is seen in Figure $2 \mathrm{~b}$, after April 10th there are at least 12 days when the daily variation of temperature has exeeded 14 degrees. On eight days out of these 12 days the temperature has sunk below zero. It is obvious that these great daily variations of temperature of the soil surface will have some tillering effect on the soil surface, particularly in the cases the 
temperature sinks below zero. Thus, it has been pointed out by Czeratzki $(1956,1971)$ that the ice needles in the surface of the soil makes the soil friable when lifting up the soil. The friable effect will be strengthened if the climatic situations are favorable to the sublimation of ice which diminishes the amount of water forming by thawing.

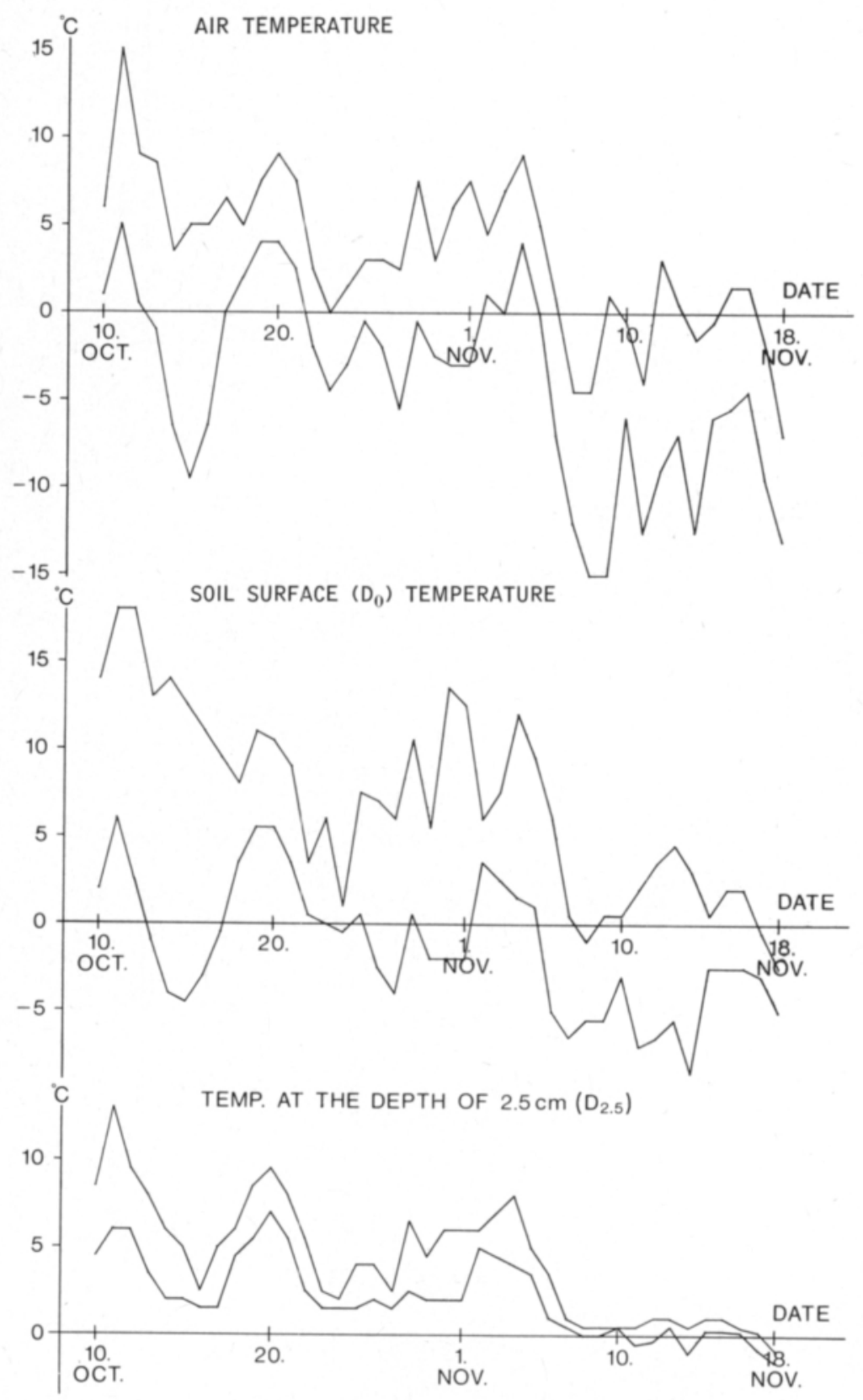

Fig. 2 a. Diurnal maximum and minimum temperatures of air, soil surface $\left(D_{0}\right)$ and the depth of $2.5 \mathrm{~cm}\left(\mathrm{D}_{2.5}\right)$ in the unploughed experimental field of Kiikala during the period of Oct. 10th to Nov. 18th, 1971. 

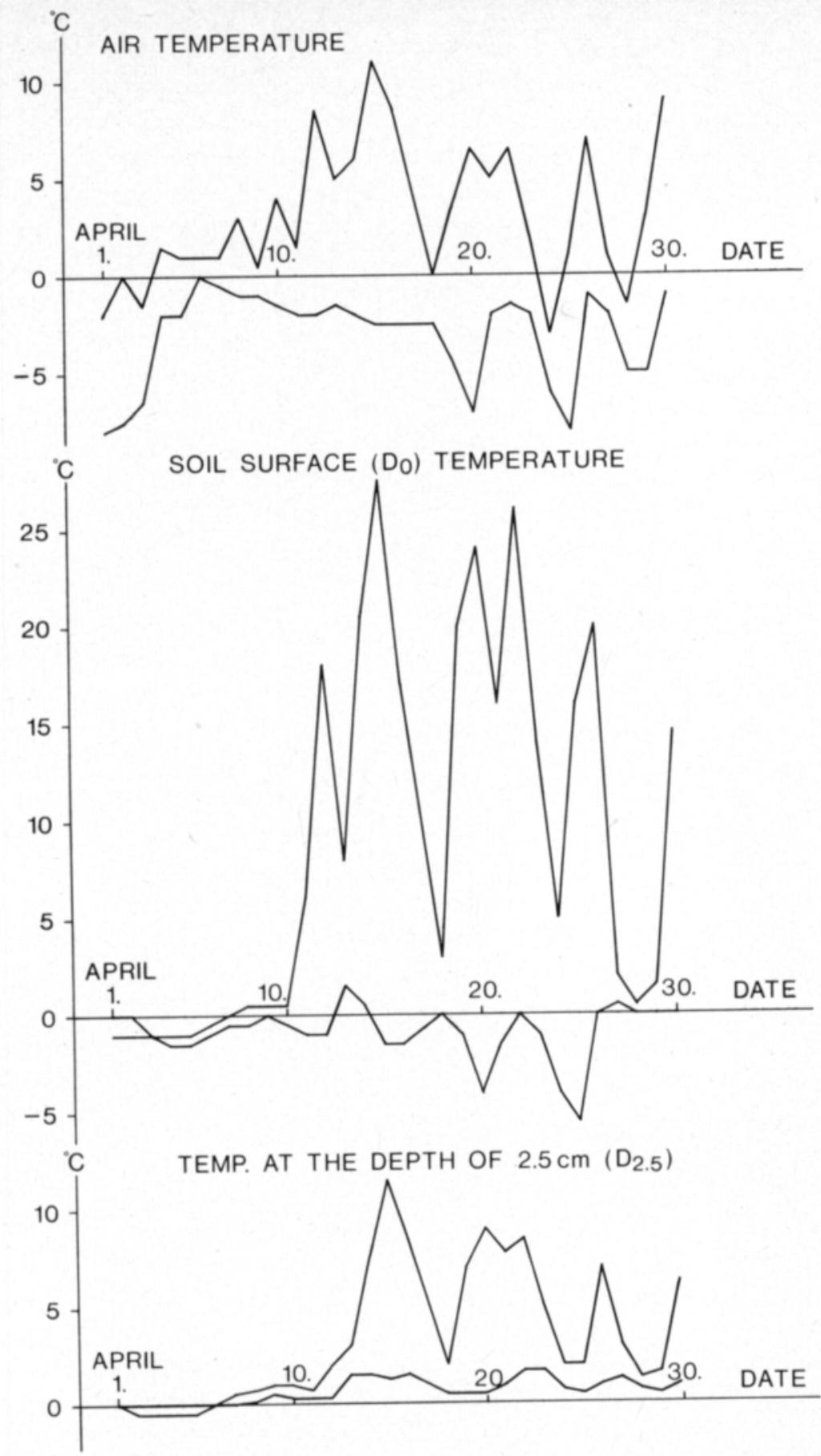

Fig. 2 b. Diurnal maximum and minimum temperatures of air, soil surface $\left(\mathrm{D}_{\mathrm{o}}\right)$ and the depth of $2.5 \mathrm{~cm}\left(\mathrm{D}_{2.5}\right)$ in the unploughed experimental field of Kiikala during the period of April 1st to April 30th, 1972. 
According to Figures $2 \mathrm{a}$ and $2 \mathrm{~b}$, the great variations of temperatures seem to be limited to a very thin soil layer on the surface. At the depth of 2.5 $\mathrm{cm}$ the greatest difference between the maximum and minimum temperatures in April was about $10^{\circ} \mathrm{C}$ (April 15th). On the same day it was on the surface $29^{\circ} \mathrm{C}$. And in spite of the temperature of air having sunk some times even below $-5^{\circ} \mathrm{C}$ after April 8 th at which time the temperature at the depth of $2.5 \mathrm{~cm}$ rose above zero, it did, however, not sink back to this temperature any more.

It is possible that the structure of the ploughed clay soil in the spring may partly be due to these variations of temperatures. This is suggested particularly by the rather thin aggregated layer on the ploughed surface; even when thickest, it hardly exeeds $1.0-1.5 \mathrm{~cm}$. But below the aggregated layer the size of the soil clods increases very quickly.

In the experimental field of $\mathrm{Helsin} \mathrm{ki}$ the temperatures in both the umploughed and the ploughed field were followed in the winter 1972-1973. Also the results of the frost depth are now given (Fig. 3). Analogically to the results of the preceding winter, the thawing of soil frost immediately affects the soil surface temperature to increase. Whether the soil was ploughed or not had no influence, but the temperatures in the ploughed and unploughed plot were with an accuracy of one degree the same from March 26th to April 28th. The soil surface thawed on March 26th and the measurements were finished April 28th. In the deeper soil layers the ploughed soil was, on the contrary, colder than the unploughed and, therefore, the thickness of the frozen layer was also in the ploughed plot greater. Evidently, this is the reason why the soil frost thawed on the whole about one week later in the ploughed plot than in the unploughed. The thinner frost layer in the unploughed plot apparently is due both to the insulating effect of the stubble itself and also to the fact that the stubble effectively keeps the snow on the soil surface.

The measurements made in $\mathrm{H}$ e $1 \mathrm{~s} \mathrm{i} \mathrm{ki}$ in the winter 1974-1975 showed clearly the effect of straw layer on the depth of frost (Fig. 4). This winter was rather mild. The average temperature of the coldest month, February, was in Helsinki $-2.0^{\circ} \mathrm{C}$. Therefore, the frost did not penetrate even in the ploughed soil very deep. Nevertheless, the effect of soil cover was clearly to be seen. Also this winter the frost penetrated deepest into the soil in the ploughed plot. When the depth was measured from a place, where in addition to the stubble also the windrow after combine was left, the depth of frost could be observed to be remarkably lower than in the ploughed plot and in the plot, where there was no windrow (cf. Andersson 1964).

The soil freezing began that winter in the ploughed plot about three weeks earlier than in the stubble plot. Between the stubble plot and the windrow plot there was a time interval of one week. But, in spite of the frost depth being the greatest in the ploughed plot, it thawed at the same time as the frost from the stubble plot, whereas the frost from the windrow plot thawed on the whole about one and a half week later though its frost depth was the lowest.

As far as soil warming is concerned, it seems that the frost depth alone is not a decisive factor, but also how effectively the soil is able to warm up, and thereafter how fast the frost thaws. If the soil is covered with some type of 

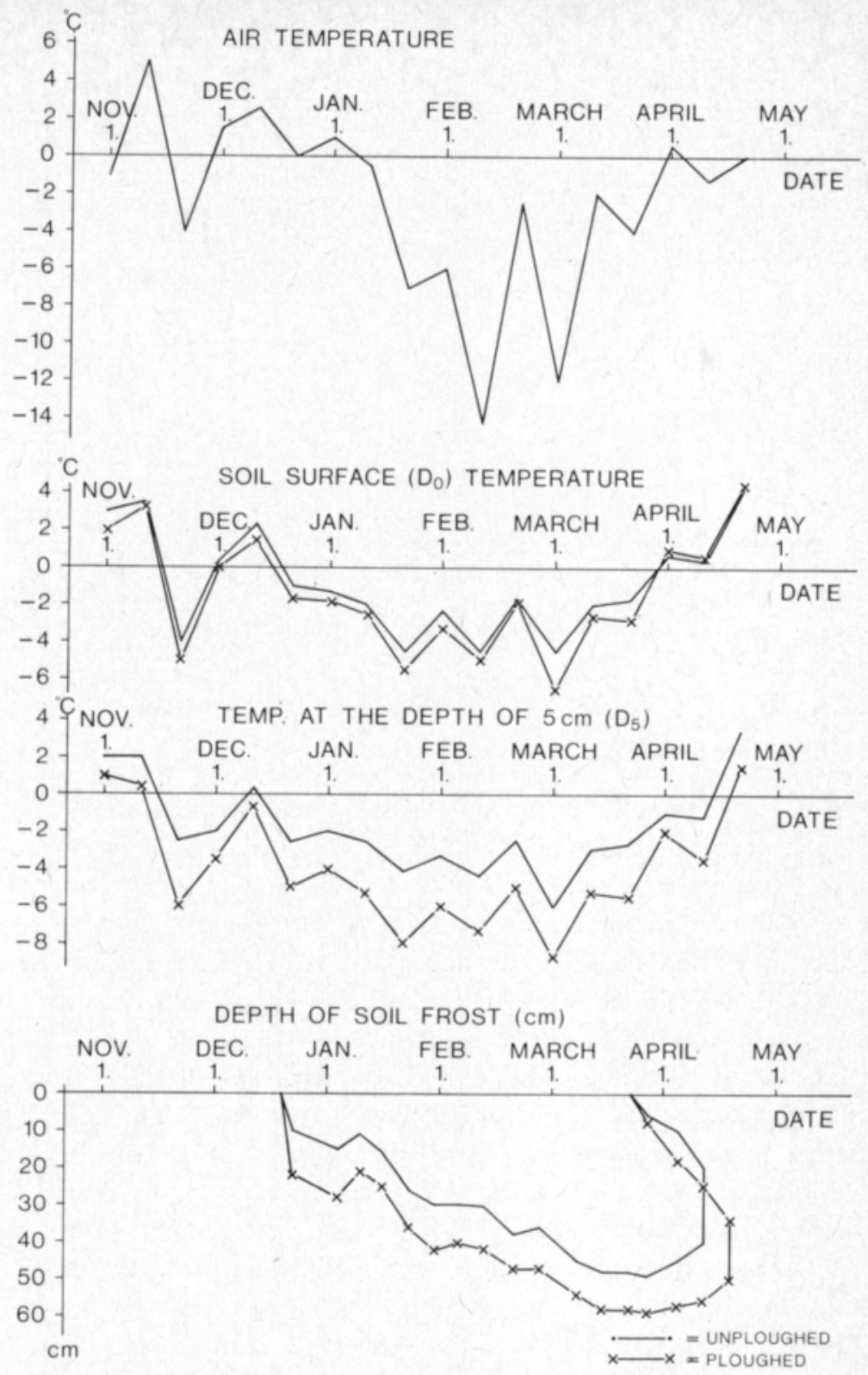

Fig. 3. Temperatures of air, soil surface $\left(D_{0}\right)$, and the depth of $5 \mathrm{~cm}$ $\left(D_{5}\right)$, the frost depth in unploughed and ploughed field in the experimental field of Helsinki during the period of Nov. 1st, 1972 to April 20th, 1973. The temperature values are calculated as in Fig. 1.

insulator it effectively prevents the heat from penetrating into the soil and, thus, makes the thawing of even a low frost layer slow. Therefore, the thawing of the frost in a ploughed field is not necessarily slower than in an unploughed field, although it may have penetrated deeper (AGERBERG 1948). 


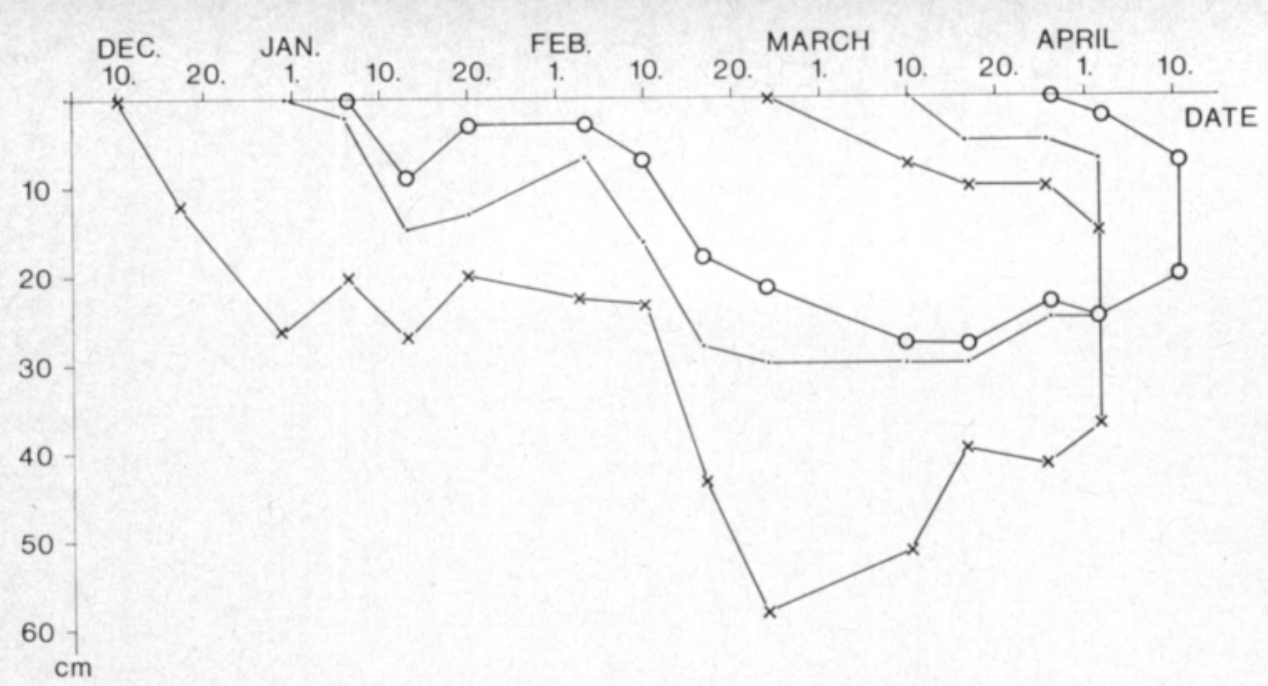

Fig. 4. Depths of soil frost $(\mathrm{cm})$ in the experimental field of Helsinki during the winter 1974-1975. $\mathrm{x}-\mathrm{x}$ indicates depth of frost in ploughed field, . - . in unploughed field, and $\mathrm{o}-\mathrm{o}$ in unploughed field, beneath a straw layer, $20 \mathrm{~cm}$ in thickness.

\section{Field tillage observations}

It is probable that in determining the soil structure and particularly that of seedbed the depth of frost has a minor effect on it. The structural changes which are important for tillering will take place primarily on the top of the soil and only few drastic changes take place in the deeper soil layers.

The rains and wind strive to even up the rough field surface caused by ploughing. Both in the $\mathrm{Kiikala}$ and $\mathrm{Helsinki}$ experimental fields a simple experiment was set up in the winter 1974-1975 to follow the changing of the surface profile of the ploughed field (Fig. 5). The distance from the soil surface to a horizontal slab above the soil was measured. The sharpest edges of the furrows have become clearly smoother, whereas the holes between the furrows are filled. The effect of the winter apparently is, however, not only limited to the smoothing effect of the very surface, but the water formed by thawing transports some soil material to deeper layers, too. Some of the soil material movement probably takes place also by rolling (HENRIKSSON 1971). The levelling of the ploughed soil surface thus causes the large holes to be filled in the ploughing layer and remarkably change the porosity properties during the winter.

To inspect the effects of different coverings on the tillage properties of soil, a field trial was set up in the winter $1977-1978$ in the $\mathrm{Helsinki}$ experimental field. In this trial, an area of $6.8 \times 9.5 \mathrm{~m}^{2}$ was divided into 16 experimental plots. The trial consisted of four different treatments which were: i) a normal ploughed field, ii) a normal ploughed field, but the snow was removed during the winter, iii) the ploughed field was covered in the autumn with a transparent plastic iv) the ploughed field was covered in the autumn with a straw layer of $15 \mathrm{~cm}$ in thickness. The depth of soil frost and the temperatures were not followed in this experiment. 

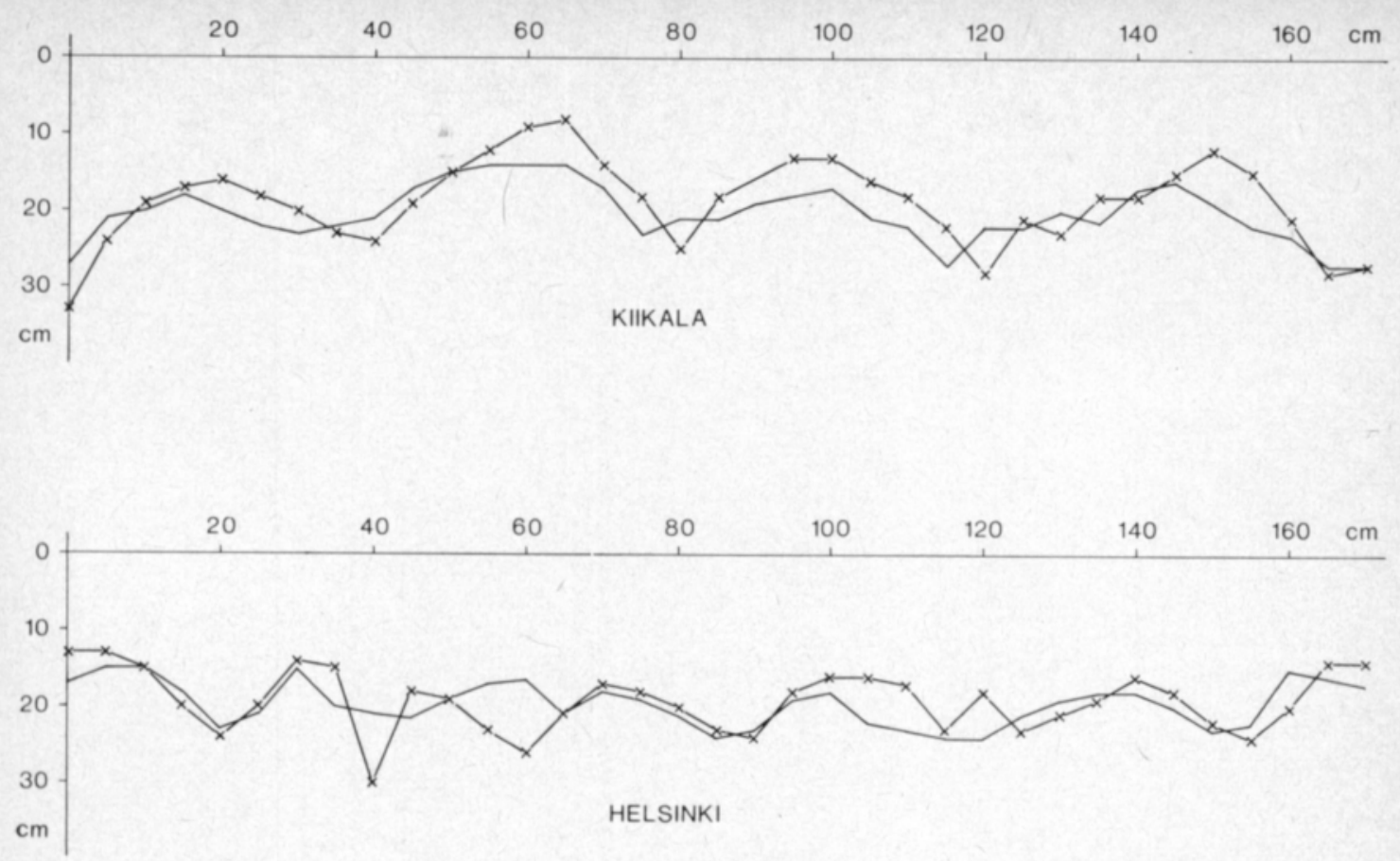

Fig. 5. Horizontal profile of ploughed experimental fields of Kiikala and Helsinki in the autumn $1974(\mathrm{x}-\mathrm{x})$ and spring $1975(-)$.

In the autumn about $250 \mathrm{~g}$ of soil was taken from each experimental plot and let to dry at room temperature. The soil samples were taken from plough layer. The same amount of soil was taken also in the spring immediately before the tillering was started and it was also let to dry at room temperature. The dry soils were broken by hand as cautiously as possible to pass a $20 \mathrm{~mm}$ sieve. From each lot $50 \mathrm{~g}$ was taken for a dry sieving analysis. The procedure was equal to that used later in this work (p. 270).

When the percentage proportion of the total soil content sieved of the aggregate size fraction $<1 \mathrm{~mm}$ is the criterion of the hardness of the soil, the following results were acquired ( $v$ represents the samples taken in the autumn):

$\begin{array}{ccccc}\mathrm{i} & \text { ii } & \text { iii } & \text { iv } & \text { v } \\ 20.2^{\mathrm{e}} & 20.6^{\mathrm{c}} & 34.7^{\mathrm{b}} & 33.0^{\mathrm{b}} & \left.40.0^{\mathrm{a}}{ }^{*}\right)\end{array}$

*) Means followed by a common letter do not differ at $\mathrm{P}=0.05$.

The samples collected in the autumn have broken down to a significantly smaller extent than those taken in the spring. The results clearly show also that the coverings only have had a negative effect on the soil as far as aggregated structure is concerned. The covers also made both the thawing of the frost and, naturally, the drying of the soil slower. In all the experimental plots covered with straw, there still was on May 10th, which was the time tillering was started, some ice on the soil surface. It seems thus that the treatment where no special procedures were applied had the most beneficial effect on the soil structure. 


\section{Effect of freezing in field and laboratory on soil water retention}

In connection with the field experiment in $\mathrm{Helsinki}$ in the winter 1974-1975 when the deformation of the profile of ploughed field was followed, a series of undisturbed soil samples was also collected. The purpose of these samples was to study, whether it was possible to find the same effects on the soil by freezing in the laboratory as by natural freezing in the field. It was supposed that the changes caused in the soil structure in the field probably would be seen in the water retention properties.

The procedure of the experiment was as follows:

Forty-two cylindrical soil samples were collected from an area of $1 \times 1 \mathrm{~m}^{2}$ in the autumn 1974. The field was unploughed. The size of samples was $100 \mathrm{ml}, 5,3 \mathrm{~cm}$ in diameter, and they were taken from the depth of $0-5 \mathrm{~cm}$. The samples were treated for the water retention analyses with the following procedures:

1. Determination of the water retention curve immediately after the uptake.

2. Freezing in the laboratory:

a. Freezing at the water potential of -0.06 bar and at the temperature of $-5^{\circ} \mathrm{C}$.

b. Freezing at the water potential of -0.06 bar and at the temperature of $-15^{\circ} \mathrm{C}$.

c. Freezing at the water potential of -0.34 bar and at the temperature of $-5^{\circ} \mathrm{C}$.

d. Freezing at the water potential of -0.34 bar and at the temperature of $-15^{\circ} \mathrm{C}$.

3. Wetting and drying at room temperature.

In addition, some of the samples were kept in the field during the winter, either in an open box or in a half closed box.

The samples (1) were moistened with the capillary procedure of HARTGE (1965) on a wet foamy plastic to the water potential of -0.001 bar. The wetting time was three weeks. The water retention curve was determined thereafter with the pressure procedure of RICHARDS (1948).

The samples (2) were first moistened to the potential of -0.001 bar and dried thereafter in the pressure chamber on ceramic plates to the potential decided. After equilibrium the samples were brought to the freezing temperature. In order to prevent sublimation they were sealed with a plastic cover. After a 3.5 -day freezing period the samples were brought to the temperature of $+5^{\circ} \mathrm{C}$ and let to thaw for another 3.5 days. This procedure was repeated 15 times and the water retention curve was determined thereafter.

The samples (3) were first let to dry at room temperature until they were air dry. Thereafter they were moistened with the method described above to the potential of -0.001 bar. The moistening time was 3.5 days taking place at the temperature $+5^{\circ} \mathrm{C}$. The subsequent drying period lasted another 3.5 days and was performed at room temperature. This moisteningdrying procedure, too, was repeated 15 times, before the determination of water retention curve.

The samples kept in the field during the winter were put into the Büchner funnels, ca. $14 \mathrm{~cm}$ in diameter. The funnels were placed on the soil surface and half filled with coarse gravel to ensure escape of excess water. Half of the samples were covered with a wide plastic cylinder with several holes all over. The purpose of these holes was to make possible the free air movement around the sample. The other half of the samples were left in the funnels as such without any cover and it was thus possible that the rain hurt them. These samples were not taken into consideration when determining the water retention properties, because some of them, particularly those kept in the closed plastic cylinders, were so fragile that breakdown was impossible to avoid.

In the spring 1975 new samples were taken from the same field to compare the effects of winter with the artificial treatments described above. For some of these samples the water retention curve was determined immediately after the samples were brought from the field and moistened to the potential of -0.001 bar (treatment 4 a). The rest were first let to dry 
at room temperature until they were air dry and thereafter moistened to the same potentia for the water retention curve determination (treatment $4 \mathrm{~b}$ ).

Contrary to expectations, both the winter and the laboratory treatments have diminished throughout the water contents retained at different soil moisture potentials (Table 1). The untreated samples taken in the autumn have retained significantly more water than any other samples. The samples taken in the spring, instead, seem to have retained about the same amount of water as those frozen or wetted-dried in the laboratory. On the whole, it seems that the samples frozen at a higher water potential ( $2 \mathrm{a}$ and $2 \mathrm{~b}$ ) have retained slightly more water than those frozen at a lower water potential $(2 \mathrm{c}$ and $2 \mathrm{~d})$. The treatment (3) (wetting-drying) resembles those where freezing has taken place at a lower water potential.

Table 1. Soil moisture contents $(\%, w / w)$ of the cylindrical samples taken from the experimental field of Helsinki at different soil water potentials (bar) after different freezing treatments.

\begin{tabular}{cccccc}
\hline Treatment & -0.001 & -0.01 & -0.02 & -0.1 & $-1.0^{\circ}$ \\
\hline & & & & & \\
1 & $34.8^{\mathrm{a}}$ & $32.6^{\mathrm{a}}$ & $31.6^{\mathrm{a}}$ & $29.1^{\mathrm{a}}$ & $26.6^{\mathrm{a}}$ \\
$2 \mathrm{a}$ & $32.4^{\mathrm{b}}$ & $30.7^{\mathrm{b}}$ & $30.3^{\mathrm{b}}$ & $27.9^{\mathrm{b}}$ & $25.0^{\mathrm{b}}$ \\
$2 \mathrm{~b}$ & $32.4^{\mathrm{b}}$ & $30.6^{\mathrm{b}}$ & $30.1^{\mathrm{b}}$ & $27.6^{\mathrm{b}}$ & $25.0^{\mathrm{bc}}$ \\
$2 \mathrm{c}$ & $32.1^{\mathrm{b}}$ & $28.6^{\mathrm{cd}}$ & $28.5^{\mathrm{ed}}$ & $26.6^{\mathrm{c}}$ & $24.5^{\mathrm{bc}}$ \\
$2 \mathrm{~d}$ & $31.7^{\mathrm{b}}$ & $29.2^{\mathrm{c}}$ & $28.3^{\mathrm{d}}$ & $26.4^{\mathrm{e}}$ & $24.4^{\mathrm{b}}$ \\
3 & $29.1^{\mathrm{e}}$ & $27.7^{\mathrm{d}}$ & $27.6^{\mathrm{d}}$ & $26.0^{\mathrm{c}}$ & $23.1^{\mathrm{d}}$ \\
$4 \mathrm{a}$ & $29.8^{\mathrm{c}}$ & $28.9^{\mathrm{ed}}$ & $28.3^{\mathrm{d}}$ & $26.0^{\mathrm{c}}$ & $24.0^{\mathrm{c}}$ \\
$4 \mathrm{~b}$ & $31.4^{\mathrm{b}}$ & $30.2^{\mathrm{b}}$ & $29.5^{\mathrm{b}}$ & $26.6^{\mathrm{c}}$ & $24.0^{\mathrm{c}}$ \\
\hline
\end{tabular}

(treatments: see the text)

Means in each column followed by a common letter do not differ at $\mathrm{P}=0.05$.

The effects of freezing temperatures on the water retention properties were similar at both moisture levels.

If the retained water contents are expressed as volume percentages $(v / v)$, the basis of the volume being in this case the volume of the sample at the moment of taking, the order of magnitude of the figures will change (Table 2). The water contents of the samples taken in the spring seem to have been almost in every case greater than those of the autumn samples. This is natural as the spring samples were at the moment of taking significantly drier than those taken in the autumn (moisture content of the spring samples was $19 \%$ and the autumn samples $50 \%$ ). Thus their weights of volume were quite different, too: 1.39 and 1.20 respectively. The order of magnitude of the water retention effectiveness of the samples taken in the autumn has not changed from those given in Table 1.

A general tendency seems to have been that neither the wetting-drying treatments nor the freezing treatments have increased the amounts of water the soil is able to retain at the potentials studied. The amount has rather diminished. But, on the other hand, the diminishing of the water content has 
Table 2. Soil moisture contents $(\%, v / v)$ and air spaces (volume- $\%)$ of the cylindrical samples taken from the experimental field of Helsinki at different soil water potentials (bar) after different freezing treatments.

\begin{tabular}{|c|c|c|c|c|}
\hline \multirow{2}{*}{ Treatment } & -0.001 & -0.02 & -0.1 & -1.0 \\
\hline & \multicolumn{4}{|c|}{ Soil moisture content $(\%, v / v)$} \\
\hline 1 & $41.8^{\mathrm{ab}}$ & $37.9^{\mathrm{b}}$ & $34.9^{\mathrm{b}}$ & $31.9^{\mathrm{a}}$ \\
\hline $2 \mathrm{~b}$ & $38.9^{\mathrm{bc}}$ & $36.1^{\mathrm{e}}$ & $33.1^{\mathrm{c}}$ & $30.0^{\mathrm{b}}$ \\
\hline $2 d$ & $38.0^{\circ}$ & $34.0^{\mathrm{d}}$ & $31.7^{\mathrm{d}}$ & $29.3^{\text {be }}$ \\
\hline 3 & $34.9^{d}$ & $33.1^{\mathrm{d}}$ & $31.2^{\mathrm{d}}$ & $27.7^{\mathrm{e}}$ \\
\hline $4 a$ & $41.4^{b}$ & $39.3^{b}$ & $36.1^{\mathrm{a}}$ & $33.4 \mathrm{~s}$ \\
\hline \multirow[t]{2}{*}{$4 \mathrm{~b}$} & $44.3^{\mathrm{a}}$ & $41.8^{\mathrm{a}}$ & $37.4^{\mathrm{a}}$ & $33.4^{\mathrm{a}}$ \\
\hline & \multicolumn{4}{|c|}{ Air volume ( $\%$ of vol.) } \\
\hline 1 & $13.0^{\mathrm{b}}$ & $16.9^{\mathrm{a}}$ & $19.9^{\mathrm{a}}$ & $22.9^{\mathrm{ab}}$ \\
\hline $2 \mathrm{~b}$ & $16.5^{\mathrm{ab}}$ & $19.3^{\mathrm{a}}$ & $22.3^{\mathrm{a}}$ & $25.4^{\mathrm{ab}}$ \\
\hline $2 d$ & $15.7^{\mathrm{ab}}$ & $19.7^{\mathrm{a}}$ & $22.0^{\mathrm{a}}$ & $24.4^{\mathrm{ab}}$ \\
\hline 3 & $20.0^{\mathrm{a}}$ & $21.8^{\mathrm{a}}$ & $23.7^{\mathrm{a}}$ & $27.2^{\mathrm{a}}$ \\
\hline $4 a$ & $6.1^{\mathrm{e}}$ & $15.6^{\mathrm{a}}$ & $18.8^{\mathrm{a}}$ & $21.5^{b}$ \\
\hline $4 \mathrm{~b}$ & $5.7^{\mathrm{e}}$ & $8.2^{\mathrm{b}}$ & $12.6^{\mathrm{b}}$ & $16.6^{\mathrm{e}}$ \\
\hline
\end{tabular}

(treatments: see the text)

Means in each column followed by a common letter do not differ at $\mathrm{P}=0.05$.

increased the air volume in the sample (Table 2). The samples taken in the autumn and frozen or wetted-dried seem to have had a slightly larger air volume than the untreated samples (1). In practice this apparently means that some fissures are formed into the samples because of the effects of the treatments and they are not capable of retaining water even at the highest water potentials. In other words, this would mean that the soil structure had improved, as far as the air volume is concerned.

The air volume of the samples taken in the spring has been, particularly at the highest water potentials, remarkably lower than of those taken in the autumn, this being generally due to the volume changes of the soil. This would mean that the structural properties, instead of improving during the winter, get worse. It is probable that the volume changes due to the water content to some degree, at least, eliminate the structural changes that take place in the soil because of freezing. Another factor connected with this, also acting as an eliminating agent, is the water formation as a result of thawing of ice. The mutual effect of these two factors can be seen from the figures of the treatments $4 \mathrm{a}$ and $4 \mathrm{~b}$. If the sample taken in the spring was let to dry (4 b) before the determination of the water retention curve, its air volume would remain smaller than that of the samples 4 a, where the water retention curve was determined immediately after the samples were taken.

The dissipating effect of excessive amount of water, either as a result of thawing or added afterwards, could be seen in the samples kept in the field during the winter. The fragility, particularly of those kept in closed plastic 
cylinders, indicated that the effects of freezing may be extremely clear if the effects of rain and excess water are eliminated. According to this, it can be expected a reason for the results to be the processes taking place in a closed system (TABER 1930). This makes it possible for the thawing water to eliminate the cleaves formed by freezing. 


\section{Studies in the laboratory with collected samples}

\section{Research material}

In the autumn 1973 several soil samples were collected from the south of Finland for laboratory analyses. After preliminary analyses, eight samples were chosen for the proper analyses. Each of these eight samples was taken from the plough layer. All except one were from a field where some type of cereal was grown in the preceding summer. One sample was from a sugar beet field.

\section{Selection of samples}

An essential criterion for the selection of samples was to find for the analyses soils in which the structural effect of freezing would be obvious. Therefore, these eight samples do not contain any bog soils or any sandy and fine sandy soils. Another criterion was to find samples which would make it possible to compare the effects of freezing between two different soil types. As a result, two soil type groups were decided to be taken for the analyses, one with a high clay content and the other with a lower clay content but a rather high silt fraction content.

In the very beginning of this study it became evident that the analyses are very laborous and time-consuming. Therefore the number of samples for the analyses had to be restricted and, as a consequense, their number is limited to eight, which allows some comparative analysis between the two soil type groups.

2. Collection of samples and primary analyses

The samples were collected into big plastic bags and let to incubate in those bags for one month at room temperature. After incubation they were taken out as big clods and slowly let to dry. After drying the clods were broken to pass a $10 \mathrm{~mm}$ sieve. The primary chemical and physical analyses were made with this broken material. The following methods of analysis were used:

The organic carbon content was estimated by wet combustion (Graham 1948).

The $p H$ of the soils was measured in a $0.01 \mathrm{M} \mathrm{CaCl}_{2}$ suspension (RYTI 1964).

The particle density was determined by the pycnometer method keeping the soil for a short time in gently boiling distilled water (BLAKE 1965 b).

Particle size analysis was made by the pipette procedure developed by Elonen (1971).

The water retention curves (Fig. 6) were determined by the pressure procedure. The water contents at the soil moisture potentials of -0.01 to -3.2 bar were determined by the ceramic 
plate method of RichaRds (1948). The water contents at the potentials of -7.9 to -15.0 bar were determined from suspension by the pressure membrane method (RicHARDs 1949) after the soil was submerged for three weeks (HEINONEN 1961). The wetting procedure before the determination of the water contents at higher water potentials was the capillary procedure of HaRtge (1965).

In order to compare the means of the results obtained, Duncan's (1955) test was applied at the 95 percent confidence level. Significant differences between the quantities reported in the tables as means of the treatment replications are marked down as the upper index letters of each quantity. Those quantities that do not have the same letter in the upper index deviate from each other at a confidence level of 95 percent. The quantities compared are marked down in each table tested by the Duncan method.

\section{Classification of samples}

The eight soil samples were divided into two soil type groups primarily for the comparative inspection of the results. The four samples, where the clay fraction content was above $60 \%$, are called in this study heavy clay soils (C-samples). In the other group (S-samples) the clay fraction content ranges from 35 to $42 \%$. These samples are called silty clay soils. Furthermore, in each group the samples are numbered from 1 to 4 according to the increasing amount of organic carbon.

When comparing the mutual properties of the heavy clay samples, one can see that the clay contents of the samples $\mathrm{C} 1$ and $\mathrm{C} 4$ are quite similar (Table $3)$, but the organic carbon contents differ. On the other hand, the organic carbon contents of the samples C 2 and C 3 are similar, while the clay contents differ. All except C 2 are quite acid soils. The sample C 2 is taken from a sugar beet field.

Table 3. Characteristics of experimental soils.

\begin{tabular}{cccccrrrr}
\hline $\begin{array}{c}\text { Sample } \\
\text { No. }\end{array}$ & $\begin{array}{c}\text { Org. C } \\
\%\end{array}$ & $\mathrm{pH}$ & $\begin{array}{c}\text { Particle } \\
\text { density }\end{array}$ & \multicolumn{5}{c}{ Particle size fraction $(\mu \mathrm{m}) \%$} \\
\hline & & & & $2-6$ & $6-20$ & $20-200$ & $>200$ \\
\hline C 1 & 2.5 & 5.5 & 2.69 & 68 & 10 & 8 & 9 & 5 \\
C 2 & 4.4 & 6.9 & 2.62 & 62 & 13 & 11 & 12 & 2 \\
C 3 & 4.9 & 5.2 & 2.66 & 75 & 7 & 4 & 10 & 4 \\
C 4 & 6.7 & 4.9 & 2.57 & 72 & 8 & 7 & 8 & 5 \\
& & & & & & & & \\
S 1 & 3.3 & 5.2 & 2.71 & 33 & 32 & 20 & 12 & 3 \\
S 2 & 3.7 & 5.0 & 2.65 & 34 & 33 & 20 & 11 & 2 \\
S 3 & 6.3 & 6.4 & 2.62 & 45 & 33 & 11 & 6 & 5 \\
S 4 & 7.8 & 4.6 & 2.48 & 33 & 30 & 20 & 12 & 5 \\
\hline
\end{tabular}

Of the silty clay samples $\mathrm{S} 3$ has the highest clay content and its $\mathrm{pH}$ is also the highest. All the other samples have a very similar clay content. The samples S 1 and S 2 contain quite a small amount of organic carbon, whereas S 3 and $\mathrm{S} 4$ are rich in organic carbon. 
to study the effects of freezing on disturbed samples. Therefore, two different experiments were set up. The purpose of these experiments was to check, whether the effects of freezing and wetting-drying treatments were similar to those described above when the natural structure of the soil has been disturbed. In the first test the soils were suspended and the treatments employed were freezing and wetting-drying. In the second test the soils were only ground.

1. Effect of freezing and wetting-drying treat ment on water retention of suspended soils

The experiment procedure was as follows:

Six hundred grams of air dry soil was thoroughly suspended with $600 \mathrm{ml}$ of water by mixing with a glass rod. The suspension was allowed to stand for one day before pouring it on a sintered glass filter (pore size G 4). The height of water head was established to respect the moisture potentials of -0.01 bar and -0.1 bar respectively. The method was equal to that of AURA (1975). The sample was let to stand on the filter until equilibrium was reached. For the silty clay samples the time was about one and a half days and for the heavy clay samples three to five days. During this time the soils were covered with a piece of plastic to prevent evaporation.

When equilibrium was reached, soil slices $1 \mathrm{~cm}$ in thickness and $3 \times 3 \mathrm{~cm}^{2}$ in area were cut from the soil on the filter and these slices were used for the treatments.

\section{The treatments were the following:}

1. Determination of the water retention curve of untreated slice.

2. Wetting-drying treatment. The slice was wetted on foamy plastic to the water potential of -0.001 bar. The wetting time was 3.5 days after which the soil was allowed to dry at room temperature for another 3.5 days. The procedure was repeated five times.

3. Freezing treatments at the water potentials of -0.01 and -0.1 bar. The freezing temperatures were $-5^{\circ},-15^{\circ},-25^{\circ}$, and $-35^{\circ} \mathrm{C}$. The length of the freezing period was 3.5 days, after which the samples were brought to thaw at the temperature of $+5^{\circ} \mathrm{C}$ for 3.5 days. To prevent evaporation, the freezing boxes were closed during the freezing. The number of cycles was also five.

After treatments 2 and 3 the slices were put on foamy plastic for three days for moistening to the potential of -0.001 bar. The water retention curve was determined thereafter.

The water retention curves ranged from -0.01 bar to $-1.0 \mathrm{bar}$, but the results given in Table 4 represent only those of -0.02 bar and -0.1 bar. The differences between the results of different treatments were no more significant at lower water potentials, but the changes appearing in the samples as a result of the treatments are perceptible only at rather high water potentials. This result seems therefore to be in good accordance with the results recieved from the undisturbed samples.

Analogical to the former results are also those where the water contents almost regularly seem to have diminished because of freezing or wetting-drying treatments as compared to the untreated samples. The effects of freezing temperatures have been also very similar in both soil type groups in spite of these being fairly different. The results of the freezing treatments in Table 4 
Table 4. Soil moisture contents $(\%, w / w)$ of the suspended soil samples at the soil water potentials of -0.02 and -0.1 bar after five cycles of freezing $\left(-5^{\circ} \mathrm{C}\right)$ or wetting-drying $(\mathrm{w}-\mathrm{d})$ treatments. The freezing procedures were performed at the water potential of -0.1 bar. $\mathrm{O}=$ untreated sample.

\begin{tabular}{|c|c|c|c|c|c|c|}
\hline \multirow{2}{*}{ Sample } & \multicolumn{3}{|c|}{-0.02} & \multicolumn{3}{|c|}{-0.1} \\
\hline & 0 & $w-d$ & $-5^{\circ} \mathrm{C}$ & 0 & $w-d$ & $-5^{\circ} \mathrm{C}$ \\
\hline C 1 & $47.0^{\mathrm{a}}$ & $45.3^{\mathrm{ab}}$ & $42.6^{b}$ & $43.8^{\mathrm{a}}$ & $40.4^{b}$ & $40.1^{\mathrm{b}}$ \\
\hline C 2 & $52.5^{\mathrm{a}}$ & $50.0^{\mathrm{ab}}$ & $48.4^{b}$ & $50.0^{\mathrm{a}}$ & $46.4^{b}$ & $46.1^{\mathrm{b}}$ \\
\hline C 3 & $52.8^{\mathrm{a}}$ & $51.2^{\mathrm{a}}$ & $50.4^{\mathrm{a}}$ & $49.3^{\mathrm{a}}$ & $48.3^{\mathrm{a}}$ & $48.3^{\mathrm{a}}$ \\
\hline C 4 & $68.7^{\mathrm{a}}$ & $62.7^{\mathrm{ab}}$ & $59.4^{\mathrm{b}}$ & $62.8^{\mathrm{a}}$ & $53.2^{\mathrm{b}}$ & $50.9^{\mathrm{b}}$ \\
\hline S 1 & $44.2^{\mathrm{a}}$ & $42.3^{\mathrm{ab}}$ & $39.6^{b}$ & $42.0^{\mathrm{a}}$ & $39.0^{\mathrm{b}}$ & $37.8^{b}$ \\
\hline $\mathrm{S} 2$ & $48.7^{\mathrm{a}}$ & $46.7^{b}$ & $43.8^{\mathrm{e}}$ & $45.0^{\mathrm{a}}$ & $45.2^{\mathrm{a}}$ & $42.1^{\mathrm{b}}$ \\
\hline S 3 & $54.6^{\mathrm{a}}$ & $49.8^{\mathrm{b}}$ & $45.3^{\mathrm{b}}$ & $51.2^{\mathrm{a}}$ & $47.1^{\mathrm{b}}$ & $43.2^{\mathrm{b}}$ \\
\hline $\mathrm{S} 4$ & $54.3^{\mathrm{ab}}$ & $55.8^{\mathrm{a}}$ & $52.6^{\mathrm{b}}$ & $51.5^{\mathrm{ab}}$ & $52.2^{\mathrm{a}}$ & $50.0^{\mathrm{b}}$ \\
\hline
\end{tabular}

Means in each line under the same water potential followed by a common letter do not differ at $\mathrm{P}=0.05$.

are therefore from the $-5^{\circ} \mathrm{C}$ freezing only, because it most likely represents the temperature existing in the field in winter. Neither have the moisture potentials had different effects on the water contents retained at the given water potentials. Therefore the results are given only for the $-0.1 \mathrm{bar}$.

The result seems thus to be that the freezing and the wetting-drying treatments have caused the soil to lose its capability to retain water at high water potentials. The results show a slight tendency the freezing treatments to be in this sense a little more effective, particularly at the potential of -0.02 bar, but the differences are in most cases statistically insignificant.

Reduction of the water contents as a concequence of the treatments is well understandable in this experiment. The wet soil on the sintered glass filter the soil slices were cut from was rather loose, even after the equilibrium. Therefore, the positioning of the individual soil particles may have been in certain degree instabile. Both of the processes apparently have disturbed this instability and, as a consequence, the particles have moved tighter together. This means that the soil has become more dense, but on the whole this more probably means formation of larger cleaves not capable to retain water but filled with air. Those cleaves were in fact to be seen in these soil slices and more in the frozen than the wetted-dried specimens.

\section{Effect of freezing on water retention of fine ground soils}

The aim of this test was to find out, whether the water retention properties of ground soils differ from those of suspended soils as far as the effects of different freezing treatments are concerned. Partly this test was similar to that dealt with in the previous chapter, but in addition the effect of the freezing cycles was studied, not the effect of wetting-drying treatment. 
The experiment procedure was as follows:

Fifty grams of air dry soil ground to pass a 2-mm sieve was taken for each treatment. One third was poured into a $100 \mathrm{ml}$ metal cylinder (53 $\mathrm{mm}$ in diameter). One third of the amount of the water needed for the soil water potential of -0.06 bar was dropped on the soil. The water was spread as evenly as possible all over the soil. Another third of the soil content was put into the cylinder and the corresponding amount of water. This was repeated once more. The cylinder was covered to prevent evaporation and the moisture was allowed to reach equilibrium for one day at room temperature.

After one day the samples were compacted with a pressure of 0.5 bar to ensure a structure as homogenous as possible and allowed to stand thereafter for another two days at room temperature before the freezing treatments were started.

The freezing temperatures were $-5^{\circ},-15^{\circ},-25^{\circ}$, and $-35^{\circ} \mathrm{C}$. The moisture content at freezing respected the water potential of -0.06 bar. The freezing treatments were:

1. Three and a half days in a freezing chamber and another 3.5 days in $\mathrm{a}+5^{\circ} \mathrm{C}$ room for thawing.

2. The same as treatment 1 , but the number of cycles was 5 .

3. The same as treatment 1 ., but the number of cycles was 15 .

In all cases the treatments took place in tightly closed cylinders. After the last thawing the cylinders were placed on foamy plastic to get moistened. The water retention curve was determined thereafter.

As was the case with soil suspensions, the effects of freezing on the water retention properties appeared also in the ground soil samples only at rather high soil water potentials. Therefore, because the results for -0.01 and -0.02 bar were analogous to those of $-0.1 \mathrm{bar}$, the numerical results have been presented only for the latter (Table 5). No significant differences between

Table 5. Soil moisture contents $(\%, w / w)$ of ground samples at the soil water potential of -0.1 bar after zero (0), one (1), five (5) and fifteen (15) freezing cycles at $-5^{\circ} \mathrm{C}$.

\begin{tabular}{ccccc}
\hline Soil sample & 0 & 1 & 5 & 15 \\
\hline C 1 & $42.4^{\mathrm{a}}$ & $40.5^{\mathrm{b}}$ & $39.3^{\mathrm{e}}$ & $37.8^{\mathrm{d}}$ \\
C 2 & $48.3^{\mathrm{a}}$ & $45.8^{\mathrm{b}}$ & $44.6^{\mathrm{e}}$ & $44.4^{\mathrm{e}}$ \\
C 3 & $52.5^{\mathrm{a}}$ & $49.8^{\mathrm{b}}$ & $48.1^{\mathrm{e}}$ & $47.6^{\mathrm{d}}$ \\
C 4 & $52.0^{\mathrm{a}}$ & $49.4^{\mathrm{b}}$ & $47.9^{\mathrm{e}}$ & $47.2^{\mathrm{c}}$ \\
& & & & \\
S 1 & $40.6^{\mathrm{a}}$ & $39.4^{\mathrm{b}}$ & $37.9^{\mathrm{e}}$ & $36.7^{\mathrm{a}}$ \\
S 2 & $45.5^{\mathrm{a}}$ & $44.6^{\mathrm{b}}$ & $42.6^{\mathrm{e}}$ & $40.9^{\mathrm{d}}$ \\
S 3 & $51.8^{\mathrm{a}}$ & $49.9^{\mathrm{b}}$ & $47.7^{\mathrm{e}}$ & $46.2^{\mathrm{d}}$ \\
S 4 & $58.6^{\mathrm{a}}$ & $54.5^{\mathrm{b}}$ & $51.3^{\mathrm{e}}$ & $44.5^{\mathrm{d}}$ \\
\hline
\end{tabular}

Means in each line followed by a common letter do not differ at $\mathrm{P}=0.05$.

the effects of different temperatures could be observed and the results in Table 5 thus show only those of $-5^{\circ} \mathrm{C}$.

Also in this test the percentage of water content at the water potentials given was without any exception diminished as a result of freezing when compared with the water contents of specimens not frozen. The diminishing 
seems to be more effective as the number of freezing cycles increases. There still exist significant differences between the water contents of samples after five and fifteen freezing cycles.

Because it was not possible within these measurements to measure the air volumes of the samples, it cannot be said with certainty, whether the total pore volume has increased or not. The small fissures on the surface of the specimens after the treatments indicate, however, like in the test with soil suspensions that some compaction had taken place. This would thus mean that a certain degree of increase of air volume due to freezing is possible. The fact that the fissures were not so large as those in suspensions apparently is a consequence of the compaction of 0.5 bar. After compaction the soil particles have probably not been in as instabile a position as before and thus the mutual movement of soil particles taken place as the consequence of the formation of ice has been smaller than in soils as suspensions. The figures in Table 5 being smaller in general than the corresponding figures in Table 4, apparently is also due to compaction.

\section{Effect of freezing on the stability of soil aggregates}

The measurements in the field showed that the very surface of the soil is subjected to the strongest effects of rains and changes of temperatures. The compactness of soil surface, consisting particularly in the autumn clods, crumbs and aggregates of very different sizes, therefore determines the soil surface structure as caused by the above factors. For this reason it was wellfounded to study the resistance of the aggregates to stability tests after different freezing treatments.

The most common methods for measuring aggregate stability obviously are the different sieving methods, i.e. wet sieving and dry sieving. When studying the effects of freezing by employing these procedures, the result usually has been a weakening of the aggregates because of the freezing treatments. In those studies the soil has normally first been moistened to a certain soil moisture content and thereafter frozen at a certain temperature once or several times. E.g. Slater and Hopp (1949) moistened the soil to three different moisture contents. The freezing temperature was $-17.7^{\circ} \mathrm{C}$ and the number of freezing cycles was one and five. The stability of the aggregates was analyzed by the wet sieving method of BRYAnT et al. (1948). ChepiL (1954) studied the effects of seasons on the structure of soil, and the method of studying the aggregate stability was both the wet sieving method of YoDER (1936) and his own dry sieving method (CHEPIL 1952).

LOGSDAIL and WEBBER (1959) have also used the wet sieving method of YODER (1936) when studying the behaviour of frozen $\left(-26^{\circ} \mathrm{C}\right)$ soil after freezing at five different soil moisture contents. The number of freezing cycles was $0-3$ in their experiments. The same wet sieving method as such or modified has been used also e.g. by Willis (1955), SillanpäÄ and WebBer (1961), SAINI et al. (1966) and BRYAN (1971). The method of BRYANT et al. (1948) has been used e.g. by Domby and Kohnke (1955) and Soulides and Allison (1961). The method of Bouyoucos (1935) has been used by Bisal and Nielsen 
(1967) and Hinman and Bisal (1968). Meyer and Rennenkampff (1936) have developed a rather gentle wet sieving method and a modification of this has been used e.g. by KaILA (1952).

Both Yoder (1936) and BRYAnt et al. (1948) have aimed at developing their methods to correspond to the effects of erosion caused by rain. In the Finnish climatic conditions this type of erosion apparently has not so great effects as in those parts of the USA, where the methods have been developed. But, because different wet sieving methods are quite widely used in many types of analyses, it has been included in this study, too, in order to make it possible to compare these results with the other ones.

The dry sieving methods seem not to be as commonly used as the wet sieving methods. The idea of this method is to simulate the mechanical strenght of soil against different tillering operations. These methods have been employed e.g. by Chepil (1962), Bisal and Nielsen (1967), Hinman and Bisal (1968) and Toogoop (1978). According to CHePIL (1962), dry sieving is, in fact, the only usable method in cases, where the differences between different factors are small.

Water-dropping as a method of analysis is neither a very common method, apparently due to its laboriousness. The scarcity of information achieved by this method may also be one reason for the minor use of the method. It seeks to clarify how the soil aggregetes withstand the breaking energy of rain drops and what makes the soil become sludged. These factors are important particularly in areas, where the rains tend to be very heavy.

Mc CALla (1944) is one of the first researches to use the water-drop analysis as an analytical method. Later this method or some modification of it has been used by Smith and CERnudA (1951), KAIlA (1952), Low (1954) and more recently by SLONEKER et al. (1976) and GHADIRI and PAYNE (1977). An apparatus for analyzing a larger amount of soil aggregates has been developed e.g. by Sekera and Brunner (1943), Koepf (1956), Njøs (1959) and Rose (1960). BIRECKI et al. (1968) have introduced in their method book an apparatus for analyzing a large series of soil aggregates.

In addition to the methods used reflecting the change in aggregate stability as a result of freezing, Hrnman and Bisal (1973) studied the change in the percolation rate and BENOIT (1973) the change in the hydraulic conductivity. His study was based on an earlier study according to which ice formation decreased the relative mobility of water and thereby increased the water retention in silt loam (BEnort and Bornstern 1970).

1. Pre-treatment of aggregates for stability an a lyses

The interpretation of results by aggregate stability measurements is in general easier when only one aggregate fraction size is under inspection than if there were several sizes. According to KEMPER and CHEPIL (1965) a big enough aggregate size ensures a good representation of the material the aggregates are taken from. On the other hand, it is obvious that when part of the aggregates is left out of the analysis some information will be lost (ScHALLER and STOCKINGER 1953). 
In this experiment only one aggregate fraction size was analyzed because of the easier interpretation of the results. But by choosing a relatively big aggregate size, 5-10 $\mathrm{mm}$, the disadvantage of a small amount of soil analyzed was avoided.

The pretreatments of the aggregates were as follows:

Twenty-five grams of sieved aggregates $5-10 \mathrm{~mm}$ in size were weighed into a 0.31 plastic box. The aggregates were moistened with an atomizer to the water potentials of $-0.06,-0.34$, -3.2 , and -15.0 bar respectively.

The freezing temperatures were $-5^{\circ}$ and $-25^{\circ} \mathrm{C}$. In addition, there was a wetting-drying treatment which instead of freezing included moistening of the aggregates to the corresponding water potential as those frozen. The number of freezing/wetting-drying cycles was five. One cycle included 3.5 days in a freezing chamber/in a $+5^{\circ} \mathrm{C}$ room and another 3.5-day thawing in $\mathrm{a}+5^{\circ} \mathrm{C}$ room/drying at room temperature. The aggregates were during the whole freezing treatment in a tightly closed box. The aggregates of the wetting-drying treatment were kept at room temperature in open boxes, and in the $+5^{\circ} \mathrm{C}$ room the boxes were closed. Before the aggregates in this last treatment were brought back into the $+5^{\circ} \mathrm{C}$ room they were moistened anew to the initial water potential.

After five cycles the aggregates were let to dry at room temperature air dry before the stability analyses were started.

Some of the samples were frozen also 25 cycles in addition to the five-cycle treatments. All treatments included four replicates.

\section{Methods of analysis \\ a. Wet sieving}

Ten grams of air dry aggregates were taken into a 0.31 plastic box and moistened with an atomizer to the water potential of -0.1 bar. The moisture was let to equilibrate in a closed box for one day before the sieving was started. The procedure was a modified Yoder (1936) techique. Also the Meyer and RennenkampfF (1936) method was experimented. In spite of this procedure being more gentle than that of YODER, the actual analyses were, however, made by the latter procedure. This, because in the first place the water pressure in the pipe lines was quite uneven in the laboratory and the number of percolations could change according to the water pressure. Second, it was easier to control the water temperature with the method of YODER than with that of MEYer and RENNENKaMpFF.

The sieving speed was $55 \mathrm{r} / \mathrm{min}$. The stroke lenght was $4 \mathrm{~cm}$ and the time of sieving $3 \mathrm{~min}$. If the time was longer, the differences due to treatments disappeared. The series of sieves was $5-2-1-0.5 \mathrm{~mm}$. In the beginning of the sieving the aggregates were poured on top of the sieves, these being in the uppermost position. In this position the aggregates were just below the water surface. The temperature of water was $+20^{\circ} \mathrm{C}$.

\section{b. Dry sieving}

Ten grams of air dry aggregates were taken for sieving. The apertures of the sieves were the same as in wet sieving. The sieving procedure was similar to that used by ELONEN (1971) in his particle size fraction analysis. The time of sieving was $1 \mathrm{~min}$.

\section{c. Water-drop analysis}

The procedure was a modification of the method of Mc CALLA (1944). The aggregate to be analyzed was placed on a screen of $1 \mathrm{~mm}$ in aperture. The height of drop falling from a burette was $30 \mathrm{~cm}$. The water used was distilled water and the size of drops about $0.05 \mathrm{~g}$. Each treatment included 32 aggregates.

The drops were let to fall down at intervals of $3-7 \mathrm{sec}$. This variation is due to the amount of water needed to brake down the aggregate being expressed in milliliters of water instead of number of individual drops, which procedure made the analysis somewhat less laborious. As 
a consequence, it was not possible to keep the height of water head constant, but the range of variation was $15 \mathrm{~cm}$.

Two variations of dropping procedure were employed. In the first the aggregates were air dry in the beginning of dropping. This procedure has been called in this study d $\mathrm{r}$ y a $\mathrm{g} g \mathrm{re}$ $\mathrm{g}$ a te droppings. In the second the aggregates were moistened with an atomizer to the water potential of -0.1 bar about one day before the dropping was started and kept in closed boxes. This procedure has been called sw et a g g regate dropping".

If the aggregates did not break down after $32 \mathrm{ml}$ of water was dropped, the analysis was stopped.

\section{Results of the stability analyses \\ a. Wet sieving}

The results of the sieving analyses are expressed in percentage proportions of the aggregate size fraction of $<1 \mathrm{~mm}$ from the amount of 5-10 $\mathrm{mm}$ aggregates sieved. Though this expression does not give information about the distribution of different aggregate size fractions, it turned out to be both simple and suitable to indicate the effectiveness of the treatments breaking down the big aggregates analyzed.

In general, it seems that the differences between the effects of the treatments measured by wet sieving have not been very remarkable (Table 6). It seems obvious that the natural weakness of the untreated aggregates strongly has determined the level the disruption takes place in each individual sample. Thus, if the proportion of the $<1 \mathrm{~mm}$ aggregates has been in the O-treatment rather low, as is the case with the heavy clay samples, the proportion of this aggregate size fraction has been even after the strongest treatment rather low.

Table 6. Percentage proportion of aggregate size fraction $<1 \mathrm{~mm}$ achieved by wet sieving the aggregates of $5-10 \mathrm{~mm}$ in size after five cycles of wetting-drying $(\mathrm{w}-\mathrm{d})$ or freezings at $-5^{\circ} \mathrm{C}$ or $-25^{\circ} \mathrm{C}$ at soil water potentials of $-0.06,-0.34$ and -3.2 bar. 0 represents the value of untreated aggregate.

\begin{tabular}{|c|c|c|c|c|c|c|c|c|c|c|}
\hline \multirow{2}{*}{ Sample } & \multirow{2}{*}{0} & \multicolumn{3}{|c|}{-0.06} & \multicolumn{3}{|c|}{-0.34} & \multicolumn{3}{|c|}{-3.2} \\
\hline & & $w-d$ & -5 & -25 & $w-d$ & -5 & -25 & $w-d$ & -5 & -25 \\
\hline C 1 & $18^{\mathrm{bc}}$ & $22^{\mathrm{abe}}$ & $25^{\mathrm{ab}}$ & $32^{\mathrm{a}}$ & $20^{\mathrm{be}}$ & $23^{\mathrm{abc}}$ & $23^{\mathrm{abe}}$ & $17^{b e}$ & $15^{\mathrm{e}}$ & $14^{c}$ \\
\hline C 2 & $13^{d}$ & $23^{a b}$ & $23^{\mathrm{ab}}$ & $28^{a}$ & $18^{\text {bed }}$ & $12^{\mathrm{d}}$ & $18^{\text {bed }}$ & $21^{a b e}$ & $17^{\text {bed }}$ & $14^{\mathrm{ed}}$ \\
\hline C 3 & $10^{d}$ & $18^{\text {bed }}$ & $27^{b}$ & $31^{\mathrm{a}}$ & $22^{\mathrm{bc}}$ & $16^{\text {bed }}$ & $15^{\mathrm{ed}}$ & $15^{\mathrm{ed}}$ & $13^{\mathrm{ed}}$ & $12^{\mathrm{ed}}$ \\
\hline C 4 & $5^{e}$ & $10^{e d}$ & $13^{b}$ & $20^{a}$ & $10^{e d}$ & $10^{\mathrm{be}}$ & $13^{b}$ & $6^{e}$ & $7^{\text {de }}$ & $6^{e}$ \\
\hline S 1 & $64^{b}$ & $80^{a}$ & $75^{\mathrm{ab}}$ & $74^{\mathrm{ab}}$ & $71^{a b}$ & $67^{a b}$ & $66^{b}$ & $65^{b}$ & $66^{b}$ & $66^{b}$ \\
\hline S 2 & $63^{b}$ & $74^{\mathrm{ab}}$ & $85^{a}$ & $86^{a}$ & $67^{b}$ & $70^{\mathrm{b}}$ & $69 \mathrm{be}$ & $50^{d}$ & $48^{d}$ & $52^{d}$ \\
\hline S 3 & $48^{e}$ & $59^{b}$ & $69^{a}$ & $68^{a}$ & $61^{\mathrm{ab}}$ & $49^{e}$ & $48^{e}$ & $53^{\text {be }}$ & $47^{e}$ & $46^{e}$ \\
\hline 34 & $47^{e}$ & $85^{\text {be }}$ & $96^{\mathrm{a}}$ & $90 \mathrm{ab}$ & $77^{e}$ & $68^{d}$ & $81^{\text {be }}$ & $48^{e}$ & $52^{\mathrm{e}}$ & $54^{e}$ \\
\hline
\end{tabular}

Means in each line followed by a common letter do not differ at $\mathrm{P}=0.05$.

A generally accepted view is that freezing of moist soil aggregates is more effective than that of drier soil. In this experiment it seems that in heavy clay samples the freezing at the potential of -0.06 bar has significantly increased 
the proportion of $<1 \mathrm{~mm}$ aggregates achieved by wet sieving. At the potential of -0.34 bar there seems to be a slight tendency the proportion to increase, though the differences between these treatments and the 0 -treatment have not been significant in all cases. Freezing at lower potentials has not had any influence.

In silty clay samples S $1-\mathrm{S} 3$ the moisture content has been only at the potential of -0.06 bar high enough to ensure the aggregating effect of freezing. In the sample S $4-$ high in organic carbon content, $7.8 \%-$ also -0.34 bar has represented a water content high enough for a positive effect of freezing.

Freezing at $\mathbf{- 1 5 . 0}$ bar potential had no disruptive effect on any sample.

The effects of the temperatures seem to be very similar, particularly the effects on the silty clay samples. In heavy clay samples there is some tendency for the disruptive effect of $-25^{\circ} \mathrm{C}$ to be slightly stronger than that of $-5^{\circ} \mathrm{C}$ at the potential of -0.06 bar.

In literature there is a common view about the certain similarity of the effects of freezing and wetting-drying procedures, and the results achieved here agree with the opinion. As is the case with freezing, its aggregating effect is most conspicuous at the -0.06 bar potential in all the samples and in the heavy clay samples it is slight also at the potential of -0.34 bar. It seems thus that the water potential is more decisive for determining the proportion of $<1 \mathrm{~mm}$ aggregate size fraction than the procedure of treating the aggregates, whether it is wetting-drying or freezing.

The procedure of 25 freezing cycles was applied only to the heavy clay aggregates and the water potentials during the freezing were -0.34 and $-\mathbf{1 5 . 0}$ bar. The wetting-drying treatment was not used. Also in this test freezing at the $-\mathbf{1 5 . 0}$ bar potential had no disruptive effect on the $5-10 \mathrm{~mm}$ aggregates. But by increasing the number of freezing cycles from 5 to 25 at the water potential of -0.34 bar, the proportion of $<1 \mathrm{~mm}$ aggregate size fraction has increased remarkably (Table 7 ), particularly when freezing at $-25^{\circ} \mathrm{C}$. The differences between the corresponding figures in Tables 6 and 7 are all at $-25^{\circ} \mathrm{C}$ statistically significant, but those at $-5^{\circ} \mathrm{C}$, on the contrary, are not. It seems, however, that also at this higher temperature there is a tendency for the aggregating effect to be more effective at 25 cycles than at $\mathbf{5}$ cycles. The differences between the effects of temperatures on each sample in Table 7 are all statistically significant.

Table 7. Percentage proportion of aggregate size fraction $<1 \mathrm{~mm}$ achieved by wet sieving the aggregates of 5-10 $\mathrm{mm}$ in size after 25 freezing cycles at -0.34 bar soil water potential and at the temperatures of $-5^{\circ} \mathrm{C}$ and $-25^{\circ} \mathrm{C}$.

\begin{tabular}{ccccc}
\hline Temperature & C 1 & C 2 & C 3 & C 4 \\
\hline-5 & 30 & 19 & 19 & 11 \\
-25 & 36 & 40 & 37 & 22 \\
\hline
\end{tabular}




\section{b. Dry sieving}

The results of dry sieving as a whole are not fully analogous to the results of wet sieving (Table 8). In general, the effects of the freezing treatments have been quite similar when measured by this method as when measured by wet sieving. Particularly the heavy clay aggregates have broken more effectively at the higher water potentials than at the lower potentials. Freezing at -3.2 bar has been also by this measurement ineffective. But, contrary to the results of wet sieving, for the silty clay samples freezing at -0.06 bar potential has not had any effect on the proportion of $<1 \mathrm{~mm}$ aggregate size fraction, but a slight tendency could be seen in the sample S 4 .

Table 8. Percentage proportion of aggregate size fraction $<1 \mathrm{~mm}$ achieved by dry sieving the aggregates of 5-10 mm in size after five cycles of wetting-drying $(\mathrm{w}-\mathrm{d})$ or freezings at $-5^{\circ} \mathrm{C}$ or $-25^{\circ} \mathrm{C}$ at soil water potentials of $-0.06,-0.34$ and -3.2 bar. 0 represents the value of untreated aggregate.

\begin{tabular}{|c|c|c|c|c|c|c|c|c|c|c|}
\hline \multirow{2}{*}{ Sample } & \multirow{2}{*}{0} & \multicolumn{3}{|c|}{-0.06} & \multicolumn{3}{|c|}{-0.34} & \multicolumn{3}{|c|}{-3.2} \\
\hline & & $\mathbf{w}-\mathrm{d}$ & -5 & -25 & $w-d$ & -5 & -25 & $w-d$ & -5 & -25 \\
\hline C 1 & $0^{d}$ & $4^{b c}$ & $6^{b}$ & $8^{a}$ & $4^{e}$ & $4^{\mathrm{be}}$ & $5^{\text {be }}$ & $3^{e}$ & $1^{\mathrm{d}}$ & $1^{\mathrm{d}}$ \\
\hline C 2 & $0^{\mathrm{e}}$ & $3^{\mathrm{a}}$ & $1^{\mathrm{e}}$ & $2^{b}$ & $3^{a}$ & $1^{\text {be }}$ & $1^{\mathrm{a}}$ & $3^{\mathrm{a}}$ & $1^{\mathrm{e}}$ & $1^{\mathrm{e}}$ \\
\hline C 3 & $0^{f}$ & $3^{\mathrm{a}}$ & $1^{\text {de }}$ & $2^{\mathrm{ab}}$ & $2^{\mathrm{ed}}$ & $1^{\mathrm{e}}$ & $1^{\text {de }}$ & $2^{\text {be }}$ & $0^{e}$ & $0^{e}$ \\
\hline C 4 & $1 \mathrm{~g}$ & $6^{b}$ & $4^{\mathrm{be}}$ & $9^{a}$ & $4^{e d}$ & $2^{e}$ & $4^{e}$ & $2^{\text {de }}$ & $2^{e}$ & $1^{t}$ \\
\hline S 1 & $1^{\mathrm{d}}$ & $5^{b}$ & $1^{\mathrm{d}}$ & $1^{\mathrm{ed}}$ & $11^{\mathrm{a}}$ & $1^{\mathrm{ed}}$ & $1 \mathrm{ed}$ & $3^{\text {be }}$ & $1^{\mathrm{ed}}$ & $1^{\mathrm{d}}$ \\
\hline S 2 & $1^{\mathrm{e}}$ & $5^{\mathrm{a}}$ & $1^{\mathrm{e}}$ & $1^{\mathrm{e}}$ & $4^{\mathrm{ab}}$ & $2^{e}$ & $2^{\mathrm{e}}$ & $3^{b}$ & $1^{\mathrm{e}}$ & $1^{e}$ \\
\hline S 3 & $0^{\mathrm{e}}$ & $1^{\mathrm{a}}$ & $0^{\mathrm{e}}$ & $1^{\mathrm{a}}$ & $1^{\mathrm{ab}}$ & $1^{\mathrm{ab}}$ & $1^{\mathrm{ab}}$ & 1 a & $1^{b}$ & $1^{\mathrm{ab}}$ \\
\hline S 4 & $1^{\mathrm{e}}$ & $8^{a}$ & $3^{\text {be }}$ & $3^{\text {bed }}$ & $4^{b}$ & $2^{\text {ede }}$ & $1^{\mathrm{e}}$ & $4^{\mathrm{be}}$ & $2^{\text {ede }}$ & $2^{\text {de }}$ \\
\hline
\end{tabular}

Means in each line followed by a common letter do not differ at $\mathrm{P}=0.05$.

The different effects of freezing temperatures have been apparent at the water potential of -0.06 bar in heavy clay samples. Freezing at $-25^{\circ} \mathrm{C}$ has more effectively broken the aggregates than $-5^{\circ} \mathrm{C}$, the difference being statistically significant for all the samples. In the silty clay samples the effects of the temperatures have been equal.

The most conspicuous difference between the results of the wet sieving and dry sieving analyses seems to be the ability of the methods to measure the effect of wetting-drying treatment. In many cases the wetting-drying treatment has been more effective in disrupting 5-10 $\mathrm{mm}$ aggregates than freezing. Even at the potential of -3.4 bar its effect has been obvious particularly on the heavy clay samples, while freezing had no effect at this potential. Still at the potential of $-\mathbf{1 5 . 0}$ bar the proportion of $<1 \mathrm{~mm}$ fraction was in the sample C $13 \%$ - about the same as at the other potentials.

When increasing the number of freezing cycles from 5 to 25 the disruptive effect of freezing was enhanced significantly at the potential of -0.34 bar, the freezing temperature being $-25^{\circ} \mathrm{C}$ for all the heavy clay samples (Table 9 ). 
The same was observed in wet sieving. Also at $-5^{\circ} \mathrm{C}$ the disruptive effect seems to have been slightly stronger in $\mathbf{2 5}$ freezing cycles than $\mathbf{5}$ freezing cycles, even though the differences are not significant except in the sample C 2 . At the water potential of $\mathbf{- 1 5 . 0}$ bar, the $\mathbf{2 5}$ freezing cycles had no effect on the proportion of $<1 \mathrm{~mm}$ aggregate size fraction achieved by dry sieving.

A comparison between the effects of temperatures at 25 freezing cycles showed that the temperature of $-25^{\circ} \mathrm{C}$ was in all cases significantly more effective in disrupting heavy clay aggre gates than $-5^{\circ} \mathrm{C}$ (Table 9 ). This

Table 9. Percentage proportion of aggregate size fraction $<1 \mathrm{~mm}$ achieved by dry sieving the aggregates of $5-10 \mathrm{~mm}$ in size after 25 freezing cycles at -0.34 bar soil water potential and at the temperatures of $-5^{\circ} \mathrm{C}$ and $-25^{\circ} \mathrm{C}$.

\begin{tabular}{crrrr}
\hline $\begin{array}{c}\text { Temperature } \\
{ }^{\circ} \mathrm{C}\end{array}$ & $\mathrm{C} 1$ & $\mathrm{C} 2$ & $\mathrm{C} 3$ & $\mathrm{C} 4$ \\
\hline-5 & 2 & 3 & 1 & 2 \\
-25 & 12 & 13 & 5 & 10 \\
\hline
\end{tabular}

conclusion could not be drawn if the number of freezing cycles had been five. According to this, if the increase of the number of freezing cycles has a tendency to enhance disruption of aggregates, it presumably will do it at rather low temperatures.

\section{c. Water-drop analysis}

The disruption of aggregates by water-dropping showed different features in each soil type group. Definition of the point of disruption for silty clay aggregates was simple, because their disruption was a collapse after a certain interval of dropping, whereas the definition of the disruption of heavy clay aggregates was somewhat more difficult. According to the criteria of Mc CALlA (1944), an aggregate can be regarded as disrupted when it has passed a $1 \mathrm{~mm}$ screen. This criteria could, however, not be applied in this work, because in most cases the heavy clay aggregates did not disrupt to parts small enough to pass the $1 \mathrm{~mm}$ screen. Instead of the disruption of the aggregates by collapsing, a more characteristic feature was that an aggregate of a certain size was split from the original aggregate, while the other part stayed whole. Thus, it was much more difficult to define, whether the aggregate was disrupted or not. Therefore, it was decided to define the point when the aggregate had split into at least two pieces of equal size as the point of disruption.

Mc CALla (1944) stated that a slightly smaller number of drops was required to destroy the moist soil lumps than air dry lumps. The results achieved here do not agree with this statement, but the aggregates premoistened have persisted remarkably more water than those dropped as air dry (Table 10). The different results probaly are due partly to the different definitions of disruption and partly to the particle size composition, the soil used by Mc CALLA being subsoil and its clay content only $20 \%$. 
Table 10. Amounts of water $(\mathrm{ml})$ needed to disrupt $50 \%$ of aggregates analyzed by dry aggregate dropping (d) and wet aggregate dropping (w) after five-cycle freezing treatment at $-5^{\circ} \mathrm{C}$ at different soil water potentials.

\begin{tabular}{|c|c|c|c|c|c|c|c|c|}
\hline \multirow{2}{*}{$\begin{array}{l}\text { Soil water } \\
\text { potential bar }\end{array}$} & \multicolumn{2}{|c|}{ C 1} & \multicolumn{2}{|c|}{ C 4} & \multicolumn{2}{|c|}{$\mathrm{S} 1$} & \multicolumn{2}{|c|}{ S 3} \\
\hline & d & $\mathbf{w}$ & d & w & d & w & d & w \\
\hline-0.06 & 0.2 & 1.9 & 0.2 & 6.0 & 0.4 & 1.1 & 0.3 & 1.1 \\
\hline-0.34 & 0.2 & 1.8 & 0.3 & $>32.0$ & 0.3 & 1.2 & 0.3 & 1.6 \\
\hline-3.2 & 0.4 & 32.0 & 0.8 & $>32.0$ & 0.4 & 1.9 & 0.5 & 1.4 \\
\hline-15.0 & 0.5 & 13.5 & 2.0 & $>32.0$ & 0.4 & 1.6 & 0.6 & 2.0 \\
\hline air dry & 0.6 & 3.7 & 1.5 & $>32.0$ & 0.4 & 2.0 & 0.3 & 1.5 \\
\hline
\end{tabular}

According to the results achieved here, the aggregates could be divided into three different classes on the basis of their strength against the dropping water, their limits being naturally very conventional:

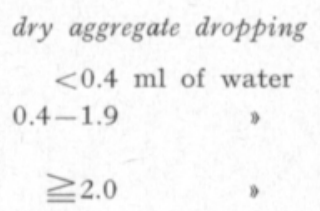

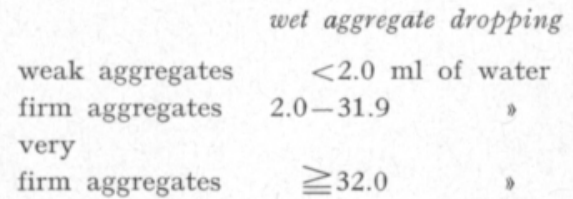

wet aggregate dropping

$<2.0 \mathrm{ml}$ of water

$\geqq 32.0$

This grouping is based on the fact that the firmness of the aggregates in a particular treatment was not normally distributed at all. This was conspicuous particularly at the wet aggregate dropping of heavy clay samples: a part of the aggregates could be very weak and disrupt by a very small amount of water, whereas another part of the same treatment could resist water up to $32 \mathrm{ml}$. This "bipartition" was not so evident in silty clay samples. For example in sample $\mathrm{C} 1$ : at the potential of -0.06 bar after freezing at $-5^{\circ} \mathrm{C}$, $54 \%$ of the aggregates could be classified into the class $<2.0 \mathrm{ml}$ of water at wet aggregate dropping, whereas $30 \%$ of the aggregates belonged to the class $\geqq 32 \mathrm{ml}$ of water. Only $16 \%$ belonged thus to the rather wide class $2.0-31.9 \mathrm{ml}$ of water. In the sample C 4 with the same treatment $41 \%$ of the aggregates belonged to the class $<2.0 \mathrm{ml}$ water and $34 \%$ to that of $\geqq 32 \mathrm{ml}$.

Another criterion for the grouping was that particularly in the heavy clay samples the water limit of $0.4 \mathrm{ml}$ at dry aggregate dropping and $2.0 \mathrm{ml}$ at wet aggregate dropping seems to have reflected rather well the change of firmness of the aggregates. It is thus quite clearly to be seen that the proportion of weak aggregates has diminished both at dry aggregate dropping and at wet aggregate dropping according to the diminishing of the water potential the aggregates were frozen at (Table 11), which tendency was also to be seen in Table 10.

For the silty clay samples the distribution of the aggregates into these firmness classes was not quite so clear as for the heavy clays, but the distribution ranged more widely. Therefore the classification is not quite as suitable for the silty clay soils as for the heavy clay soils. 
Table 11. Percentage proportion of weak C 1- and C 4-aggregates of the total amount in dry aggregate dropping (d) and wet aggregate dropping (w) after different treatments at three soil water potentials. $\mathrm{w}-\mathrm{d}=$ moistened to the water potential and air dried. Five cycles. $-5^{\circ} \mathrm{C}$ and $-25^{\circ} \mathrm{C}=$ freezing temperatures at the corresponding water potential. Five cycles.

\begin{tabular}{|c|c|c|c|c|c|}
\hline \multirow{2}{*}{$\begin{array}{l}\text { Soil water } \\
\text { potential bar }\end{array}$} & \multirow{2}{*}{ Treatment } & \multicolumn{2}{|c|}{ C 1} & \multicolumn{2}{|c|}{ C 4} \\
\hline & & $\mathrm{d}$ & $\mathbf{w}$ & $\mathrm{d}$ & $\mathbf{w}$ \\
\hline \multirow{3}{*}{-0.06} & $w-d$ & 97 & 41 & 52 & 41 \\
\hline & $-5^{\circ} \mathrm{C}$ & 94 & 54 & 84 & 44 \\
\hline & $-25^{\circ} \mathrm{C}$ & 94 & 72 & 85 & 57 \\
\hline \multirow[t]{3}{*}{-0.34} & $w-d$ & 66 & 38 & 22 & 25 \\
\hline & $-5^{\circ} \mathrm{C}$ & 82 & 55 & 59 & 19 \\
\hline & $-25^{\circ} \mathrm{C}$ & 84 & 38 & 78 & 22 \\
\hline \multirow[t]{3}{*}{-3.2} & $w-d$ & 44 & 44 & 3 & 3 \\
\hline & $-5^{\circ} \mathrm{C}$ & 34 & 13 & 6 & 22 \\
\hline & $-25^{\circ} \mathrm{C}$ & 59 & 16 & 19 & 22 \\
\hline Untreated & & 31 & 16 & 0 & 9 \\
\hline
\end{tabular}

In spite of the water limits of $0.4 \mathrm{ml}$ and $2.0 \mathrm{ml}$ being conventional, a rather good accordance is, however, to be observed between the proportions of weak aggregates defined by these limits and the water potential at freezing. For example, after freezing at $-25^{\circ} \mathrm{C}$ the correlation coefficients between the proportion of weak aggregates achieved by droppings and the water potentials by freezing were in all the samples analyzed the following:

$\begin{array}{llllll}\mathrm{C} 1 & \mathrm{C} 4 & \mathrm{~S} 1 & \mathrm{~S} 2 & \mathrm{~S} 3 & \mathrm{~S} 4\end{array}$

$\begin{array}{llllllll}\text { wet aggreg. dropping } & \ldots . . . . & 0.80 & 0.88 & 0.86 & 0.99^{* *} & 0.88 & 0.39 \\ \text { dry aggreg. dropping } & \ldots . . . & 0.99^{* *} & 0.96^{* *} & 0.85 & 0.94^{* *} & 1.00^{* * *} & 0.84\end{array}$

In addition to the figures showing the dependence between the proportion of weak aggregates and the water potential at freezing to be clear, they also allow to suppose that dry dropping apparently is a more sensitive method of stability analysis than wet dropping.

Instead of the great dependence of the water potential at freezing, the results showed that the disruption was almost fully independent of the freezing temperature. And, contrary to the results of dry sieving, the effects of wettingdrying treatments did not differ from those of freezing treatments.

The fact that the amount of water needed to break down the aggregates is smaller in dry dropping than in wet dropping obviously shows that water added with atomizer to the aggregates diminishes the breaking effect of dropping water (cf. Detmmann 1958). This effect appears for example in the soil C 1: all the 475 aggregates analyzed at dry dropping disrupted before $32 \mathrm{ml}$ of water was consumed. At wet dropping 167 out of the 480 aggregates analyzed belonged to the class over $32 \mathrm{ml}$ of water. Of the soil C 4, 478 aggregates were analyzed by dry dropping and in seven of these the firmness exceeded 
the water amount of $32 \mathrm{ml}$, whereas at wet dropping 281 aggregates out of the 480 analyzed belonged to this class. On the other hand, a noteworthy fact is however, that within each treatment at wet dropping some of the aggregates were weak enough to be classified as weak aggregates. This indicates that all the moistened aggregates did not get stronger, but some of them remained weak.

The water-drop analysis would be a suitable quantitative method of analysis, if it was possible to determine in all cases the amount of water needed to break down the aggregates per unit of weight of soil. This method has been used by Mc CALLA (1944). The material may, however, contain aggregates which do not disrupt after a reasonable dropping time, as was true in this study. Therefore it is not always possible to evaluate the quantity. In the present work the upper limit of dropping was $32 \mathrm{ml}$. Aggregates requiring more water than $32 \mathrm{ml}$ to disrupt excisted particularly at wet dropping. For example out of the untreated C 4 aggregates over $90 \%$ belonged to the very firm aggregates. At the potentials of -3.2 and $-\mathbf{1 5 . 0}$ bar the average proportion was abot $70 \%$. Only at the potential of -0.06 bar their proportion was less than $20 \%$.

Also at dry dropping there were some aggregates, capable of withstanding the disruptive effect of water drops up to $32 \mathrm{ml}$ of water. In spite of the fact that it has not been possible to calculate the exact amounts of water per gram of soil at these treatments, the values given in Table 12 clearly show the significance of the water potential on the disruptive effect of freezing. It seems apparent that particularly freezing at the potentials of -0.06 and -0.34 bar has been effective in disrupting soil aggregates. Freezing at the potential of -3.2 bar or lower has had no effect on the result. The results thus show that by diminishing the water potential from -0.34 bar to -3.2 bar the effect of freezing, too, ceases very sharply. This is true particularly with the heavy clay soils analyzed, but not so evident with the silty clay soils.

Table 12. Amounts of water $(\mathrm{ml})$ needed at dry aggregate dropping to brake down $1 \mathrm{~g}$ of aggregates after five-cycle freezing treatment at $-25^{\circ} \mathrm{C}$ at different soil water potentials.

\begin{tabular}{|c|c|c|c|c|c|c|}
\hline & Sample & -0.06 & -0.34 & -3.2 & -15.0 & air dry \\
\hline C 1 & n................ & 1.28 & 1.44 & 3.16 & 5.37 & 5.46 \\
\hline C 4 & n............... & 1.64 & 1.60 & $7.56(+2)$ & 11.94 & $23.92(+1)$ \\
\hline S 1 & n................ & 1.77 & 2.31 & 2.77 & 2.85 & 2.26 \\
\hline S 2 & n............... & 2.52 & 2.54 & 3.75 & 3.34 & 7.42 \\
\hline S 3 & n................ & 1.97 & 2.26 & 2.70 & 3.20 & 3.01 \\
\hline S 4 & ................. & 2.80 & 2.80 & 6.21 & 3.97 & 4.36 \\
\hline
\end{tabular}

$(+2)$ and $(+1)$ indicate that two $(+2)$ or one $(+1)$ aggregates of the total 32 aggregates have been so firm that $32 \mathrm{ml}$ of water has not been sufficient to break them down.

As was done in the sieving analyses, here too the effect of the number of freezing cycles on the disruption of heavy clay aggregates was examined. Contrary to the results of sieving, it could be established that the number of freezing cycles had no effect on the aggregate stability. In agreement with 
former observations, freezing at the potential of $\mathbf{- 1 5 . 0}$ bar had no effect on the stability of the aggregates, which result is very obvious according to the results in Table 12 .

\section{The freezing mechanism as a factor changing the aggregate porosity}

The results of the former chapters have shown that the structural changes of soil due to freezing may be very remarkable, which, in fact, is already known by experience and from numerous studies on the effects of soil frost. These studies are e.g. TABER (1930), Jung (1931 a, 1931 b), BEskow (1935), ERIKsson (1941), SillanpäÄ (1961), Bisal and Ferguson (1968), Bryan (1971), CzeRATZKI (1971), Benoit (1973), Richardson (1976), and others. In spite of the relatively large number of studies, the mechanism of frost as a factor changing the soil structure seems to have been discussed more seldom. The aim of this chapter and the following is to unravel the factors which cause the change in the structure of soil aggregates by freezing.

The structural property under discussion will be the total pore volume and its changes. A basis for this inspection is the fact that the soil volume, particularly that of the clay soils, will increase if the water content increases. This soil property has already been studied by TEMPANy (1917) and HaInes (1923). A natural consequence of total volume increase is the increase of total pore volume. And, as far as the soil freezing is concerned, the volume changes taking place in soil are apparently also attributed to the changes of water volume at freezing, to some extent at least. Thus, it was decided to examine the following treatments affecting the aggregate pore volume:

- The total pore volumes of aggregates and their changes due to water potentials.

- The changes of total pore volumes as a consequence of freezing and thawing.

- The changes of total pore volumes as a consequence of moistening and air drying.

- The changes of total pore volumes as a consequence of freezing and freeze-drying.

The aggregate size fraction analyzed was 5-10 $\mathrm{mm}$ achieved by dry sieving from original material.

1. Pre-treatments of aggregates for total porevolume determinations

All the agregates were first moistened with an atomizer to the water potentials of -0.02 , $-0.1,-1.0$, and -15.0 bar respectively. Each treatment consisted of four parallels. The water content was controlled by weighing.

\section{a. Preparation of aggregates for determination of total pore volume as moist}

After wetting the aggregates were covered immediately with a plastic cover to prevent evaporation. The moisture was let to equilibrate for two hours at room temperature before the pore volume determination.

b. Preparation of aggregates for determination of total pore volume of frozen, thawed and air dried aggregates

The moist aggregates were brought in tightly closed boxes into a $+5^{\circ} \mathrm{C}$ room for the night. The following day they were taken into the temperatures of $-5^{\circ}$ and $-35^{\circ} \mathrm{C}$ respectively. 
The freezing period lasted four days, whereafter the specimens were brought into $\mathrm{a}+5^{\circ} \mathrm{C}$ room for thawing. The thawing period lasted one day, whereupon the boxes were opened and the aggregates were let to dry at room temperature befor determination of total pore volume.

\section{c. Preparation of aggregates for determination of total pore volume of moistened and air dried aggregates}

The moist aggregates were kept at room temperature for two hours covered with plastic. After the plastic was removed, the aggregates were let to dry air dry at room temperature before determination of total pore volume.

\section{d. Preparation of aggregates for determination of frozen and freeze-dried aggregates}

The moistened aggregates were brought in closed boxes into $-5^{\circ} \mathrm{C}$ and $-35^{\circ} \mathrm{C}$ chambers, like in chapter a. After freezing they were taken into a $-20^{\circ} \mathrm{C}$ room and the boxes were opened. The aggregates were let to dry in this room for one month and thereafter brought into room temperature. After one day's temperature equilibrium the total pore volume was determined.

\section{Determination of total pore volume of a g g r e g a t es}

Generally there are not too many methods for determining the total pore volume of soil. In this particular case, the fact that the specimen under inspection must not lose its structural properties during determination furthermore limits the choices. The water retention analysis is widely used for determination of pore size distribution, especially for undisturbed samples. By this method the specimen will lose its original structure already at wetting. BLAKE (1965 a) has proposed a method, where the aggregate is covered with paraffin in order to prevent the water from penetrating into the soil. The main disadvantage of this method is that the aggregates cannot be reused after the determination. Further, when this method was tried, it could be observed that the method is extremely sensible to changes in the paraffin temperature. Even minor deviations would affect the result.

SUNKEL (1960) has introduced a mercury method which, after some improvements, proved suitable. The principle of the method is that in a container of a certain size the aggregate under analysis displaces a certain volume of mercury, and this volume can be defined gravimetrically.

\section{a. Determination of total pore volume of aggregates by the modified method of SUNKEL}

The measuring procedure was similar to that of SunKeL (1960) (Fig. 7). The measure (A) was made from a sintered glass filter (G) (pore size G 4) $15.5-16.7 \mathrm{ml}$ in volume. The height of the mercury head was $10 \mathrm{~cm}$ and the number of the aggregates analyzed was two or three, depending on the aggregate size.

The component of the apparatus to be weighed during determinations is (I), and for weighing it was detached from the stative at the fastening point (C). The plastic tube (D), not existing in the apparatus of SUNKEL, serves for the mercury to pass more freely when emptying the container (A). The plastic tube thus eliminated also the spilling of mercury when the juncture (E) is being detached.

The determination of the total pore volume of moist aggregates was very similar to that of dry aggregates, but there was a thin plastic on top of the aggregates (F) in the container (A) 


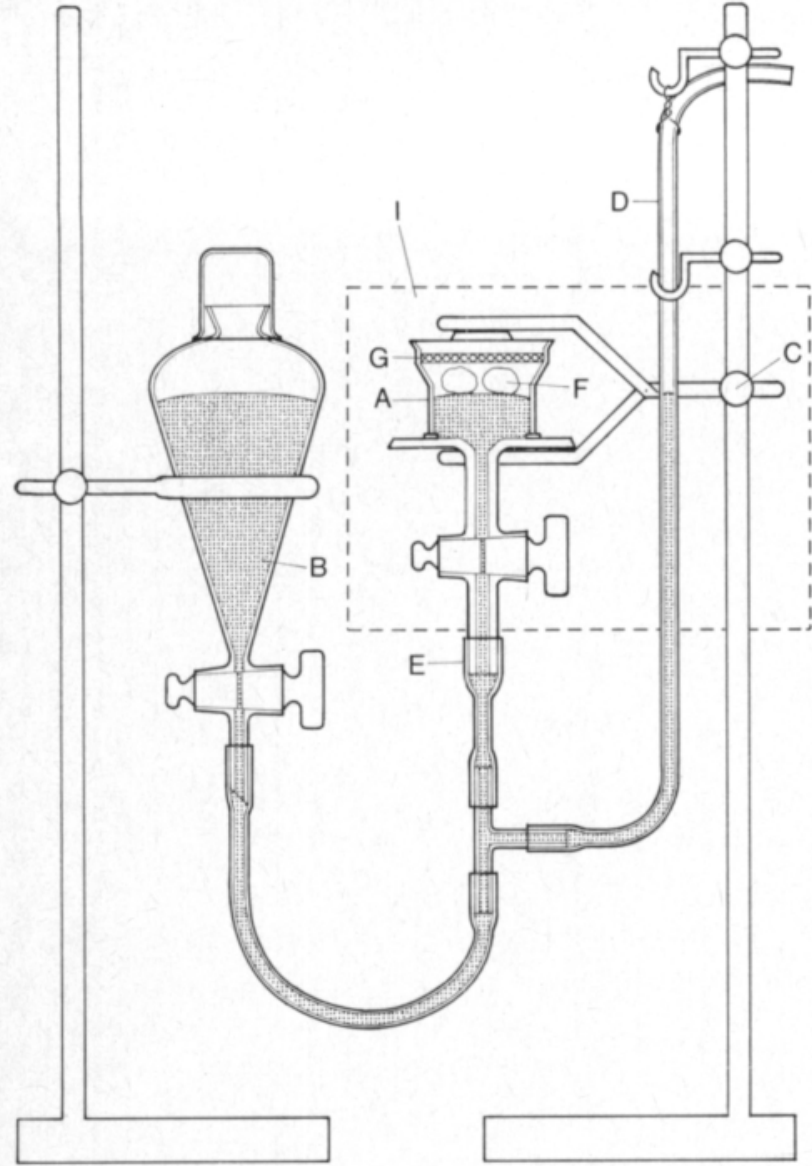

Fig. 7. Apparatus employed for determination of total pore volume. Symbols: see the text.

during the measurement. Without plastic the glass filtẹr $(\mathrm{G})$ suck up the moisture from the aggregates (F) and the weight of the component (I) also changed.

A disadvantage, especially when analysing silty clay aggregates, was the accumulation of fine dust on the surface of the mercury. Therefore, the mercury was filtered after every 16 determinations. In fact, this dust had, however, no influence on the results, which could be stated by measuring the same specimen before and after filtering. The amounts of dust were in most cases too small to be weighed by the scales used in these analyses (accuracy $1 \mathrm{mg}$ ).

The fact that leaves room for interpretation is what size of holes on the aggregate surface are to be regarded as pores. By using a great pressure of mercury at the determination, the mercury penetrates to smaller pores than when the pressure is lower. This problem can be eliminated to some extent by using in each treatment the same mercury pressure. This procedure does not, however, eliminate the fact, that aggregates differ from each other as a result of different treatments and, as a consequence, penetration of mercury also differs.

Another problem in the analysis was the sticking of mercury on the aggregates during the treatments. This was true particularly with very porous aggregates. The mercury thus increased their weight. This source of error was eliminated in later calculations by using the original weight as a basis for calculations, though some of the original weight may have been lost as dust. But as expressed above, its proportion was insignificant. As a result of this calculation method the holes on the outer surface of aggregates filled with mercury have thus been regarded as holes of aggregates, not pores. 


\section{b. Testing the method of determination of total pore volume}

\section{The method was tested by the following way:}

Samples C 2, C 3, S 2, and S 3 were suspended with $600 \mathrm{ml}$ of water in the proportion of $1: 1$. The suspensions were let to stand for some days to ensure thorough wetting before being poured on sintered glass filters (pore size G 4). The water head was fixed to $100 \mathrm{~cm}$. The time for equilibrium was one week.

Small soil cylinders were made from the wet soil paste in equilibrium by taking it with a spatula into a small plastic cylinder, $5 \mathrm{ml}$ in volume. The height of the cylinder was $10.2 \mathrm{~mm}$ and diameter $17.0 \mathrm{~mm}$. Each treatment consisted of three parallels and the treatments were as follows:

treatment A: The soil cylinders were let to dry at room temperature as such.

- B: The soil cylinders were taken into a $-15^{\circ} \mathrm{C}$ chamber for a four-day freezing. To prevent evaporation they were covered with a piece of plastic. After the freezing period the cylinders were brought to $\mathrm{a}+5^{\circ} \mathrm{C}$ room to thaw for three days and thereafter let to dry at room temperature until they were air dry.

- C: Freezing in a $-15^{\circ} \mathrm{C}$ freezing chamber for four days. After the freezing period the cylinders were taken into a $-20^{\circ} \mathrm{C}$ room and the plastic was taken off for freeze-drying. The drying period lasted one month.

Treatment A represents a case, where the soil structure is very compact. The cylinders after treatment $\mathrm{C}$ represent soils with a rather porous structure. It was to be feared with the porous cylinders that the penetration of mercury into the pores of the specimens would cause great variations between the parallels within different treatments. The results show, however, that this was not the case (Table 13). The differences between the standard deviations in each soil sample are not statistically significant.

Table 13. Total pore volumes (\%) of homogenous samples moistened to soil water potential of -0.1 bar after drying at room temperature $(\mathrm{A})$, frozen at $-15^{\circ} \mathrm{C}$, thawed and dried at room temperature (B), and freeze-dried at $-20^{\circ} \mathrm{C}$ after $-15^{\circ} \mathrm{C}$ freezing (C).

\begin{tabular}{ccccc}
\hline Treatment & C 2 & C 3 & S 2 & S 3 \\
\hline \multirow{2}{*}{ A } & 22.4 & 26.7 & 32.2 & 37.9 \\
& 22.0 & 26.7 & 32.2 & 36.8 \\
\hline Mean & 22.4 & 26.3 & 32.2 & 35.2 \\
s & 22.3 & 26.6 & 32.2 & 36.6 \\
& 0.202 & 0.225 & 0.00 & 1.374 \\
B & 24.9 & 27.1 & 32.6 & 34.2 \\
& 24.2 & 26.3 & 31.7 & 34.7 \\
\hline Mean & 25.3 & 27.5 & 30.8 & 32.7 \\
s & 24.8 & 27.0 & 31.7 & 33.9 \\
& 0.579 & 0.600 & 0.940 & 1.030 \\
C & 30.8 & 34.1 & 35.7 & 42.6 \\
& 30.8 & 33.6 & 36.2 & 42.0 \\
Mean & 32.2 & 33.6 & 36.7 & 42.0 \\
s & 31.2 & 33.8 & 36.2 & 42.2 \\
\hline
\end{tabular}

The test was further continued by the moistening soil cylinders anew to a water potential of -0.001 bar. The procedure was the ordinary capillary procedure on a foamy plastic. The 
purpose of this continued treatment was to establish whether the mercury in the soil pores causes any deviations in the results when the specimens are further handled. It was supposed that if the mercury in the pores would cause deviations, they would be observed as increased deviations because of the great density of mercury.

After one week of moistening the soil cylinders were let to dry at room temperature air dry and the total pore volume was determined.

The standard deviations acquired from the last measurements (Table 14) do not differ from those of the first measurements. This result thus shows that the deviations have not increased, and the penetration of mercury in the soil pores, which phenomenon was most apparent in treatment $(\mathrm{C})$, is not a factor to misrepresent the results.

Table 14. Total pore volumes (\%) of homogenous samples after moistening and air drying following the treatments (A), (B) and (C). (see text).

\begin{tabular}{ccccc}
\hline Treatment & C 2 & C 3 & S 2 & S 3 \\
\hline \multirow{3}{*}{ A } & 20.7 & 25.6 & 33.6 & 36.8 \\
& 21.7 & 25.6 & 33.6 & 36.3 \\
\hline Mean & 22.0 & 25.9 & 34.1 & 36.3 \\
s & 21.5 & 25.7 & 33.8 & 36.4 \\
& 0.702 & 0.219 & 0.289 & 0.306 \\
B & 23.8 & 26.7 & 34.1 & 33.7 \\
& 23.8 & 25.9 & 32.6 & 34.7 \\
Mean & 24.2 & 27.1 & 32.2 & 33.2 \\
s & 23.9 & 26.6 & 33.0 & 33.9 \\
& 0.214 & 0.590 & 1.018 & 0.764 \\
& 26.1 & 32.2 & 34.6 & 38.5 \\
C & 27.3 & 32.2 & 34.6 & 39.6 \\
& 27.3 & 32.2 & 34.6 & 38.5 \\
\hline Mean & 26.9 & 32.2 & 34.6 & 38.8 \\
s & 0.699 & 0.000 & 0.000 & 0.664 \\
\hline
\end{tabular}

3. Total pore volumes of aggregates and their c h a nges

The moist soil aggregates retain water also on the outer surface. Due to the total pore volume determination procedure employed in this study, the volume of this water will be included in the total pore volume of the aggregate. It is obvious that by increasing the amount of water in the aggregate, also the water content on the aggregate surface will increase. As a consequence, when determinating the total pore volume, it will be greater than the pore volume of the aggregate actually is. Now it is questionable, whether the water on the outer surface is part of the total pore volume of the aggregate or is it part of an outside volume. In this study, it has been decided to include this volume in the aggregate volume and thus it is part of the total pore volume of the aggregate in question. This, because the water on the outer surface is energetically influenced by soil matrix: when increasing the soil water potential the thickness of the water layer also increases and vica versa. 
In the following four chapters the effects of different treatments on the total pore volume of aggregates have been discussed. To make it short, only in the first chapter, dealing with the total pore volumes of moist aggregates, the results have been expressed as total pore volumes. In the later three chapters, dealing with the effects of the different treatments described above (pp. 278-279), results have been expressed only as changes taken place in the aggregates as a the result of the treatment. The object of comparison is the total pore volume of the same aggregate as air dry. The average total pore volumes $\left(\mathrm{V}_{\mathrm{p}_{\mathrm{o}}}\right)$ of aggregates are mean values from 16 determinations of each sample, each determination consisting of two aggregates. These mean values are:

\begin{tabular}{|c|c|c|}
\hline Heavy & clay samples & Silty clay samples \\
\hline C 1 & $37.4 \pm 0.8$ & $\begin{array}{ll}\text { S } 1 & 44.2 \pm 1.3\end{array}$ \\
\hline C 2 & $39.3 \pm 1.3$ & S $247.8 \pm 1.2$ \\
\hline C 3 & $42.0 \pm 0.8$ & S $348.0 \pm 0.7$ \\
\hline C 4 & $42.1 \pm 1.2$ & S $4 \quad 51.5 \pm 1.8$ \\
\hline
\end{tabular}

The changes of total pore volumes $\left(\Delta \mathrm{V}_{\mathrm{p}}\right)$ express the differences between the total pore volumes after treatment and air dry. The figures given in the corresponding tables are expressed in percentage units and are the mean values of four parallels.

\section{a. Total pore volumes of moist aggregates}

The changes in soil volume due to the moisture content are traditionally regarded as linear functions of water contents at certain soil water potentials (Tempany 1917, Haines 1923, Stirk 1954, Sunkel 1964). As far as soil shrinking is concerned, HAINEs has called this soil volume change normal shrinkage. Residual shrinkage he calls the area where the relation between the change of water content and soil volume is no more linear. In very wet soil the changes are not linear either. This shrinking STIRK (1954) has proposed to be called structural shrinkage.

Soil swelling due to moistening is in principle a reverse phenomenon to shrinking. It is thus possible to find the corresponding parts from the swelling curves and the shrinking curves. WARKEntin and BozozuK (1961) have observed that the part of the swelling curve, where the curve begins to change from unlinear to linear is in the position of about $-\mathbf{1 5 . 0}$ bar. STIRK (1954) has observed that in shrinking at the potential of -31.6 bar the curve changes from linear to unlinear.

In the heavy clay samples the increase of the total pore volume seems to have been in this study almost linear from air dry up to the water potential of -0.1 bar (Fig. 8a). Sample C 1, where the organic carbon content has been the smallest $(2.5 \%)$, has shown perhaps the strongest deviation from linearity. The corresponding curves of silty clay soils have deflected more from linearity (Fig. 8b). The increase of the water content from air dry to the water potential of $\mathbf{- 1 5 . 0}$ bar has not increased the total pore volume in any sample. As a matter of fact, it seems to have diminished in sample S 1 and also in S 2, the organic carbon content being lowest in these samples $(3.3 \%$ and $3.7 \%$ respectively). The diminishing is, however, not statistically significant. 

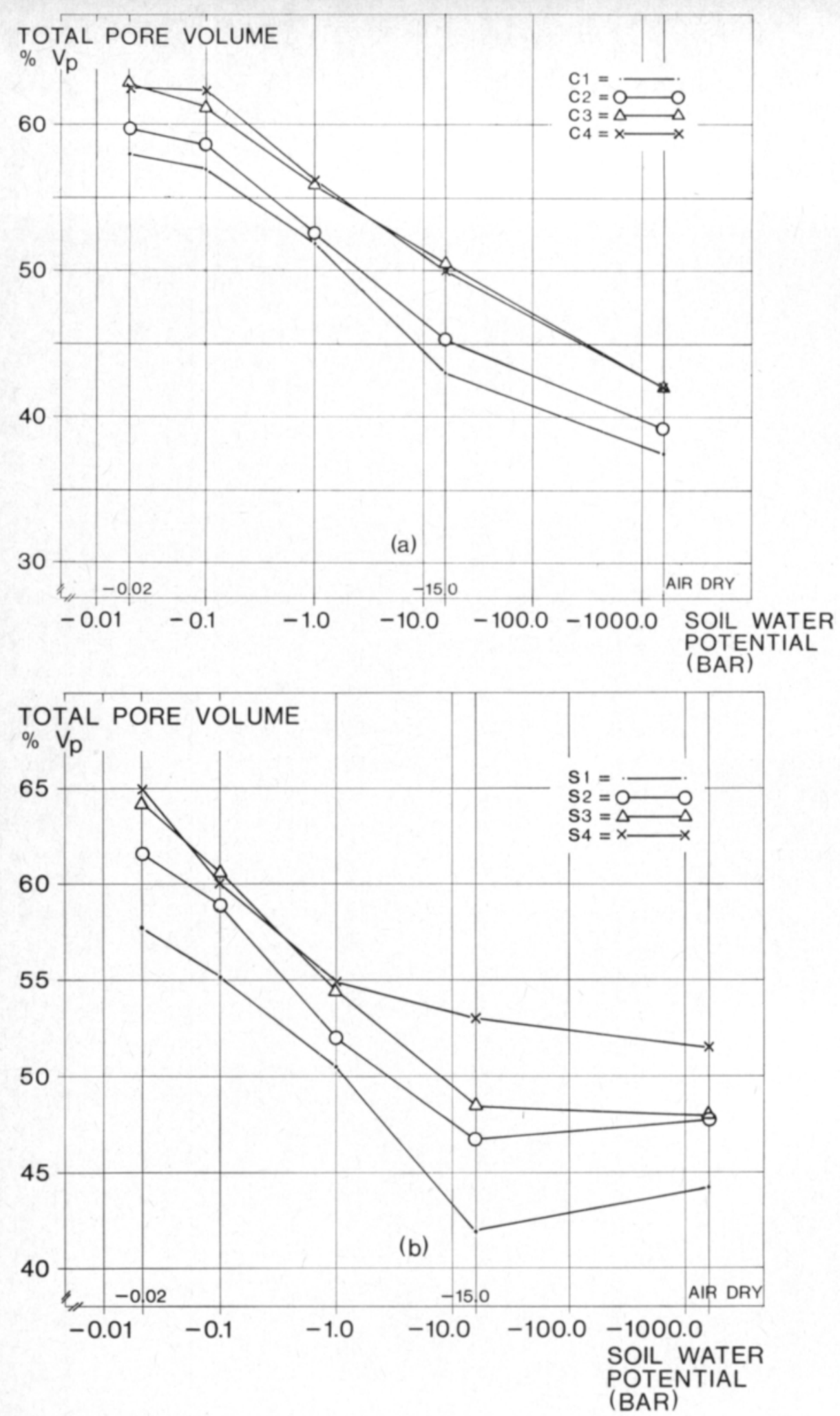

Fig. 8. Relationship between the total pore volume of a) heavy clay and b) silty clay aggregates and the soil water potential (bar). 
The fact that in heavy clay samples the increase of total pore volume by increasing the water potential has been almost linear up to the water potential of -0.1 bar but not in the silty clays, obviously shows that the filling-up mechanism of small pores is not similar and that the nature of small pores is not quite identical. The proportion of small pores is naturally great in heavy clay soils. If no increase of total pore volume would occur as a result of the increase of water content, there would be room for a volume of water equal to the total pore volume only. The extra water would flow away. Because of swelling, the clay soils have, however, more room for water than the air dry pores would imply. When the proportion of the water added to the soil $(\mathrm{ml})$ to the volume of pores $(\mathrm{ml})$ in air dry soil was calculated in this work, it could be observed that in heavy clay aggregates the small pores were filled with water already at the potential of $-\mathbf{1 5 . 0} \mathrm{bar}$, if no swelling had taken place:
Added water $\mathrm{ml}$
C 1
C 2
C 3
C 4
$\overline{\text { Total pore volume } \mathrm{ml}}$
$0.93 \pm 0.14 \quad 1.01 \pm 0.23$
$1.03 \pm 0.06$
$1.03 \pm 0.27$

Though the volume of water added has thus presupposed only the filling-up of the pores, the total pore volume has, however, in all heavy clay samples clearly increased. In practice this means that in heavy clay soils with swelling properties all the pores will be filled with water only at the water potentials where the increase of the soil volume has ceased.

This could be concluded indirectly also from the figures given in Table 15 which express how many percents of the added water was needed for the increase of the pore volume. So, at the potential of -15.0 bar about $25-39 \%$ of the added water has affected the increase of the total pore volume of heavy clay aggregates. In silty clay samples the role of added water at the same water potential has been practically to fill the pores only.

According to Figure 8a and Table 15, it seems that the increase of total pore volume has ceased in heavy clay samples at the water potential of $-0.1 \mathrm{bar}$. The proportion of the increase of the total pore volume to the amount of added water has been at this turning point about $70 \%$ in average. This result indi-

Table 15. Proportion of increase of total pore volume of added water volume in percentages at four soil water potentials (bar).

\begin{tabular}{ccccc}
\hline Sample & -0.02 & -0.1 & -1.0 & -15.0 \\
\hline & & & & $59^{\mathrm{b}}$ \\
C 1 & $68^{\mathrm{a}}$ & $74^{\mathrm{a}}$ & $54^{\mathrm{a}}$ & $25^{\mathrm{e}}$ \\
C 2 & $63^{\mathrm{a}}$ & $74^{\mathrm{a}}$ & $50^{\mathrm{b}}$ & $31^{\mathrm{b}}$ \\
C 3 & $71^{\mathrm{a}}$ & $73^{\mathrm{a}}$ & $54^{\mathrm{b}}$ & $39^{\mathrm{c}}$ \\
C 4 & $70^{\mathrm{a}}$ & & & \\
& & $40^{\mathrm{a}}$ & $27^{\mathrm{b}}$ & $-2^{\mathrm{e}}$ \\
S 1 & $49^{\mathrm{a}}$ & $40^{\mathrm{b}}$ & $22^{\mathrm{c}}$ & $-7^{\mathrm{d}}$ \\
S 2 & $49^{\mathrm{a}}$ & $48^{\mathrm{b}}$ & $24^{\mathrm{c}}$ & $5^{\mathrm{d}}$ \\
S 3 & $63^{\mathrm{a}}$ & $40^{\mathrm{a}}$ & $22^{\mathrm{b}}$ & $8^{\mathrm{e}}$ \\
S 4 & $47^{\mathrm{a}}$ & & & \\
\hline
\end{tabular}

Means in each line followed by a common letter do not differ at $\mathrm{P}=0.05$. 
cates that in heavy clay samples the water added to the soil, corresponding a water potential smaller than -0.1 bar, has in no cases been used entirely either to fill the pores or to increase the pore volume. The filling-up of soil pores has thus been most intensive in conditions, where the soil has been drier than $\mathbf{- 1 5 . 0}$ bar. When, for example, the figures in Table 16 are compared with the corresponding curves in Figure 6 it can be observed that in sample C 1, e.g., the increase of water content from air dry to the potential of -15.0 bar, 18 percentage units, has caused the pore volume to increase about $\mathbf{5}$ percentage units. When the amount of added water has increased 11 percentage units (to $-\mathbf{1 . 0}$ bar), the increase of pore volume has been more intensive, relatively, about 9 percentage units.

The proportion of added water from the air dry total pore volume has been for silty clay aggregates remarkably smaller than for heavy clay aggregates at the potential of $-\mathbf{1 5 . 0}$ bar. The corresponding proportion of about $1: 1$, achieved for heavy clay samples at the potential of -15.0 bar, was achieved for silty clay samples at the potential of -1.0 bar:

$\begin{array}{ccccc}\text { bar } & \text { S } 1 & \text { S } & \text { S } 3 & \text { S } ~ \\ -15.0 & 0.34 \pm 0.02 & 0.24 \pm 0.04 & 0.35 \pm 0.05 & 0.23 \pm 0.02 \\ -1.0 & 1.01 \pm 0.16 & 0.95 \pm 0.17 & 0.95 \pm 0.03 & 0.90 \pm 0.37\end{array}$

But, as expressed in Table 16, the water content corresponding the potential of $-\mathbf{1 . 0}$ bar has caused in silty clay aggregates an increase of total pore volume of the same size as the $\mathbf{- 1 5 . 0}$ bar water content in heavy clay samples. In practice this result shows the difference in swelling in these two soil groups, and obviously the significance of clay fraction. This result is more apparent when the percentage of water contents of the soil samples are taken into consideration (the water content of heavy clay samples at the potential of $\mathbf{- 1 5 . 0}$ bar and that of silty clay samples at the potential of $-1.0 \mathrm{bar}$ ). In fact, the smaller percentage of water content of heavy clay samples as compared to that of silty clay samples has actually caused a greater increase of the total pore volume. However, the fact that the pore volumes of air dry aggregates have also deviated from each other (p. 283) has to be taken into consideration, which as such, too, indicates the significance of clay fraction in determining the soil structure.

At the potential of -0.1 bar in heavy clay aggregates, at which potential the increase of total pore volume ceased, the water content was about $40-50 \%$ (Fig. 6). Although these four samples were rather heterogeneous, as far as the organic carbon content is concerned (Table 6), no very great differences existed between their behaviour at this potential, but the increase of the total pore volume seems to have ceased in all of them. On the other hand, not even the water potential of -0.02 bar seems to have represented the upper limit of pore volume increase for the silty clay samples. This can be understood on the basis of the results of water-drop analysis. The aggregates were observed to lose their original structure by collapsing rather than by clefting and, in fact, the situation is the same here: it was often difficult to determine the total pore volume of the aggregates S 1 and S 2 at this water potential because of the very loose structure. 
Table 16. Changes of total pore volumes $\left(\Delta \mathrm{V}_{\mathrm{p}}\right)$ in percentage units after moistening the air dry aggregates to four soil water potentials (bar).

\begin{tabular}{ccccc}
\hline Sample & -0.02 & -0.1 & -1.0 & -15.0 \\
\hline C 1 & $20.4^{\mathrm{a}}$ & $20.0^{\mathrm{a}}$ & $15.6^{\mathrm{b}}$ & $5.1^{\mathrm{c}}$ \\
C 2 & $20.1^{\mathrm{a}}$ & $17.3^{\mathrm{ab}}$ & $15.1^{\mathrm{b}}$ & $6.6^{\mathrm{c}}$ \\
C 3 & $22.0^{\mathrm{a}}$ & $19.7^{\mathrm{b}}$ & $12.8^{\mathrm{e}}$ & $7.8^{\mathrm{d}}$ \\
C 4 & $20.9^{\mathrm{a}}$ & $19.4^{\mathrm{a}}$ & $14.4^{\mathrm{b}}$ & $8.3^{\mathrm{c}}$ \\
& & & & $-0.2^{\mathrm{c}}$ \\
S 1 & $12.8^{\mathrm{a}}$ & $9.8^{\mathrm{a}}$ & $6.0^{\mathrm{b}}$ & $-0.4^{\mathrm{d}}$ \\
S 2 & $13.3^{\mathrm{a}}$ & $10.0^{\mathrm{b}}$ & $3.8^{\mathrm{e}}$ & $0.4^{\mathrm{d}}$ \\
S 3 & $17.1^{\mathrm{a}}$ & $13.0^{\mathrm{b}}$ & $5.2^{\mathrm{e}}$ & $0.5^{\mathrm{c}}$ \\
\hline S 4 & $11.7^{\mathrm{a}}$ & $10.2^{\mathrm{a}}$ & $4.8^{\mathrm{b}}$ & \\
\hline
\end{tabular}

Means in each line followed by a common letter do not differ at $\mathrm{P}=0.05$.

The effect of clay fraction on the soil properties appears also within the sample S 3. Its clay fraction content was about 10 percentage units higher than that of other silty clay samples (Table 3) and, as can be seen in Tables 15 and 16, its behaviour resembles probably more that of the heavy clay samples than that of other silty clay samples at the potential of -0.2 bar and even at the potential of -0.1 bar it differs from other S-samples. This is worth noticing, particularly since the differences in organic carbon content in both soil groups seem to have had no influence on the pore volume increases, though the pore volumes of the aggregates seem to have been dependent on the organic carbon content.

b. Changes of total pore volumes of aggregates after freezing, thawing and air drying

The process taking place in the field most often resembles the procedure employed in this analysis; the frozen soil first thaws before drying. In general, the system in the field is, however, not closed, but the escape of water is possible during all the phases of the process. It is thus apparent that the openness of the system to a certain degree affects the soil structure. This is concluded from the results achieved in this test. The wetting-freezing-thawing-air-drying procedure had practically no effect on the total pore volume, neither in the heavy clay aggregates nor the silty clay aggregates. In both soil type groups the average pore volumes were after the treatments equal to the corresponding pore volumes before treatments when air dry - quite independent of the water potential or freezing temperature.

The average pore volume values do not exactly expose the changes that may have taken place in the individual aggregates analyzed. Therefore it is reasonable to inspect these changes. It is obvious that in the heavy clay aggregates there may have occurred some increase of the pore volume during the treatments (Table 17). This increase has been rather small, however, about 3 to 4 percentage units at its best. The results in Table 17 express only those achieved by the $-5^{\circ} \mathrm{C}$ treatment, because the results from $-35^{\circ} \mathrm{C}$ 
Table 17. Changes of total pore volumes $\left(\Delta \mathrm{V}_{\mathrm{p}}\right)$ in percentage units after the freezing, thawing and air drying procedure at four soil water potentials (bar). Freezing temperature $-5^{\circ} \mathrm{C}$.

\begin{tabular}{|c|c|c|c|c|}
\hline Sample & -0.02 & -0.1 & -1.0 & -15.0 \\
\hline C 1 & $3.4^{\mathrm{a}}$ & $2.7^{\mathrm{ab}}$ & $3.1^{\mathrm{a}}$ & $0.8^{b}$ \\
\hline C 2 & $3.4^{\mathrm{a}}$ & $2.6^{\mathrm{ab}}$ & $1.3^{\mathrm{be}}$ & $0.4^{e}$ \\
\hline C 3 & $3.3^{\mathrm{a}}$ & $2.7 \mathrm{ab}$ & $1.9^{\mathrm{b}}$ & $1.6^{\mathrm{b}}$ \\
\hline C 4 & $2.8^{\mathrm{a}}$ & $1.4^{\mathrm{ab}}$ & $1.2^{\mathrm{b}}$ & $0.5^{b}$ \\
\hline S 1 & $1.0^{\mathrm{a}}$ & $1.2^{\mathrm{a}}$ & $0.8^{\mathrm{a}}$ & $-0.8^{b}$ \\
\hline S 2 & $0.9^{\mathrm{a}}$ & $1.0^{\mathrm{a}}$ & $0.5^{\mathrm{a}}$ & $-0.8^{\mathrm{b}}$ \\
\hline S 3 & $1.1^{\mathrm{a}}$ & $0.4^{\mathrm{ab}}$ & $0.1^{\mathrm{ab}}$ & $-0.7^{b}$ \\
\hline S 4 & $2.8^{\mathrm{a}}$ & $1.9^{\mathrm{a}}$ & $1.7^{\mathrm{ab}}$ & $-1.4^{b}$ \\
\hline
\end{tabular}

Means in each line followed by a common letter do not differ at $\mathrm{P}=0.05$.

did not differ at any point from these. The silty clay aggregates show hardly any increase in the pore volume, rather the treatments have caused a decrease at the potential of $\mathbf{- 1 5 . 0}$ bar. In fact, this result was anticipated already in the previous test in which the total pore volumes of S 1 and S 2 aggregates seemed to have diminished because of mere moistening. In this test the diminishing seems to have occurred also in the other two silty clay aggregates.

When comparing the results achieved here with those achieved from the wetting treatment alone in the preceding chapter, it seems obvious that the great increase of total pore volume due to the increased water content has no longer reflected in these figures. It seems thus, that the effects of freezing are not conspicuous, as far as these results will be kept as a standard of judgment when discussing the effects of frost on soil structure. The results from water retention analyses, according to which freezing did not increase the water content retained by soil, actually already indicated this type of behaviour of soil.

On the other hand, it may be possible that freezing particularly at the highest soil water potentials has to some degree eliminated the collapsing effect which had existed without the preventing effect of ice. It is probable that the process that has formed these aggregates - a slow drying inside a big clod (p. 262) - has caused the positions of primary and/or secondary particles inside the clod to become instabile to a certain degree. The water brought into this system apparently has caused this instabile system to totter and the particles have moved closer to each other making the aggregate more dense. If no freezing was involved in the process, it is possible that the collapse had been even more drastic.

\section{c. Changes of total pore volumes of aggregates after wetting and air drying}

In ideal cases the wetting and the subsequent air drying will cause no changes in total pore volumes and, thus, the pore volumes before and after the treatment are equal. In this case the amount of water added to the soil has no significance to the result.

The aggregates studied here do not represent sideal soil». Moistening and 
Table 18. Changes of total pore volumes $\left(\Delta \mathrm{V}_{\mathrm{p}}\right)$ in percentage units at one moistening and air drying procedure at four soil water potentials (bar).

\begin{tabular}{rrrrr}
\hline Sample & -0.02 & -0.1 & -1.0 & -15.0 \\
\hline $\mathrm{C} 1$ & $4.3^{\mathrm{a}}$ & $3.4^{\mathrm{ab}}$ & $2.1^{\mathrm{bc}}$ & $1.2^{\mathrm{c}}$ \\
$\mathrm{C} 2$ & $3.7^{\mathrm{a}}$ & $3.0^{\mathrm{ab}}$ & $1.5^{\mathrm{b}}$ & $-0.2^{\mathrm{c}}$ \\
$\mathrm{C} 3$ & $3.6^{\mathrm{a}}$ & $2.5^{\mathrm{b}}$ & $1.4^{\mathrm{e}}$ & $0.0^{\mathrm{d}}$ \\
$\mathrm{C} 4$ & $2.4^{\mathrm{a}}$ & $3.1^{\mathrm{a}}$ & $2.3^{\mathrm{a}}$ & $0.2^{\mathrm{b}}$ \\
& & & & $-0.9^{\mathrm{c}}$ \\
$\mathrm{S} 1$ & $3.2^{\mathrm{a}}$ & $3.6^{\mathrm{a}}$ & $1.5^{\mathrm{b}}$ & $-0.8^{\mathrm{c}}$ \\
$\mathrm{S} 2$ & $2.8^{\mathrm{a}}$ & $1.5^{\mathrm{b}}$ & $0.6^{\mathrm{b}}$ & $-0.8^{\mathrm{b}}$ \\
$\mathrm{S} 3$ & $3.7^{\mathrm{a}}$ & $2.5^{\mathrm{a}}$ & $0.4^{\mathrm{b}}$ & $0.0^{\mathrm{b}}$ \\
$\mathrm{S} 4$ & $4.3^{\mathrm{a}}$ & $3.4^{\mathrm{a}}$ & $2.0^{\mathrm{a}}$ & \\
\hline
\end{tabular}

Means in each line followed by a common letter do not differ at $\mathrm{P}=0.05$.

air drying has clearly had a positive effect on the increase of pore volume in all the samples analyzed particularly at the potentials of -0.02 and -0.1 bar (Table 18). At the potential of -1.0 bar the increase is still obvious but at the potential of -15.0 bar the silty clay aggregates once again show a tendency of diminishing pore volumes like in the previous experiments.

According to Table 18 it is apparent that the increase of pore volume is the more remarkable the more water has been added to the soil. The differences between the two sample groups are insignificant, though their initial air dry pore volumes have differed remarkably. The pore volume formed in the aggregates by adding water thus represents probably a new equilibrium state, the arrangement of particles respecting the water content added to the aggregates.

On the basis of this equilibrium idea this wetting-drying test was decided to be continued with the same aggregates using a new wetting-air-drying procedure. An additional wetting was supposed to lead the particles into a new equilibrium state and the increase of pore volume would be still more extensive.

A new moistening was, however, possible for the silty clay aggregates only. A concrete result of the first treatment was that the heavy clay aggregates were so completely broken that a new wetting-air-drying procedure and particularly the pore volume determination was quite impossible to perform. Actually, the first wetting-air-drying treatment was thus as a procedure more effective than the figures in Table 18 allow to conclude.

The firmest heavy clay aggregates after the first wetting-drying treatment were those wetted to the potential of $\mathbf{- 1 5 . 0}$ bar and the weakest those wetted to the potential of -0.02 bar. The corresponding results were, in fact, already achieved by sievings and water drop analyses. The result according to which the silty clay aggregates withstood the wetting-drying-treatment better than the heavy clay aggregates makes it possible to conclude that the silty clay aggregates were more firm than the heavy clay aggregates. As has been pointed out previously, the disrupting mechanisms are quite different in these two soil type groups and, therefore, their firmness is not fully comparable. 
A second wetting-drying treatment with silty clay aggregates seems not to have changed very much the results achieved at the first wetting-dryingtreatment (Table 19). On the whole, there seems to have been a slight tendency to an additional increase of pore volume after the first treatment at the potentials of $-0.02,-0.1$, and -1.0 bar and a decrease at the potential of $\mathbf{- 1 5 . 0}$ bar. The differences are, however, not statistically significant.

Table 19. Changes of total pore volumes $\left(\Delta V_{p}\right)$ in percentage units at two moistening and air drying procedures in silty clay samples at four soil water potentials (bar).

\begin{tabular}{crrrr}
\hline Sample & -0.02 & -0.1 & -1.0 & -15.0 \\
\hline & & & & \\
S 1 & $4.2^{\mathrm{a}}$ & $4.0^{\mathrm{a}}$ & $1.5^{\mathrm{b}}$ & $-0.9^{\mathrm{c}}$ \\
S 2 & $3.6^{\mathrm{a}}$ & $1.6^{\mathrm{b}}$ & $0.9^{\mathrm{b}}$ & $-1.1^{\mathrm{c}}$ \\
S 3 & $3.8^{\mathrm{a}}$ & $2.6^{\mathrm{a}}$ & $0.4^{\mathrm{b}}$ & $-1.3^{\mathrm{c}}$ \\
S 4 & $5.0^{\mathrm{a}}$ & $3.9^{\mathrm{a}}$ & $3.7^{\mathrm{a}}$ & $-0.7^{\mathrm{b}}$ \\
\hline
\end{tabular}

Means in each line followed by a common letter do not differ at $\mathrm{P}=0.05$.

The purpose of the wetting-drying analysis was to establish what proportion of the increase of the total pore volume achieved by freezing treatments was due to the freezing itself and what was due to the changes caused by wetting. As can be seen from the results of these two analyses (Tables 17 and 18), there are no great differences between the increases of the pore volumes after the treatments. And, if there is some difference, the wettingdrying treatment has caused a greater increase of pore volume than the freezing-thawing-air-drying treatment. The differencens between the figures for heavy clay samples are not statistically significant, but for the silty clay samples, not S4, they are at the potential of -0.02 bar and for the sample $\mathrm{S} \mathbf{1}$ even at the potential of -0.1 bar, as appears from the following tabulation. The figures express the differences $\left(\Delta \mathrm{V}_{\mathrm{p}}\right.$ by freezing-thawing-air-drying) - $\left(\Delta \mathrm{V}_{\mathrm{p}}\right.$ by wetting-air-drying $)$ in percentage units.

$\begin{array}{rrrrr} & \text { S 1 } & \text { S } 2 & \text { S 3 } & \text { S 4 } \\ -0.02 \text { bar } \ldots \ldots \ldots . . . & -2.2^{*} & -1.8^{*} & -2.6^{* *} & -1.5 \\ -0.1 \quad \ldots \ldots \ldots \ldots & -2.4^{*} & -0.5 & -2.1 & -1.4\end{array}$

These negative figures have thus been acquired with the silty clay aggregates and the highest water potential. This result reflects first of all the differences between the bonding strength of primary/secondary particles, and more exactly the stronger intermediate bonds between clay particles than between coarser fractions. Thus the ice formation in the soils where the bonds are not very firm, e.g. in silty soils, more easily distorts the mutual bonds of particles than in soils rich in clay fraction. This results not in a greater but a smaller porosity. The factors causing this phenomenon obviously are connected not only to the formation of ice in the soil and its effects on pushing soil particles apart, but also to the water movement from the inner part of soil towards the soil surface. An additional effect is likely the amount of water frozen being in the silty clay aggregates larger than in the heavy clay aggregates. 
d. Changes of total pore volumes of aggregates after freezing and freeze-drying

If it is possible for water to escape from the soil by sublimating, the soil structure usually becomes very friable. This can be seen in the winter when the ploughed soil appears from beneath the snow layer. Sublimation may take place already in the autumn when the thin soil surface freezes during the short freezing periods by night. The weather being clear, sublimation is possible and, as a consequence a friable structure often appears in the ploughed soil surface.

Against this background, decision was made to inspect the effects of freezedrying on the increase of aggregate pore volume. It was presumed that the dependence between the total pore volume and the soil water content, reported ahead, would influence the properties of freeze-dried soils.

The increase of total pore volume has been quite strong in the freeze-dried aggregates (Table 20). It has been very clear in heavy clay aggregates at the potentials of $-0.02,-0.1$ and -1.0 bar and in silty clay aggregates at the potentials of -0.02 and -0.1 bar. At the potential of -1.0 bar the increase is in no silty clay sample statistically significant, neither the decrease of the total pore volume at the potential of $-\mathbf{1 5 . 0}$ bar.

Table 20. Changes of total pore volumes $\left(\Delta \mathrm{V}_{\mathrm{p}}\right)$ in percentage units by freezing and freezedrying procedure at four soil water potentials (bar). Freezing temperature $-5^{\circ} \mathrm{C}$.

\begin{tabular}{crrrc}
\hline Sample & -0.02 & -0.1 & -1.0 & -15.0 \\
\hline & & & & \\
C 1 & $13.1^{\mathrm{a}}$ & $11.2^{\mathrm{a}}$ & $9.8^{\mathrm{a}}$ & $4.8^{\mathrm{b}}$ \\
C 2 & $12.3^{\mathrm{a}}$ & $10.9^{\mathrm{a}}$ & $5.2^{\mathrm{b}}$ & $2.2^{\mathrm{e}}$ \\
C 3 & $11.9^{\mathrm{a}}$ & $9.1^{\mathrm{b}}$ & $6.8^{\mathrm{e}}$ & $2.1^{\mathrm{d}}$ \\
C 4 & $9.1^{\mathrm{a}}$ & $9.5^{\mathrm{a}}$ & $6.3^{\mathrm{b}}$ & $1.9^{\mathrm{e}}$ \\
& & & & $-0.6^{\mathrm{e}}$ \\
S 1 & $5.4^{\mathrm{a}}$ & $5.2^{\mathrm{a}}$ & $2.0^{\mathrm{b}}$ & $-0.2^{\mathrm{e}}$ \\
S 2 & $4.8^{\mathrm{a}}$ & $4.1^{\mathrm{a}}$ & $0.9^{\mathrm{b}}$ & $-1.1^{\mathrm{a}}$ \\
S 3 & $7.0^{\mathrm{a}}$ & $5.1^{\mathrm{b}}$ & $1.5^{\mathrm{e}}$ & $-0.1^{\mathrm{a}}$ \\
\hline
\end{tabular}

Means in each line followed by a common letter do not differ at $\mathrm{P}=0.05$.

The effects of both $-5^{\circ} \mathrm{C}$ and $-35^{\circ} \mathrm{C}$ were also in this test rather similar, and the results in Table 20 represent those achieved by freezing at $-5^{\circ} \mathrm{C}$ only. Some samples, e.g. C 2, S 1, and S 2, showed a slight tendency for the increase of pore volume to be after freezing at $-35^{\circ} \mathrm{C}$ somewhat greater than after freezing at $-5^{\circ} \mathrm{C}$. The differences were about 1.6 percentage units in average, but they were not statistically significant.

When comparing the results achieved in this test with those achieved from the measurments of wet aggregates, it can be observed that the increases of pore volumes have been almost all the way through smaller than those when measured moist. For the heavy clay aggregates this difference was about 10 percentage units at the potentials of -0.02 to -0.1 bars and for the silty clay aggregates about 6 to 8 percentage units. It is thus apparent that the pore volume of the aggregates has been greatest either when wet or frozen. 
The reason why the figures in Table 20 are smaller than the corresponding figures in Table 16 is a natural consequence of the collapse of aggregate structure after the escape of wice-skeleton" from the aggregate by sublimation. The determination of total pore volume of the aggregates in frozen state was, however, not possible because of the great sensitivity of mercury to the low temperatures and quick thawing of the frozen aggregates.

The changes in pore volume have been greater in heavy clay aggregates than in silty clay aggrgates at the corresponding water potentials. This result apparently reflects the dydnamic nature of the soils rich in clay fraction as a result of the changes in water content. Attention should be paid to the fact that the pore volume of air dry, heavy clay aggregates has been remarkably lower than that of silty clay aggregates (p. 283), but when moistened, there are no very great differences in general (Fig. 8.) The structure of this type of soil is thus strongly determined not only by the water content, but also by the conditions the soil was dried in.

When inspecting the separate results, the increase of total pore volume of sample C 1, low in organic carbon content, has been particularly at the potential of -1.0 bar remarkably stronger than that of the other heavy clay aggregates. Also at the potential of -0.02 bar there seems to be a clear difference between the samples C 1 and C 4 . This behaviour of the aggregates can obviously be explained by the difference in pore size distribution caused by organic matter. As can be concluded from Figure 6, the C 4-aggregates have contained more large pores than the $\mathrm{C} 1$-aggregates. Ice forms more easily in a large pore than in a small one, as far as water potential is concerned. The freezing temperature employed here $\left(-5^{\circ} \mathrm{C}\right)$ was, however, low enough to ensure the water to freeze in the heavy clay aggregates. A natural consequence was that the ice lense had to push away relatively more soil to grow than in the case where ice was growing in a larger pore.

In the silty clay samples there exists no such differences between the individual samples. The behaviour of the aggregates has been more uniform than in heavy clay aggregates. Only the increase of the pore volume of the sample S 3 seems to have been at the potential of -0.02 bar slightly stronger than in other silty clay samples. The clay fraction content of this sample (ca. $45 \%$ ) was about 10 percentage units higher than that of other S-samples. The reason for the uniformity of these S-samples apparently is the relatively great proportion of large pores as compared to the heavy clay aggregates, the pushing effect remaining in silty clay aggregates relatively smaller than in heavy clay aggregates. The differences in hydraulic conductivity apperently also contributes to this phenomenon.

An important phenomenon always associated with the freezing of soil is the movement of soil water due to the ice lense formation. The movement of water to the freezing front causes uneven distribution of water content within the soil, and in this case within the aggregate. When the amount of water increases on the aggregate surface it decreases inside the aggregate correspondingly. A natural consequence is that the pore volume increases according to the increasing amounts of water in the corresponding parts of soil and vica versa. 
The figures in Table 21 imply that the water movement may have some influence on the porosity of the aggregates analyzed here. They give the relative pore volumes after freezing at $-5^{\circ} \mathrm{C}$ and $-35^{\circ} \mathrm{C}$ at the potentials of $-0.02,-0.1,-1.0$ and -15.0 bar respectively. The value 100 represents the air dry pore volume.

The total pore volumes of these heavy clay aggregates seem to have diminished more steeply as a consequence of freezing at $-5^{\circ} \mathrm{C}$ than after freezing at $-35^{\circ} \mathrm{C}$ when the water potential has been decreased. When comparing the relative pore volumes, it seems that in samples $\mathrm{C} 1$ and $\mathrm{C} 2$, the pore volumes at the potential of -0.02 bar after freezing at $-5^{\circ} \mathrm{C}$ have been larger than after freezing at $-35^{\circ} \mathrm{C}$. In the samples $\mathrm{C} 3$ and $\mathrm{C} 4$ the relative pore volumes at both freezing temperatures have been equal. One reason for this may be the differences of freezing speeds together with the pore size distribution. The freezing being slow, $-5^{\circ} \mathrm{C}$, water has more time to move to the freezing front than at a fast freezing, $-35^{\circ} \mathrm{C}$. As a consequence, water cumulating as ice at the aggregate surface will increase the surface pore volume, while the diminishing water content inside the aggregate causes a decrease in the pore volume.

Table 21. Relative total pore volumes of heavy clay aggregates after $-5^{\circ} \mathrm{C}$ and $-35^{\circ} \mathrm{C}$ freezings and freeze-dryings at four soil water potentials (bar). Air dry pore volume $=100$.

\begin{tabular}{cccccc}
\hline Sample & $\begin{array}{c}\text { Freezing temp. } \\
{ }^{\circ} \mathrm{C}\end{array}$ & -0.02 & -0.1 & -1.0 & -15.0 \\
\hline $\mathrm{C}$ C 1 & -5 & 141 & 136 & 130 & 111 \\
& -35 & 136 & 135 & 131 & 108 \\
& & & & & \\
$\mathrm{C} 2$ & -5 & 133 & 124 & 114 & 111 \\
& -35 & 129 & 127 & 119 & 101 \\
$\mathrm{C} 3$ & -5 & 130 & 123 & 117 & 104 \\
& -35 & 129 & 125 & 120 & 109 \\
$\mathrm{C} 4$ & -5 & 122 & 121 & 114 & 107 \\
& -35 & 122 & 118 & 116 & 104 \\
\hline
\end{tabular}

But, as seen in Fig. 8, the increase of pore volume by increasing the water potential has in this work ceased already at the potential of -0.1 bar. Thus, the diminishing water content inside the aggregate does not necessarily mean that its pore volume would diminish to the same degree, but the outside pore volume of the aggregate may increase relatively more effectively than the inside decreases. If, however, the freezing temperature is low, water has not time to move to the aggregate surface, but the freezing will take place almost on the spot. In this case, the distribution of water is thus more even and the relative unevenesses of ice within the aggregate is less probable. As a consequence, the total pore volume is apparently slightly greater at a higher freezing temperature than at a lower freezing temperature.

According to this supposition, a low freezing temperature does not necessarily cause a greater pore volume than a higher temperature. The situation may instead be the reverse at certain circumstances. 


\section{$V$ The role of water movement due to freezing determining the change of soil structure}

In previous chapters a supposition on the effect of water movement on soil structure due to freezing was introduced, but it could not be confirmed within the limits of the tests set up. Therefore it was appropriate to study this phenomenon with specific tests. In fact, the phenomenon of water movement because of the ice formation is, however, not a new one. It has been studied in numerous papers on soil frost (KoKkonen 1924, TABER 1930, Beskow 1935, Eriksson 1941, Penner 1956, Martin 1959, Ferguson et al. 1964, Dirksen and Miller 1966, Hoekstra 1969, Miller et al. 1975, and others). Mostly these studies were concerned with inspecting deeper layers of soil, and the effects of water movement determining different frost structures below the field surface and roads as well as the effects of freezing pressures. Seldom has the object of the studies, including agricultural studies, been the soil surface and particularly the effect of soil frost and water movement connected with it in the quantitative sense. The aim of this chapter is to find out, what the effect of water movement on soil structure is, particularly the movement in small clods on the soil surface. It was supposed that the water movement has considerable effect on soil structure already in this small scale.

\section{The amounts of moved water \\ a. Measuring the amounts of moved water}

For the measuring of the amounts of water moved as the consequence of freezing a simple gravimetric method was employed. Two clod sizes were inspected: the smaller is called in this study small soil cylinder and the bigger is called big soil cylinder. The procedure of the measurement was as follows:

Sieved soil $(<2 \mathrm{~mm})$ was taken into beakers and moistened to four/five soil moisture contents, i.e, $60-50-40-35-30 \%(w / w)$. The wet soil was mixed thoroughly and the paste was let to stand for one day in a $+5^{\circ} \mathrm{C}$ room to ensure an even moisture content. For the freezing small soil cylinders were prepared by taking wet soil with a spatula into a small plastic cylinder, $25 \mathrm{~mm}$ in diameter and $10 \mathrm{~mm}$ in height. The soil was put into the cylinder as evenly as possible by filling the cylinder with small amounts of soil until it was full and levelled thereafter with a spatula over the upper edge of the cylinder.

After the filling up, the soil was removed from the plastic cylinder and a thin plastic tape of a suitable width was wound around the soil, as shown in Fig. 9. The tape was to prevent sublimation during the freezing period. The soil cylinder was placed on a styrox sheet $4 \mathrm{~cm}$ in thickness and covered with a sheet of the same size. Thereafter the soil cylinders were taken into a freezing chamber, the freezing period being two days.

The purpose of the styrox sheets was to prevent heat from escaping through the upper and lower surfaces of the soil cylinders at freezing and thus to ensure that freezing would take place only through the taped sides of the cylinder. Thus the movement of water would also be directed towards the taped surface.

Immediately after the freezing period the moisture contents of the inner part of the frozen soil cylinder $\left(10 \times 10 \mathrm{~mm}^{2}\right)$ as well as the outer part was determined. In addition, some of the soil material was employed for the determination of total pore volume after a freeze-drying period of three weeks.

The bulk density of small soil cylinders prepared from paste with a spatula was not controlled and, therefore, for studying the effects of compaction a different procedure was employed to prepare small soil cylinders. A certain amount of air dry soil, about 4.5 to $5 \mathrm{~g}$ was spread 

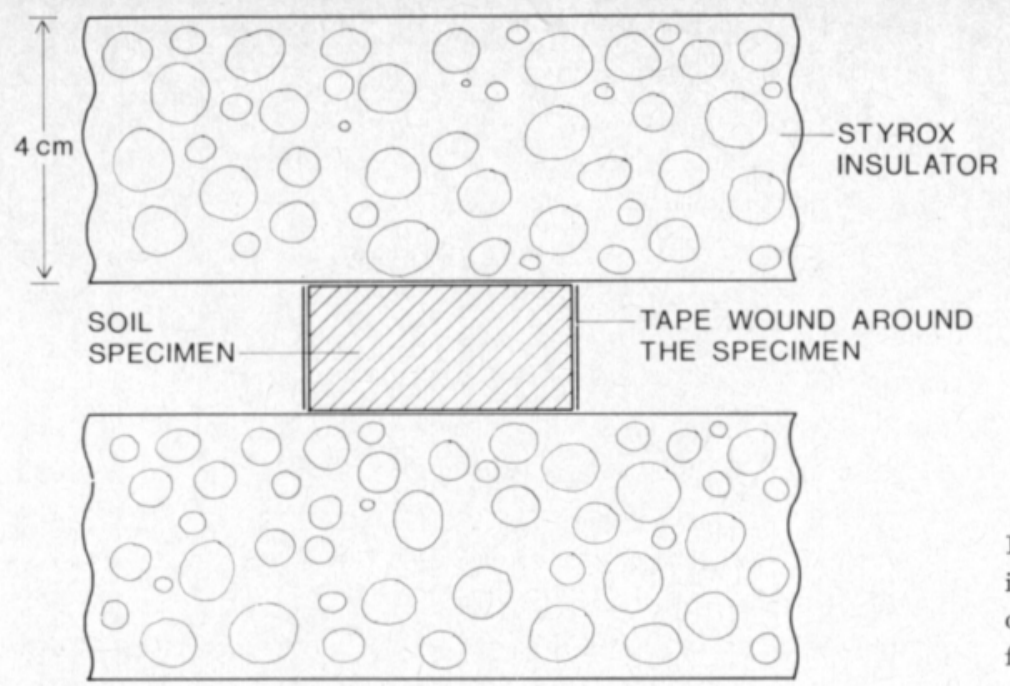

Fig. 9. Scheme of the insulating procedure of soil cylinders for freezing treatments.

in a cylinder and the amount of water calculated for a certain water content was dropped with a pipette on this soil. The moisture was let to equilibrate for about half an hour before compaction. The insulating and the freezing procedures were similar to those described above. The soil cylinders prepared with this procedure are called soil cylinders prepared as dry differing thus from the soil cylinders prepared from paste.

For the big soil cylinders the moistening was done in most cases with the method prepared as dry, but some preliminary experiments were made also with the big cylinders prepared from paste. The procedure of making the big soil cylinders prepared as dry was as follows: $140-180$ $\mathrm{g}$ of soil ground to pass a $2 \mathrm{~mm}$ sieve was taken for each specimen. A metal cylinder $85 \mathrm{~mm}$ in diameter and $35 \mathrm{~mm}$ in height was filled with this material by pouring one third on the bottom of the cylinder. Thereafter, one third of the amount of the water needed for the intended water content was dropped with a pipette carefully on the soil, moistening it thoroughly. This procedure was repeated until all the soil had been expanded. The specimen was taken thereafter into $\mathrm{a}+5^{\circ} \mathrm{C}$ room for a day to ensure the equilibrium of the moisture content in the soil cylinder. After compression the soil cylinders were sealed and insulated like the small soil cylinders and taken into a freezing chamber.

The procedure of preparing big soil cylinders from paste was similar to that of the corresponding procedure for small soil cylinders, but including in addition a compression of 1.0 bar.

Because the amount of soil material was quite abundant for the big soil cylinders, the water movement could be examined more accurately than for the small soil cylinders. Therefore, a slice of soil $22 \mathrm{~mm}$ in width was cut in the direction of the diameter from the centre of the soil cylinder. This slice was cut into pieces beginning from the mid-point of the original sample towards the edge into four soil clods about $10 \mathrm{~mm}$ in width. These clods were marked from the inside out with the letters a, b, c, d, to facilitate the inspection of the results, and they were employed for determination of the moisture contents and total pore volumes.

\section{b. Movement of water in a small soil cylinder prepared from paste}

Based on the information acquired from the field observations presented in the beginning of this study, according to which soil temperature seldom descends very much below zero, the effects of the temperatures of $-2^{\circ} \mathrm{C}$ and $-5^{\circ} \mathrm{C}$ were first studied in this test. It proved, however, that $-2^{\circ} \mathrm{C}$ was not low enough to ensure freezing in all the specimens. For example, the C 4 -soil 
cylinders did not freeze at all and only few of the C 1-soil cylinders did freeze. Also for the silty clay samples the freezing at $-2^{\circ} \mathrm{C}$ was very occasional. The non-freezing could be established first from the fact that the soil cylinders were clearly soft. But, a more clear proof of the non-freezing was, however, the fact that the movement of water was in an unfrozen soil cylinder slight, and it could be established by the moisture content determinations. Even when only partly frozen, there was a clear difference between the water contents of the outer and inner parts of the soil cylinder.

The fact that freezing at the temperature of $-2^{\circ} \mathrm{C}$ was rather occasional is probably due to the heterogenity of the small soil cylinders but, in fact, it also proves that freezing in the field may be random. Some parts of a soil clod may freeze while other parts remain unfrozen. The freezing at the temperature of $-5^{\circ} \mathrm{C}$ was more even, and therefore this lower temperature has been the main object of study in the following.

The differences between the moisture contents of the outer and inner parts of small soil cylinders, $\Delta \omega$, seem to have been quite clearly dependent on the moisture content in the beginning of freezing (Table 22). For the heavy clay samples, the order of differences at both water contents, $50 \%$ and $40 \% \mathrm{w} / \mathrm{w}$, have been logical in respect to the order of water potential at the corresponding water contents; a small water potential at a particular water content also means a small difference between the water contents (cf. Fig. 6). As to the silty clay samples, the differences in the water contents do not correspond to the soil water potential as well as in the heavy clay samples. A clear deviation from this "logical" order can be observed in the samples S 2 and S 4 at the water content of $50 \%$ : there is a remarkable difference between the water potentials at the $50 \%$ level, but the corresponding differences between the water contents in Table 22 are not significant. Not even the mutual order of the samples S 2 and S 3 is mogical" in this respect. One reason for this deviation from the logical order for the silty clay samples is apparently the high clay fraction content of the S 3 compared to other S-samples, and the exceptionally high organic carbon content of the sample S4.

Table 22. Differences in the moisture contents in percentage units $(\Delta \omega)$ between the outer and the inner parts of small soil cylinders prepared from paste. The water contents at the beginning of freezing were 50 and 40 percentages $(w / w)$ respectively and the freezing temperature was $-5^{\circ} \mathrm{C}$.

\begin{tabular}{rrrll}
\hline Water content \% & C 1 & C 2 & C 3 & C 4 \\
\hline 50 & 11.7 & 8.6 & 6.9 & 4.5 \\
40 & 4.7 & 3.6 & 1.9 & 0.4 \\
\hline 50 & S 1 & S 2 & S 3 & S 4 \\
\hline 40 & 10.8 & 7.2 & 7.8 & 7.3 \\
\hline
\end{tabular}


According to the equation of linear regression when examining the results (Fig. 10), it seems that the differences in moisture contents between the inner and the outer part of a small soil cylinder are almost linearly dependent on the water potential in the beginning of the freezing in all the samples. An important fact is the straight lines illustrating the behaviour of heavy clay soil cylinders crossing the water potential axis at about the same point, -2.0 to -4.0 bar. In the silty clay samples this crossing has taken place at the potentials of -6.3 to -7.9 bar in the samples S 1 and S 2 , and in S 3 and S 4 at about -3.2 bar. In practice this means that the water movement due to freezing has ceased at these water potentials. The differences between the S 1- and S 2samples and on the other hand, S 3- and S 4-samples apparently reflect the great significance of the organic matter content and that of the clay fraction on the hydraulic properties of these soils.
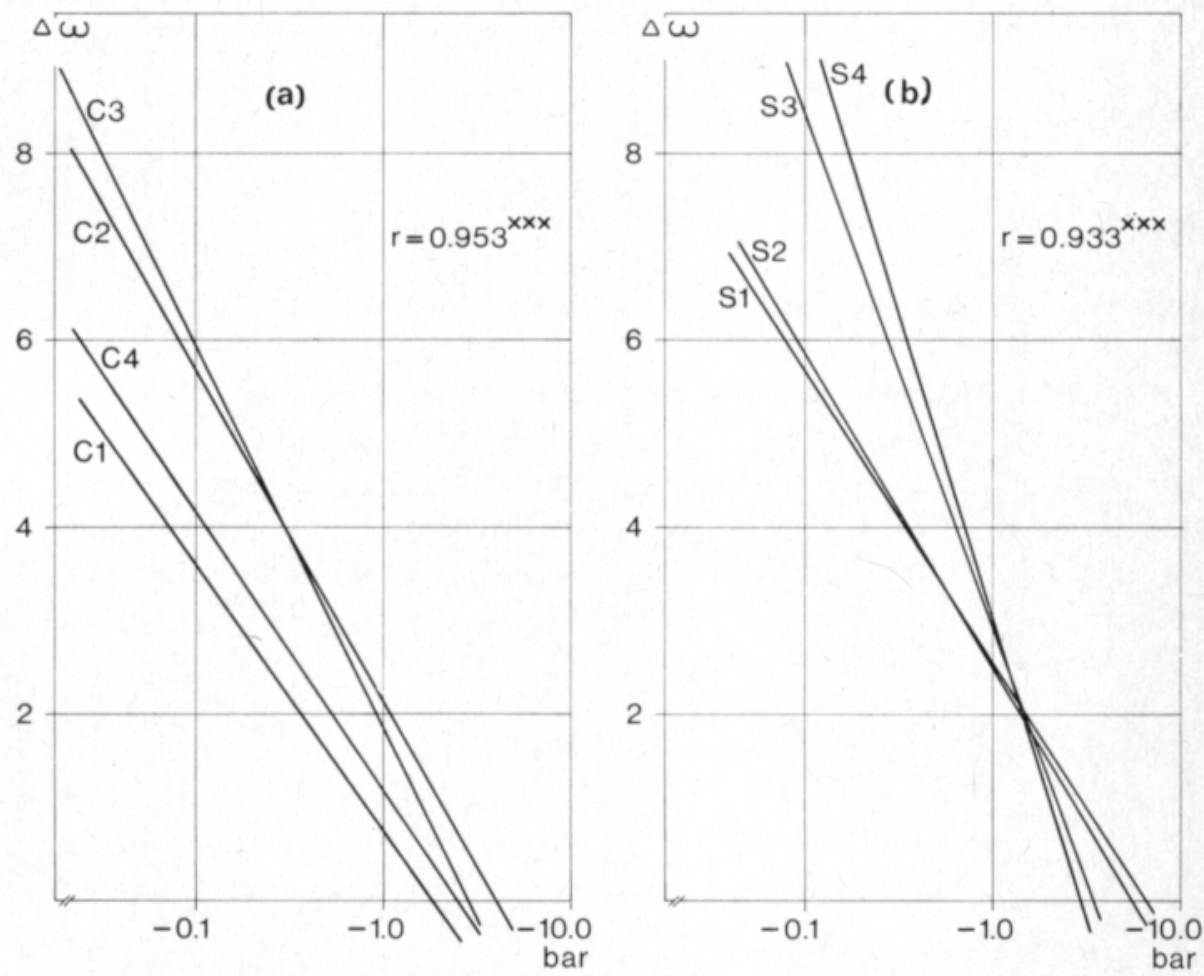

Fig. 10. Relation between the moisture content difference of the outer and inner parts of small heavy clay (a) and silty clay (b) soil cylinders prepared from paste expressed in percentage units and the soil water potential in the beginning of freezing. Freezing temperature $-5^{\circ} \mathrm{C}$.

The scanty results achieved from the $-2^{\circ} \mathrm{C}$ freezing also showed that the difference between the outer and inner parts of the small soil cylinder was also almost linearly dependent on the water potential. The correlation coefficient between these two variables was for the heavy clay soils $0.95^{* *}$ and for silty clay soils $0.93^{* * *}$. The mutual comparisons between the effects of $-2^{\circ} \mathrm{C}$ and 
$-5^{\circ} \mathrm{C}$ made on the basis of the scanty results showed a tendency for the difference in moisture content to be at the $-2^{\circ} \mathrm{C}$ freezing slightly smaller than at the $-5^{\circ} \mathrm{C}$ freezing, as can be seen in the following tabulation. The figures represent the difference $\left(\Delta \omega_{-5}{ }^{\circ} \mathrm{C}\right)-\left(\Delta \omega_{-2}{ }^{\circ} \mathrm{C}\right)$ in percentage units at four soil moisture levels:

\begin{tabular}{|c|c|c|c|}
\hline & $50 \%$ & $40 \%$ & $35 \%$ \\
\hline s 1 ..................... & & $1.8^{* *}$ & $0.8^{*}$ \\
\hline S 4 ..................... & $2.2^{* *}$ & $1.9^{*}$ & $1.5^{* *}$ \\
\hline
\end{tabular}

Indeed, the differencens are not great and it is very probable that in practice the different effects of $-2^{\circ} \mathrm{C}$ and $-5^{\circ} \mathrm{C}$ are not significant. More essential is that the soil freezes at all, and the fact that the temperature of $-2^{\circ} \mathrm{C}$ was not in all cases low enough to cause the soil to freeze justifies the conclusion that not even in practice is this temperature always low enough to cause a total freezing on the soil surface. Lower temperatures are needed.

\section{c. Movement of water in a small soil cylinder prepared as dry}

The small soil cylinders examined in the previous test were made from soil paste using a spatula and therefore the bulk density of the cylinders was not exactly controlled. In order to study the effects of compaction stage, the small cylinders prepared as dry have been taken under inspection in the following experiment.

A natural consequence of compaction is a change in the pore size distribution. This means that the proportion of large pores diminishes, which diminishing normally causes changes within the hydraulic properties (BASAK 1972, BlAKE et al. 1976, EMERSon 1978). When starting this experiment it was thus supposed that the diminishing proportion of the largest pores particularly would cause the inner parts of the soil cylinder to remain more moist in a heavier compaction than in a lighter. First the pressures of 0.1 and 1.6 bar were tried. (When tillering, the pressure caused by the tire of the tractor may exeed 1.6 bar (VANDENBERG and Gill 1962, McLeod et al. 1966)). It could be confirmed that the differences between the moisture contents of the outer and inner parts of the small C 1-soil cylinder were remarkable when the compaction was performed at the $40 \%$ soil water content and the freezing temperature of $-5^{\circ} \mathrm{C}$ : after 0.1 bar compaction the difference was $10.8 \pm 1.9$ percentage units and after the 1.6 bar compaction $6.5 \pm 1.4$ percentage units. The last figures include a source of error, i.e. when compacting at $1.6 \mathrm{bar}$, some of the water from the soil escaped and even if it was let to be reabsorbed in the soil, the results achieved apparently did not correspond to the situation where no water had escaped. Therefore, the greatest compaction pressure in most cases in the following experiments is 1.0 bar.

For the sake of comparison compaction of wet soil prepared from paste at the pressures of 0.1 and 1.6 bar was, however, tried. It seemed that the compaction did not affect the difference in moisture content between the outer and the inner parts of small soil cylinders: after compaction at 0.1 bar the difference was $5.2 \pm 1.5$ percentage units and after 1.6 bar compaction $4.7 \pm$ 
0.7 percentage units at $-5^{\circ} \mathrm{C}$ freezing. The corresponding figures at the freezing of $-2^{\circ} \mathrm{C}$ were $4.5 \pm 1.0$ and $4.0 \pm 0.9$ percentage units respectively.

It can be concluded from Fig. 10. that if the freezing of the moist soil takes place at the same percentage water content, at different water potentials, the differences between the water contents of outer and inner parts of soil are not equal. This result could also be verified with the small soil cylinders prepared as dry (Table 23). The order of magnitude of differences for the heavy clay samples moistened to the water content of $40 \%$ has been clearly dependent on the soil water potential and thus the order of the figures in Table 23 is

Table 23. Differences in the moisture contents in precentage units $(\Delta \omega)$ between the outer and the inner parts of heavy clay, small soil cylinders prepared as dry and compacted. The water content at the beginning of freezing was $40 \%(\mathrm{w} / \mathrm{w})$ and freezing temperature $-5^{\circ} \mathrm{C}$.

\begin{tabular}{ccccc}
\hline $\begin{array}{l}\text { Compaction } \\
\text { pressure bar }\end{array}$ & C 1 & C 2 & C 3 & C 4 \\
\hline 0.1 & 9.4 & 6.2 & 1.1 & 0.6 \\
0.5 & 9.2 & 6.3 & 0.9 & 0.8 \\
1.0 & 7.3 & 6.1 & 1.4 & 0.3 \\
\hline
\end{tabular}

analogical to the corresponding curves in Figure. 6. For the sample with the highest water potential, i.e. sample C 1, the difference formed has also been the largest and, vica versa, the sample C 4 with the lowest water potential gives the smallest difference. The differences between the precentages of moved water contents are also statistically significant for the samples C 1, C 2 , and C 3 at all compaction stages, the difference between the corresponding figures of C 3 and C 4 being significant at the compaction stage of 1.0 bar only.

When comparing the effects of compaction within the individual samples, it showed that out of these four heavy clay samples only in the sample C 1 the compaction of 1.0 bar had caused a smaller difference in the percentage moisture content than the lighter compaction. The corresponding differences for the other heavy clay samples were not significant.

A corresponding experiment was made with all the samples at the water potential of -0.1 bar. It showed that the differences in the water contents were for the heavy clay samples very much of the same size, about 5.4 to 6.9 percentage units, except for the sample C 2, where the difference was $\mathbf{8 . 5}$ percentage units. For the silty clay samples it seemed that the difference was at light compaction $(0.1 \mathrm{bar})$ slightly greater than at heavier compaction. The differences were, however, not statistically significant. For the samples S 1 and S 2 they were about 6.0 to 8.0 percentage units, being thus of the same size as for heavy clay samples. For the samples S 3 and S 4 the corresponding differences were about 9.5 to 12.5 percentage units.

Freezing temperature had no effect on the moisture content difference provided that freezing on the whole took place. This result could be verified by adding to the experiment described above a temperature factor consisting of three different temperatures, i.e. $-2^{\circ} \mathrm{C},-5^{\circ} \mathrm{C}$, and $-10^{\circ} \mathrm{C}$. The effects of 
$-5^{\circ} \mathrm{C}$ and $-10^{\circ} \mathrm{C}$ were the same for all the eight samples. The freezing temperature being $-2^{\circ} \mathrm{C}$, all the four parallels of samples C 1, C 2 and S 3 only were frozen (pressure of compaction 0.5 bar). When freezing had taken place, no differences in the results could be observed as compared to those achieved by the $-5^{\circ} \mathrm{C}$ or $-10^{\circ} \mathrm{C}$ freezings.

Earlier in this work, when the effects of freezing temperatures on the changes of pore volumes of the 5-10 mm aggregates were under discussion (p. 293), it was assumed that by very fast freezing $\left(-35^{\circ} \mathrm{C}\right)$ the water simply has no time to move towards the soil surface, but freezes at the very spot. This is possible especially when the soil clod is small. Unfortunately, this

Table 24. Differences in the moisture contents in percentage units $(\Delta \omega)$ between the outer and the inner parts of small soil cylinders prepared as dry at two compaction stages. The water potential at the beginning of freezing was -0.1 bar and freezing temperature $-40^{\circ} \mathrm{C}$.

\begin{tabular}{ccccc}
\hline $\begin{array}{c}\text { Compaction } \\
\text { pressure bar }\end{array}$ & $\mathrm{C} 1$ & $\mathrm{C} 2$ & $\mathrm{~S} 1$ & $\mathrm{~S} \mathrm{2}$ \\
\hline & & & & \\
0.1 & $9.5 \pm 1.3$ & $11.3 \pm 1.3$ & $9.4 \pm 0.7$ & $9.7 \pm 2.4$ \\
1.0 & $7.9 \pm 1.0$ & $10.5 \pm 1.4$ & $9.2 \pm 0.6$ & $7.7 \pm 2.6$ \\
\hline
\end{tabular}

assumption seems not to be quite true, but the figures in Table 24 prove that the water movement due to freezing is a surprisingly fast process taking place in a rather small soil clod even at very low temperatures.

Even at the moisture potential of -1.0 bar some movement of water took place as a consequence of the fast $-40^{\circ} \mathrm{C}$ freezing. The compaction pressure had no effect in these circumstances on the moisture content difference but, on the contrary, it was surprising that the figures achieved here agree with the values that can be calculated from the regression lines in Figure 10. The differences acquired in this experiment were for heavy clay samples 0.9 to 2.2 percentage units, mean 1.5 , and for silty clay samples 0.9 to 2.8 percentage units, mean 2.2. According to this, it seems that when freezing, the forming of ice is the dominant process that affects more e.g. the movement of water than the other factors connected with it, e.g. the freezing temperature or the soil water potential (HOEKSTRA 1969).

\section{d. Movement of water in a big soil cylinder}

In the autumn the surface of a ploughed clay field mostly contains rather big clods. The disruptive effects of freezing is thus mainly directed to these big clods rather than to the smaller ones. Therefore, the big soil cylinders were taken under inspection in order to simulate more accurately the conditions in the field than when employing the small soil cylinders mentioned in previous chapters.

This inspection is mainly concerned with soil cylinders prepared as dry. The scanty results of the water movement and thus also the pore volumes in big soil cylinders prepared from soil paste are still very preliminary. In the following studies the main objects of inspections will, however, be the big 
soil cylinders prepared from paste, because the soil ploughed in the autumn more often resembles soil paste than fine ground dry soil.

The moisture distribution in big soil cylinders prepared as dry has changed very clearly as a consequence of a one-week freezing $\left(-5^{\circ} \mathrm{C}\right)$ (Fig. 11). In the silty clay samples the change seems stronger than in heavy clay samples, which result is analogous to the results achieved for the small soil cylinders. Compaction seems not to have had any remarkable effect on the moisture contents in different parts of the soil cylinder, though there is a tendency that the stronger compaction causes slightly smaller moisture content differences between the inner and the outer parts of cylinder than the lighter compaction. In fact, this result is more obvious than can be decided from the figures. Especially at lighter compaction, in some cases some water moved to the outer surface of soil cylinder was fastened as ice to the plastic tape around the cylinder. When the tape was removed before cutting the soil, some ice was also removed from the surface ice layer. Because of the irregularity of the fastening, the amounts of ice lost this way from the soil have never been attempted to calculate, and has therefore not been taken into consideration in the figures. In general, the amounts of ice removed were, however, so small that they hardly had any great effect on the percentage figures given. In heavier compaction the amounts of ice fastened were remarkably smaller; in most cases there was no ice.

The very similarity of the curves in both soil type groups and in both compaction levels is worth noticing. An interesting feature is that neither for the heavy clay samples nor the silty clay samples has the shape of the curves been affected by the moisture content when freezing has started and, as a consequence, the difference in the moisture contents between the outer and the inner parts of the cylinders has not changed very much especially for the heavy clay samples. Once again the mutual similarity of the behaviour of the samples S 3 and S 4 is conspicuous despite their dissimilarity with regard to particle size and organic carbon content.

An essential factor affecting the structural formation of big soil clods due to freezing is apparently the accumulation of water in a rather thin layer on the soil surface. In all the samples studied here, the thickness of the layer, where the water content has exceeded the initial water content at freezing (a small arrow $\rightarrow$ on the curve), has been about 12 to $14 \mathrm{~mm}$. The thickness of this layer has been about the same in both of these soil type groups, though it seems that it may have been slightly thinner in the silty clay samples. It is probable that just this accumulation of water on a thin soil clod surface is anvessential factor causing the well aggregated and friable structure of soil surface in a ploughed field.

The inner parts of these big soil cylinders have dried very uniformly as was the situation with the small soil cylinders. When the moisture contents of the inmost parts of the cylinders are compared with the corresponding contents in the water retention curves (Fig. 6), it can be noticed that particularly the inner parts of the heavy clay soil cylinders have dried to about the same water potential, -1.3 to -2.0 bar. The samples S 3 and S 4 seem to have remained somewhat moister. 

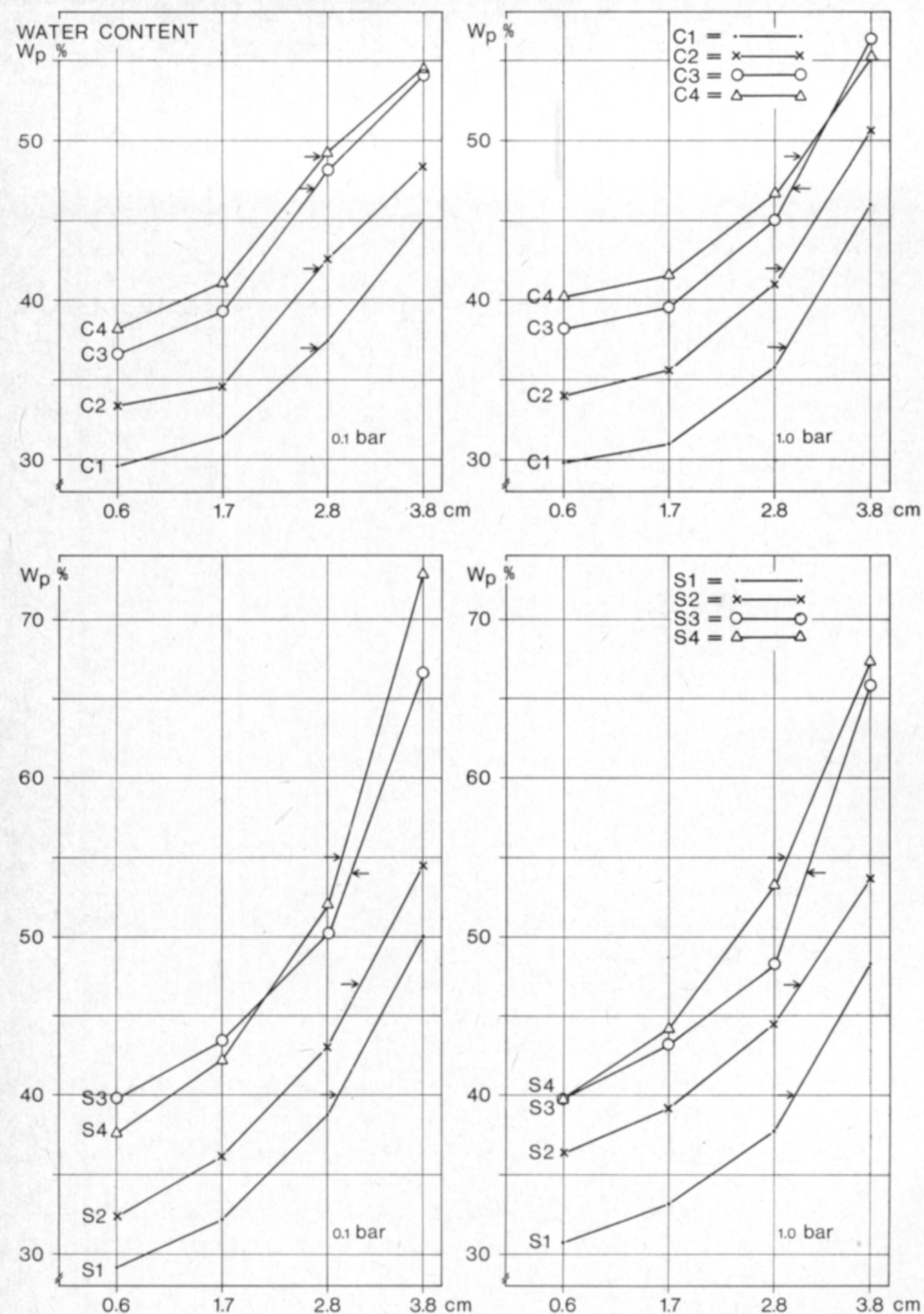

Fig. 11. Movement of soil water in the big heavy clay and silty clay soil cylinders prepared as dry and compacted with pressures of 0.1 and 1.0 bar respectively. Time of freezing 1 week, freezing temperature $-5^{\circ} \mathrm{C}$ and water potential in the beginning of freezing -0.1 bar. The small arrow $\rightarrow$ by the curve indicates the water content in the beginning of freezing and $\mathrm{cm}=$ the distance from the centre of soil cylinder. 
The freezing time employed in this experiment was one week to ensure full freezing of the soil cylinder. A remarkably shorter freezing time would, however, have been long enough for the same effect. This could be confirmed by studying the freezing time needed for water to move as a result of freezing. The basis for this inspection was that the first freezing weathers in the autumn, occurring most often at clear nights, generally do not last very many hours.

The procedure of this experiment was a repetition of the above, except that the freezing $\left(-5^{\circ} \mathrm{C}\right)$ lasted 3,6 , or 16 hours. (18 hours for the big soil cylinders prepared from paste). The freezing time of 3 hours has already caused a clear movement of water inside the soil cylinder (Fig. 12) and there are no great differences between the shapes of the individual curves, though the percentage of water contents in the beginning of freezing $(\rightarrow)$ differ remarkably. A 6-hour freezing has already caused perceptible bending of curves particularly for the samples C 1 and C 2 which are high in clay fraction content and low in organic carbon content. This obviously means that the movement of water has diminished, while in the coarser soil S 1 this phenomenon is not so evident. A natural consequence of the longer freezing time further seems to be a slightly thicker accumulation layer in the 6-hour freezing than in the 3-hour freezing. The curves of a 16-hour freezing already resemble very much those after one week of freezing and, when examining the thicknesses of the accumulation layers, it seems that the effects of one-week freezing and 16-hour freezing have been in this respect quite similar. The freezing time exeeding 16 hours, had thus no additional effect on the movement of water within the soil clods of the size analyzed.

The movement of water in big soil cylinders prepared from paste seems not to differ very much from the heavy clay samples prepared as dry the preliminary tests were made on (Fig. 13). In addition to that the difference in the water content between the outer and the inner parts of soil cylinder is a function of the water content of the cylinder in the beginning of freezing, it still seems obvious that the difference formed was not in these paste made cylinders as great as in the cylinders prepared as dry. This, in fact, is apparently due to the greater hydraulic conductivity in the latter. But nevertheless, a rather short freezing (three hours) has already caused also in these relatively homogeneous samples clear water movement. Indeed, this factor, the moving of water to the clod surface as a consequence of a relatively short freezing period may be one of the most essential factors determining the soil surface structure. Apparently, this may be more important than whether an equilibrium in the water movement has been reached or not. 

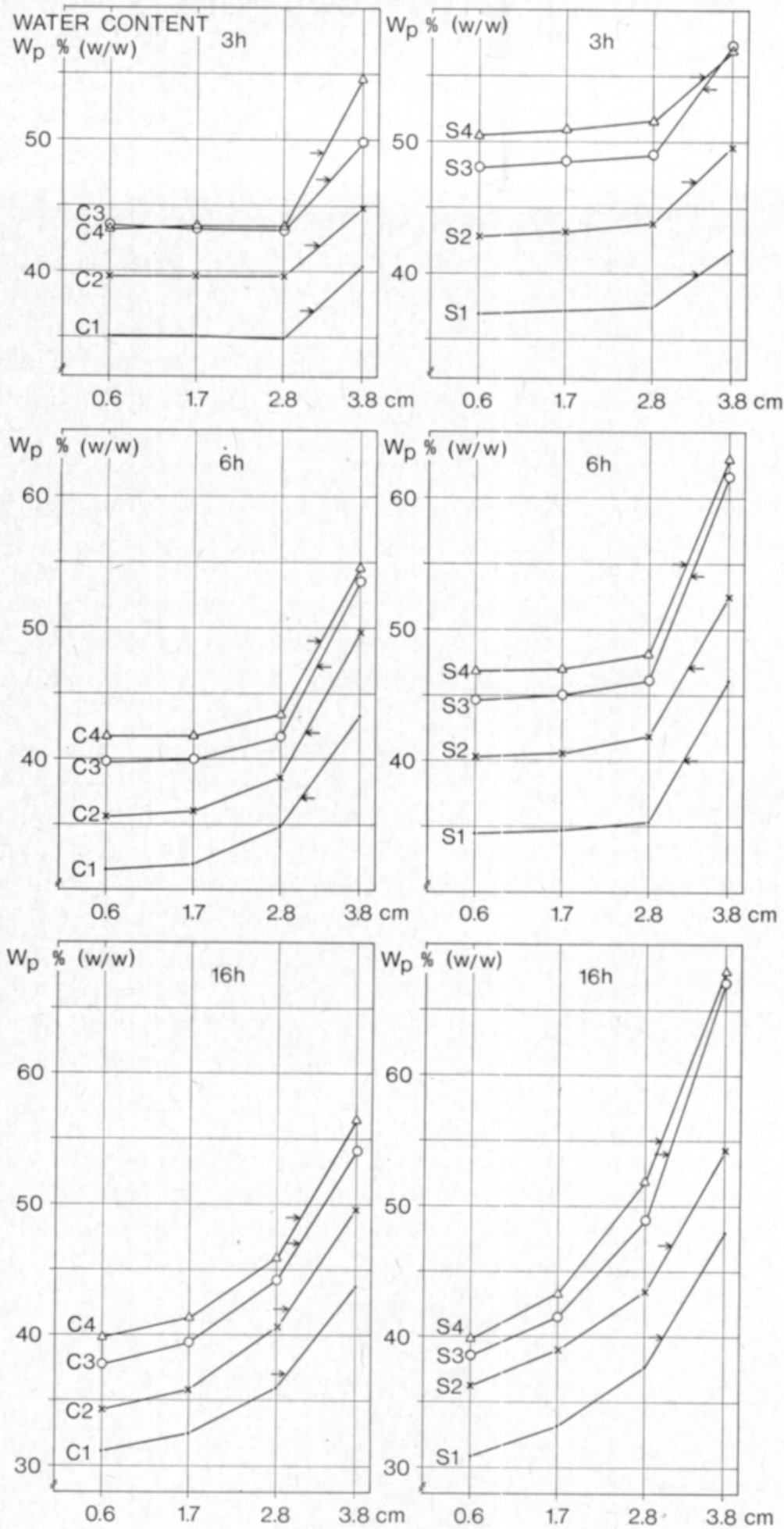

Fig. 12. Effect of $3-6-16$-hour freezings at $-5^{\circ} \mathrm{C}$ on the movement of water in the big soil cylinders prepared as dry. Freezing temperature $-5^{\circ} \mathrm{C}$ and water potential at the beginning of freezing -0.1 bar (the small arrow $\rightarrow$ by the curve). 

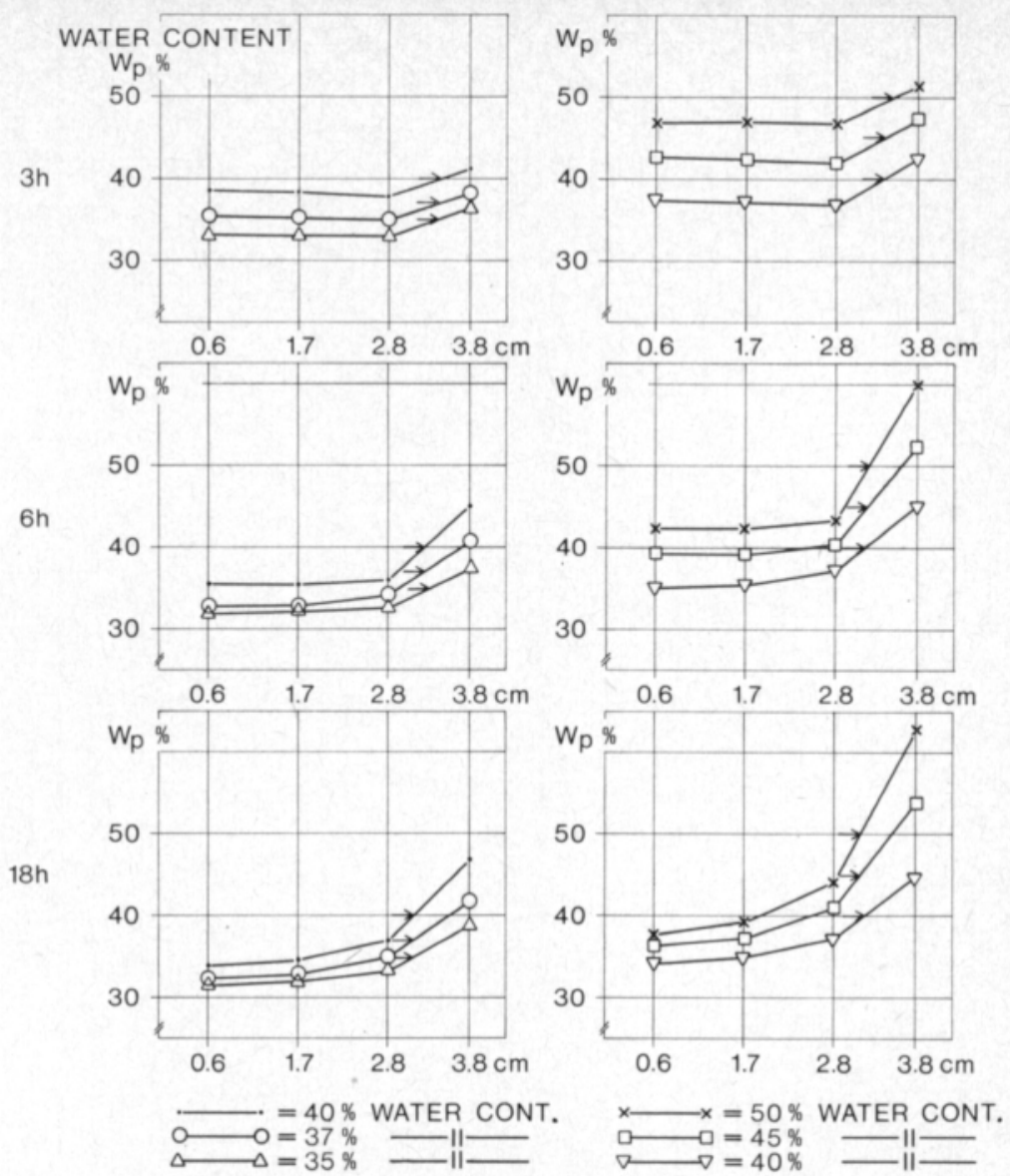

Fig. 13. Movement of soil water in the big $\mathrm{C} 1-$ and $\mathrm{C} 2-$ soil cylinders prepared from paste at three different soil water contents and three different freezing periods. The small arrow $\rightarrow$ by the curve indicates the water content in the beginning of freezing. Freezing temperature $-5^{\circ} \mathrm{C}$.

2. Effect of watermovement on the total porevolume of soil cylinders

Earlier in this study, it has been proved that the pore volume of aggregates is strongly dependent on the moisture content (p. 283). It was, therefore, supposed that the remarkable changes in the water contents of the soil cylinders measured in the former chapters, probably affect the porosity properties too: the accumulation of water increases the porosity of the outer surface of soil cylinder, while the decreasing water content inside the cylinder has a diminishing effect on the total pore volume.

The total pore volume determinations were made from the corresponding soil cylinder parts as the moisture content determinations after a three-week freeze-drying. Furthermore, total pore volumes were determined also for soil cylinders air dried without any freezing treatments. 
a. Effect of water movement on the total pore volume of small soil cylinders

The differences in the water contents between the outer and the inner parts of soil cylinders were remarkable in all the samples, especially when the water potentials were highest (Fig. 10, Table 22). This fact seems, however, not to have had very great effect on the total pore volumes of these parts of the soil cylinders but these differences seem to be rather small, especially in the heavy clay cylinders (Fig. 14). In the silty clay samples the total pore volume differences between the outer and the inner parts of cylinders seem to be slightly more evident. According to this, the disruptive effect of the accumulation of water on the outer parts of the soil cylinder together with the diminishing water content in the inner parts of the cylinder, is thus not very probable.

But on the contrary, more essential, as far as the structure of soil cylinders and that of clay soils in general are concerned, is that the pore volumes, both of the outer part $\left(\mathrm{V}_{\mathrm{r}}\right)$ and the inner part $\left(\mathrm{V}_{\mathrm{i}}\right)$ have been significantly greater than the pore volume of air dried soil cylinder $\left(\mathrm{V}_{\mathrm{o}}\right)$, when the soil has been treated as wet. According to Figure 14, the conception wet can be understood in this case to cover the water potentials from -0.001 to about -1.0 bar. Within these water potentials the air dried specimens analyzed have been significantly dense compared to the frozen specimens. It can be concluded from Figure 14 that the influence of freezing has been efficient and, moreover, it has been the more effective the more wet the soil has been. Actually this result is not a new one among the studies on soil frost, but this result confirms the fact that each curve representing both the inner and the outer total pore volume of specimens have a point of minimum at about the water potential of -0.34 to $-\mathbf{1 . 0}$ bar. In practice this means that the soil compaction at this water potential is the most detrimental as far as the tillering effect of freezing is concerned. Even compaction of very wet soil is not so dangerous because of the greater effectiveness of freezing - which effectiveness is not limited to the clod surfaces only, but it extends to the inner parts of clods as well.

When the soil becomes drier the movement of water diminishes. At the same time the positive effects of freezing will also diminish. In a dry soil, water potential below -1.0 bar, the effects of freezing have thus been nonsignificant, but the compaction has not had as detrimental an effect as in wet soils.

In the former experiment the soil compaction was made with a spatula when the soil cylinders were made from soil paste and thus the compaction degree was not exactly controlled. The effect of water movement on the determination of pore volume was also observed at the conditions the compaction pressure was controlled (Fig. 15). The total pore volume of the outer part of soil cylinder prepared as dry has been remarkably greater than the pore volume of the air dried soil cylinders at all compaction levels studied. The total pore volume of the inner part of the cylinder has been only for the samples C 1 and C 2 greater than the pore volume of air dried cylinders and, in this respect, the results achieved with these soil cylinders are not quite analogous to the results from the former experiment in which soil paste was employed. 

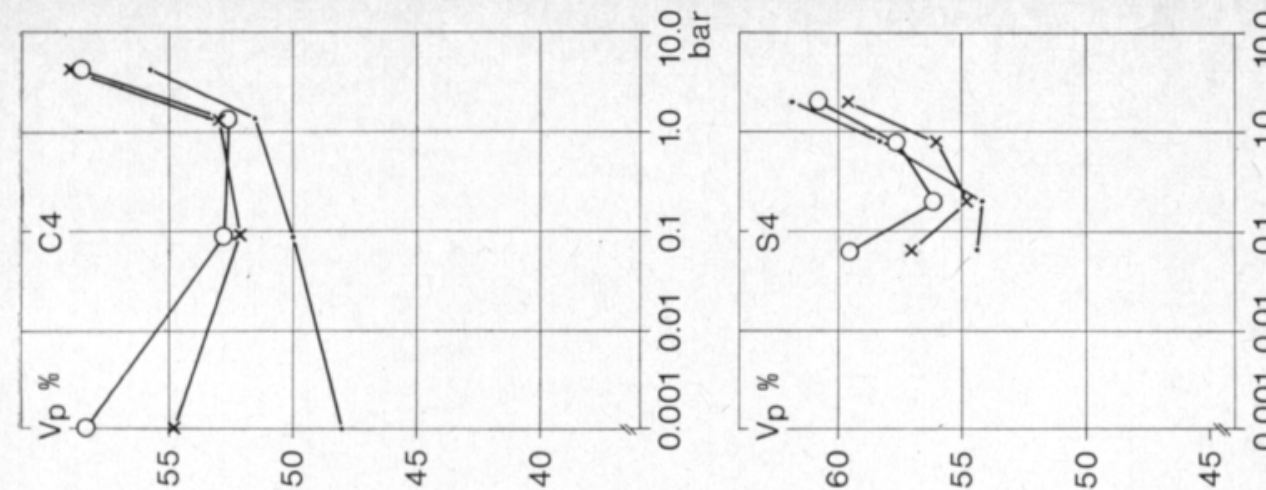

으음

은 苞先

-

-

용

5 융

돈

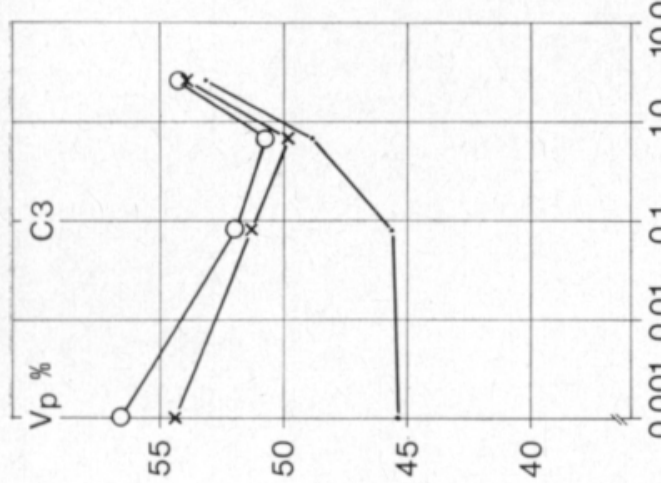

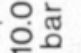

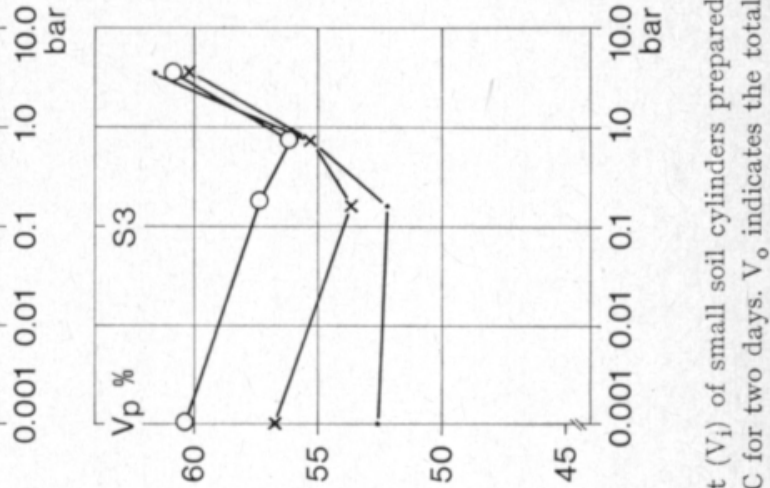

응 해 쥬
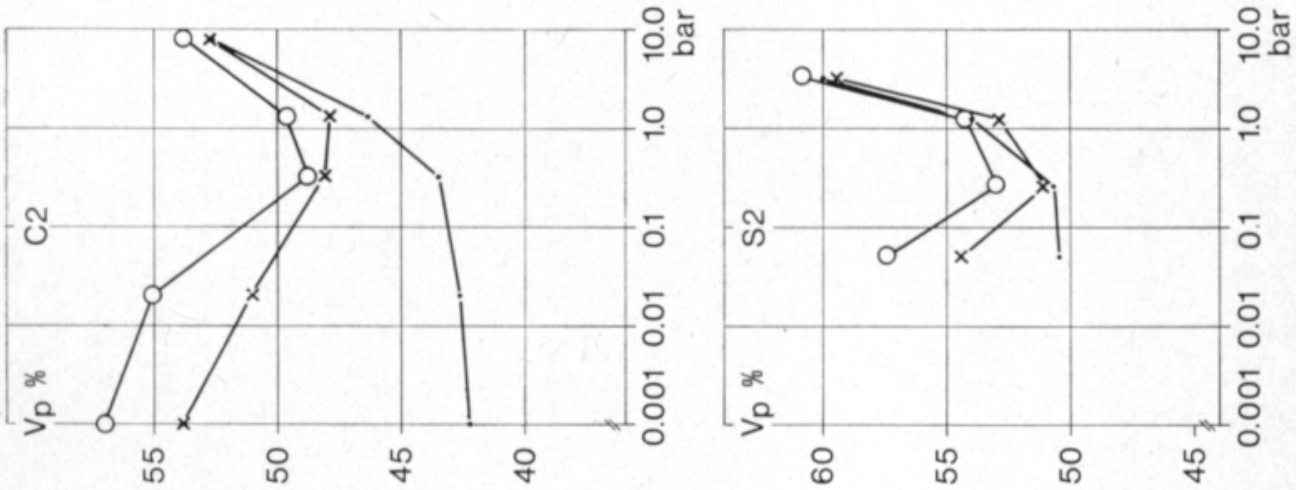

난은

है

․․

‡. 胥

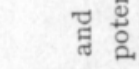

अ

-

岁蓪

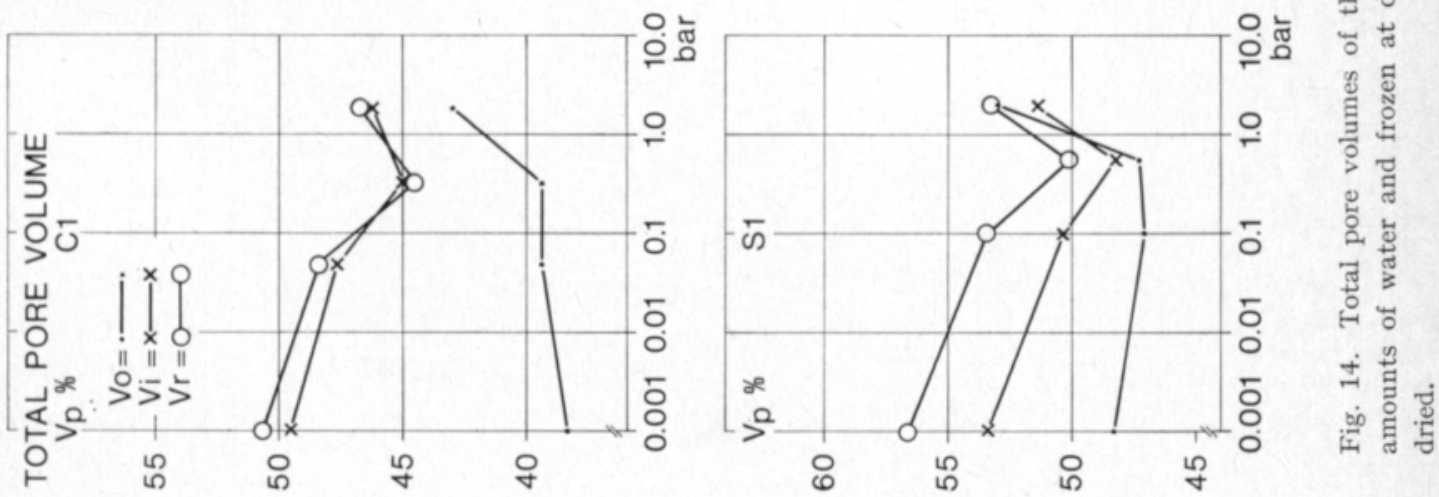




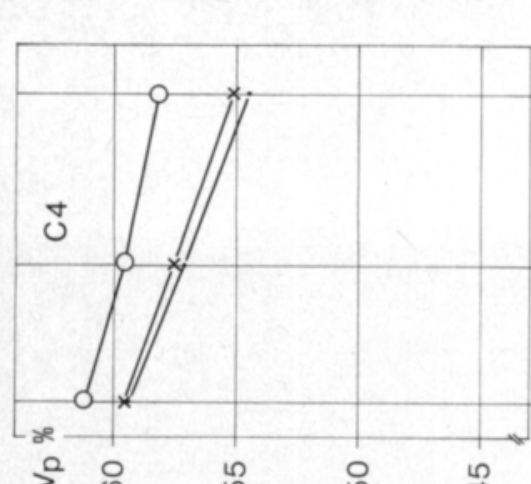

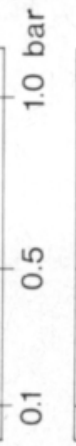

อั้

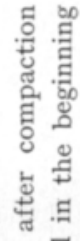

ก)

疍

g
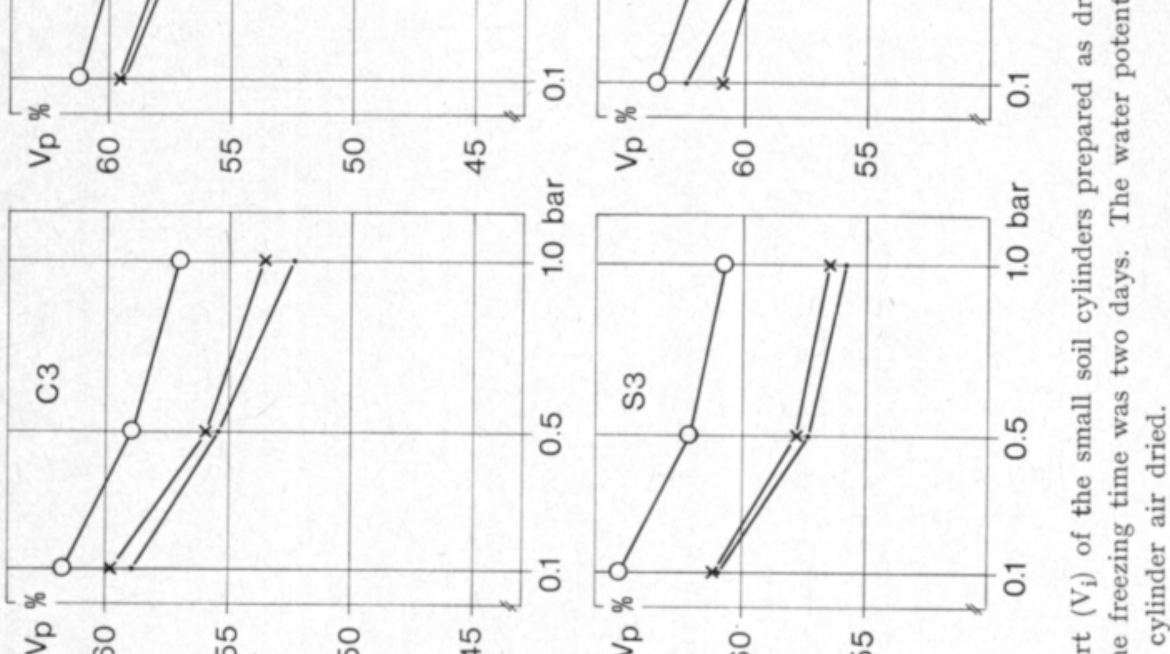

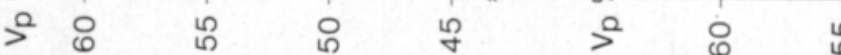
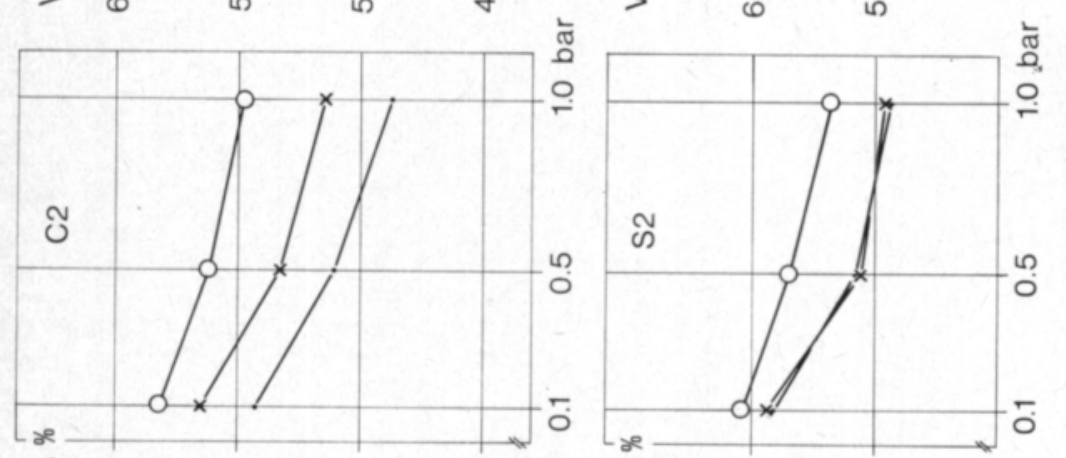

范 击

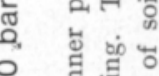

ฏ

올

淽莒

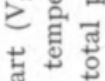

ผ 0

s. in

。 1 \&

$>0$ 유

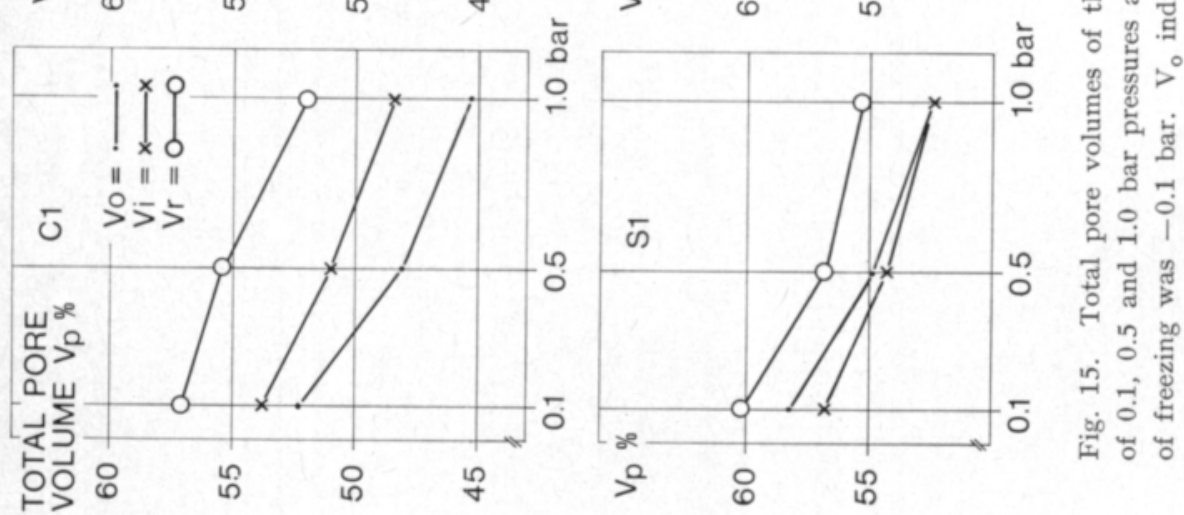


It is conspicuous that among the heavy clay samples compaction has been the more drastic the smaller the organic carbon content has been. But on the other hand, also the loosening of the soil has been greater in these soils low in organic carbon content than in the soils containing more organic carbon. The reasons for this are apparently the same as expressed earlier in this work in connection with the inspections of the effects of freezing on the total pore volumes of aggregates (p. 292). This apparently is also the reason for the slight tendency that the increase of total pore volume has been relatively greater after a heavy compaction than after a lighter one.

According to Figure 15, it could be concluded that particularly in the heavy clay soils the soil structure reverts to its original state, or about to the same, surprisingly quickly. It can be observed that within some samples the $\mathrm{V}_{\mathrm{r}}$ at 1.0 bar compaction has been of about the same size as the $\mathrm{V}_{\mathrm{o}}$ after 0.1 bar compaction. It may be obvious that the reverting is still stronger in actual field conditions, because the results given in Figure 14 make it possible to conclude that the effects of freezing are apparently still stronger if the soil is in the form of soil paste. And this, in fact, is the case most often in Finnish fields at the time ploughing takes place. It seems thus, according to this experiment, that the damages of compaction existing in the clay fields after ploughing in the autumn are not very dangerous because of the quick reverting as the consequence of freezing and water movement.

\section{b. Effect of water movement on the total pore volume of big soil cylinders}

The great differences in the water contents within the different parts of the big soil cylinder as the consequence of one-week freezing (Fig. 11) have
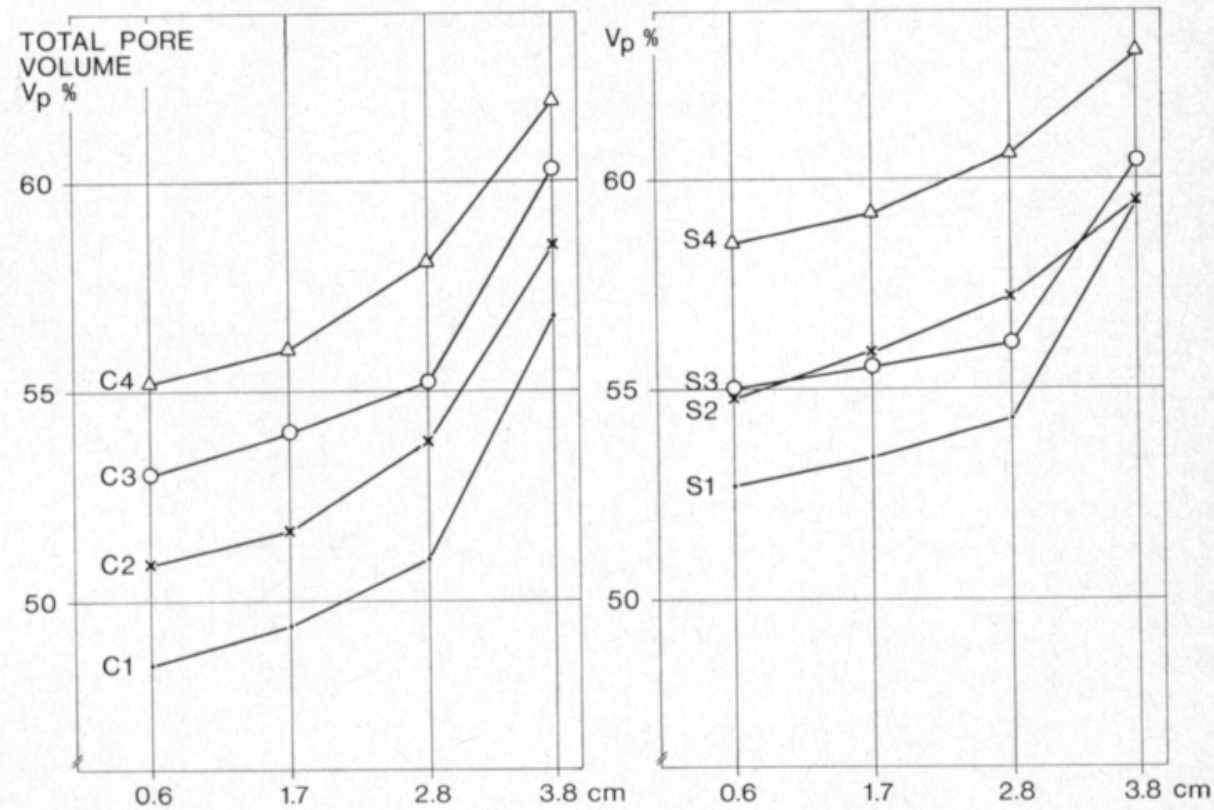

Fig. 16. Total pore volume distribution in the big soil cylinders prepared as dry, after 1.0 bar compaction and $-5^{\circ} \mathrm{C}$ freezing. Freezing time one week, and soil water potential in the beginning of freezing -0.1 bar. 
reflected also on the corresponding pore volumes (Fig. 16). The total pore volume determinations have been made in this case from the corresponding soil clods as the moisture contents presented in Figure 11, but after freeze-drying. The pore volume curves of the heavy clay cylinders are very similar in shape to the corresponding water content curves indicating that the change in water content has clearly affected the total pore volume of big soil cylinders, too. The corresponding curves of the silty clay samples are not so similar in shape. A remarkable increase in the water content in the surface of the silty clay cylinder has not caused an increase of the total pore volume to the same degree as the smaller amount of water in the heavy clay cylinders. In general, the changes of the total pore volumes have been smaller in the silty clay samples than the heavy clay samples, which result already has been achieved with earlier experiments in this study.

The different magnitudes of pore volume increases appear also from the figures calculated on the basis of this experiment, showing what the increase of total pore volume is, expressed as percentage units, if the water content increases with one percentage unit. The following ratios were achieved on the basis of the corresponding differences in moisture content and total pore volume of the soil pieces $\mathrm{c}$ and $\mathrm{d}$ :

\begin{tabular}{cccccccc}
$\mathrm{C} 1$ & $\mathrm{C} 2$ & $\mathrm{C} 3$ & $\mathrm{C} 4$ & $\mathrm{~S} 1$ & $\mathrm{~S} \mathrm{2}$ & $\mathrm{S} \mathrm{3}$ & $\mathrm{S} 4$ \\
\hline 0.56 & 0.47 & 0.46 & 0.46 & 0.48 & 0.25 & 0.25 & 0.17 \\
\hline
\end{tabular}

These figures indicate that the water movement in the samples S 2, S 3 and S 4 has not had as great an effect on the increase of the total pore volume as the other samples have had. It is to be noticed that sample S 1, where the organic carbon content is the lowest among the silty clay samples, differs from the other silty clay samples. This result is true also with sample C 1 of the heavy clay samples, the ratio reflecting the increase of pore volume being slightly stronger than that of the other.

This result is obviously due to the important role of organic matter determining the pore size distribution. Figure 6 already showed that the proportions of large pores in these two samples were, according to the classical definition, smaller than that of the other samples. It has been pointed out earlier that the relative increase of the pore volume due to freezing, will be in soils with less organic carbon greater than in soils rich in organic carbon. This, because of the lack of large pores. The greater proportion of large pores originally in the other heavy clay samples than C 1 , or the other silty clay samples than $\mathrm{S} 1$ is therefore a reason why the rations have remained smaller.

The preliminary results of the analysis of the big soil cylinders prepared from soil paste showed also a significant increase of total pore volume according to the change of water content because of freezing (Fig. 17). An important result of this experiment is that, in spite of the heavy compaction (1 bar), even the inner parts of the soil cylinders have been remarkably more porous than the corresponding soil cylinders air dried at room temperature. These 
$6 \mathrm{~h}$
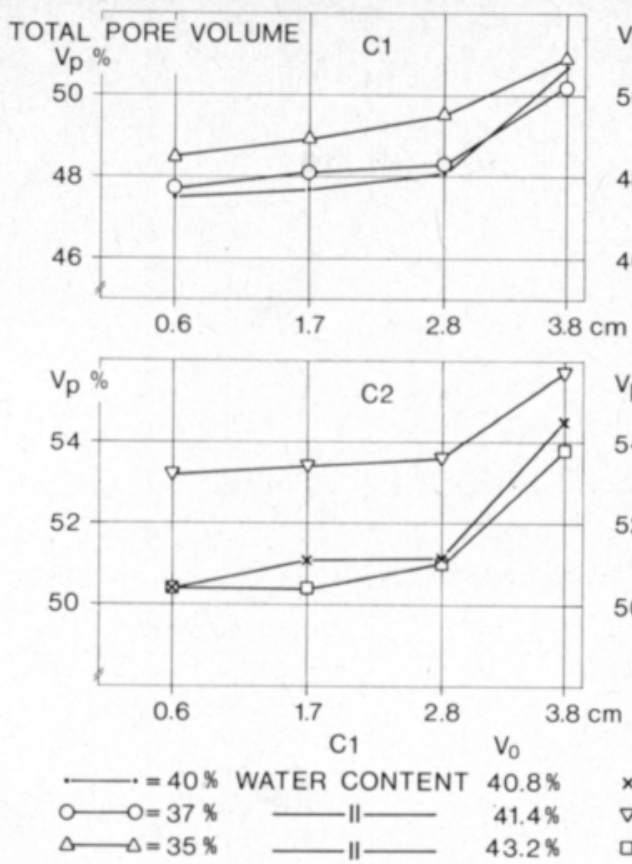

$18 \mathrm{~h}$
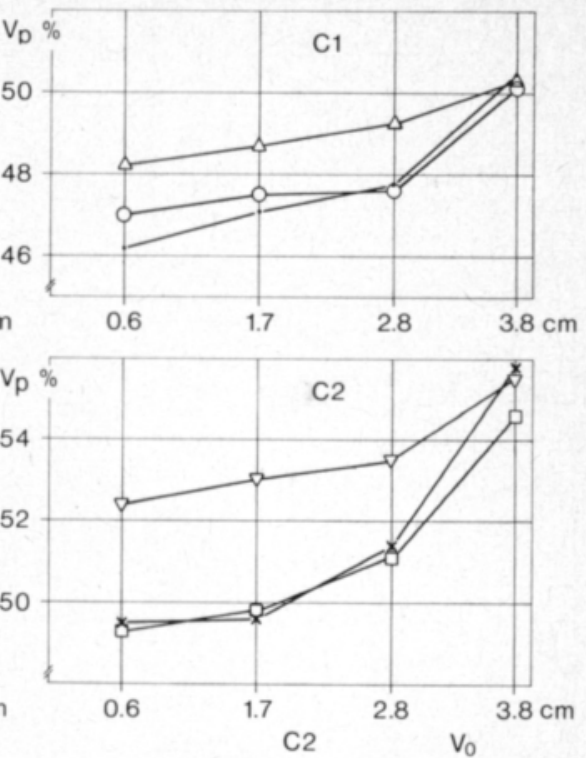

$x-x=50 \%$ WATER CONTENT $44.2 \%$

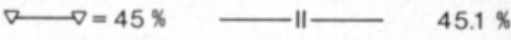

$\square=40 \% \quad 48.6 \%$

Fig. 17. Total pore volume distribution in the big C 1- and C 2- soil cylinders prepared from paste at three different soil water contents after 1 bar compaction and 6- and 18- hour freezing at $-5^{\circ} \mathrm{C} . \mathrm{V}_{\mathrm{o}}$ indicates the total pore volume of the corresponding specimen not frozen but air dried.

preliminary results thus confirm the suppositions presented ahead that freezing has positive effects on the inner parts of the soil clods, too, in spite of the escape of water due to freezing. 


\section{Discussion}

In Finland soil frost is considered one of the most significant factors affecting soil structure. According to a generally accepted opinion, it has positive effect on soil. This opinion is based on the yearly experience that the tillering properties of clay soils change considerably during the winter, this change being mostly positive. The deduction is apparently justified, although in practice it is difficult to find a field where the frost had not affected the soil. Thus there is normally lack of objects of comparison.

The above observations have been sustained by numerous field experiments. According to Czeratzki (1971), soil frost as a breaking factor of heavy clay clods is by far the most effective factor affecting the soil surface in these climatic conditions. Also the field experiments performed in this study confirm the great significance of freezing. The field experiment set up for the winter19771978 showed that the samples taken in the autumn were remarkably harder than the spring samples. In addition it showed that any measures on the soil to change the effects of soil frost, e.g. covering with straw or plastic or keeping the soil clean from snow, did not enhance the positive effects of frost, but rather deteriorated its tillering properties.

The effects of freezing seem thus to be quite obvious if the situation is being observed in the field or in the laboratory as far as the analysis includes only a qualitative evaluation of the effects of the frost. One of the greatest difficulties in this study was to find a suitable method to measure the effects observed in the field quantitatively and to explain the mechanism of the processes. It seems that the authors dealing with the effects of freezing content themselves with presenting the qualitative results of the analyses without trying to explain the mechanism of the processes. The reason for this may be the fact that the aggregates formed by freezing are relatively weak and the changes are rather instabile. So, the results achieved for example by different wet sieving procedures or by procedures including effects of water in general seldom serve as the basis of a quantitative interpretation of the mechanism of freezing.

The qualitative analyses are, however, important as they interpret the behaviour of soil at certain reduced conditions and, thus, indicate the possible behaviour also in natural circumstances in the field. In this sense the results of certain qualitative analyses have also been presented in this study. 


\section{Soil stability}

A quite clear result achieved by the analyses was that the freezing performed to the soil at the soil water potentials of -0.02 and -0.1 bar caused a diminishing of the water content retained at -0.1 to -0.01 bar compared to the specimen not frozen. The corresponding result has been achieved e.g. by Domby and Kohnke (1955) and Leo (1963). According to Hinman and Bisal (1973), the percolation rate at alternate freezing and thawing decreased at a high moisture content $(-0.1$ bar) but increased at -0.33 bar. It is apparent that one factor causing this type of behaviour is the mutual instability of the primary and secondary particles in the untreated specimen, as has been pointed out by RICHARDSON (1976) on the basis of electron micrographs of suspended soils. Ice formation in this system will cause the soil particles, particularly the ones very next to the ice formed, to move and thus to lose their instability, making the new arrangement more dense than the former one. It is also possible that the thawing of ice followed by a new distribution of water within the specimen may also cause the particles to move into a more stabile postition. It can be understood thus that when studying the effects of soil frost by employing the methods including the effects of additional water, the results achieved are no longer purely effects of freezing, but also effects of additional water. It seems thus obvious that, for example, by employing a water retention analysis, the results do not represent exactly the effects of freezing only, though they qualitatively may show the possible behaviour of soil in field in certain conditions.

In the same way as the water retention analysis is qualitative by nature, also the different sieving methods, wet or dry sievings and water drop analysis have a similar nature. It seems that the wet sieving analysis is the most widely used in evaluating the freezing effects on soil aggregates. The results of wet sievings achieved in this study were analogous to the studies existing in the literature. Thus, the disruptive effect of freezing has been evident at the soil water potentials of -0.06 and -0.34 bar. At the lower water potentials, freezing had no effect. This result is understandable, first, on the basis of the dependence of the freezing point on the soil water potential (Schofield 1935, Williams 1967). Second, smaller amounts of water will cause the degree of diverging of soil particles to diminish, as was shown by the determinations of total pore volumes of moist aggregates. Therefore, in wet soil the disruptive effect of freezing is relatively still stronger than in drier soil.

In the wet sieving experiments employed in this study, the aggregates were let to thaw before air drying. According to the results of the water retention analysis, a natural consequence of these processes is that the particles collapse into a more dense conformation. Obviously the disruptive effect of ice has, however, been strong enough at these highest water potentials for the water formed by thawing of ice not to eliminate the large cleaves formed by freezing and thus to disrupt the aggregates.

The number of freezing cycles had surprisingly little significance on the results of wet sieving. Only at the temperature of $-25^{\circ} \mathrm{C}$ the increase of the number of freezing cycles from 5 to 25 seemed to increase the breakdown of 
aggregates, but at $-5^{\circ} \mathrm{C}$ this could not be observed. Although it cannot be concluded on the basis of the data available exactly, why the disruptive effect of the temperature of $-5^{\circ} \mathrm{C}$ has stopped at five cycles whereas that of $-25^{\circ} \mathrm{C}$ has not, the speed of freezing could be one reason. It may be possible that at fast freezing the formation of new freezing centres within the aggregate as the number of freezing cycles increases is more obvious than at slow freezing. In general, at fast freezing there are more freezing centres than at slow freezing, because there are more sites for freezing to begin at lower temperatures than there are at higher ones, which is simply due to the water potential (ANDERson 1968). So, at a fast freezing it is possible that the freezing centre is not necessarily at the same point at each freezing cycle, because of the freezing speed and the movement of water due to ice formation.

At slow freezing, e.g. $-5^{\circ} \mathrm{C}$, as was the case in this study, it can be supposed that if an ice lense forms at the first freezing cycle, an ice lense probably forms at the second freezing cycle in the same site, too, if the freezing temperature and soil water contents are the same. It is probable that the cleavage formed at the very first freezing is a source of a new ice lense formation, because the water potential apparently is in this part of the soil higher than in the soil immediately around it. This makes it easy to understand the statement of LOGSDAIL and WEBBER (1959), according to which the greatest breakdown of aggregates occurrs at the first freezing cycle. So in this case, too, the strongest breakdown of the aggregates may have occured at the temperature of $-5^{\circ} \mathrm{C}$, already during the first freezing cycle (cf. Table 5). At the temperature of $-25^{\circ} \mathrm{C}$, freezing may have been, on the contrary, faster and the formation of ice more occasional compared to $-5^{\circ} \mathrm{C}$ and therefore the amounts of moved water have remained smaller. As a consequence, ice has formed all over the aggregate instead of big lenses, which has made the disruption more total (BRYAN 1971).

\section{Soil aggregation}

The situation in the soil in respect to the moisture content seems, according to this stydy, essentially to determine the soil structure and particularly the porosity. It is possible that the total pore volume of soil will not increase by freezing very much from the pore volume of moist soil, if it increases at all. The soil may reach its maximum porosity already when moist and the effect of freezing on the soil porosity may, on the contrary, be even negative if the soil has thawed before drying. This could be confirmed by comparing the corresponding figures of silty clay samples at the water potential of -0.02 bar in Tables 17 and 18. But, if the situation allows the water to escape from the soil by sublimating, the increase of total pore volume may be remarkable. This increase was, however, not in this study at the water potentials of -0.02 and -0.1 bar as great as it was in the aggregates only wetted, though the increase of water volume by freezing was supposed to have reflected also on the pore volume changes of aggregates.

This result most probably is due either to the fact that the broken aggregate 
had collapsed after the escape of sice skeleton" from the aggregate pores, or the collapse had occurred at the determination of pore volume as a result of mercury pressure. Both of these possibilities, if true, indicate that the structure of soil formed by the sublimation of ice is extremely fragile. On the other hand, these results can also be interpreted as the water in soil/aggregate to be able to keep the aggregate unbroken very effectively. The results of the water drop analysis and particularly those of wet dropping actually showed the same: although the freezing had caused the aggregate to break down, a certain amount of water, however, guaranteeded that the aggregate did not break down totally.

Occasionally in the early spring, when the furrows of ploughed field partly become bare from snow, it is possible for soil water to sublimate. This may have some influence on the formation of soil structure when tillering in the spring. It can, however, be supposed with good reason that the climatic conditions existing already in the autumn before soil freezes permanently have an important effect on the structural properties of soil. As appeared already in the very beginning of this study, both in the autumn and in the spring the diurnal variations of the soil surface temperatures may be very remarkable. Basing on this observation and on the supposition that the water movement connected with the short freezing period both in the autumn and in the spring has an essential effect on soil structure, the latter part of this study mainly concentrates on water movement caused by freezing and its effects on soil porosity.

The movement of water connected with the freezing phenomenon apparently is one of the most important factors determining the structural formation. A natural consequence of this movement is that some parts of the soil get dry. This may be one reason for the effects of freezing commonly being regarded as very similar to the effects of the wetting-drying treatments (Baver et al. 1972, Soulides and Allison 1972, Richardson 1976) and, in fact, the results achieved here really agree with this opinion.

Water movement forms different types of frost structures in different soil types due to the non-similar hydraulic properties of soils (KOKKONEN 1926, Taber 1930, Beskow 1935, Penner 1956). It is typical of these frost structures that particularly in clay soils the ice lenses are horizontally located in the soil profile. But, as has been demonstrated by ERIKsson (1941) with his X-ray pictures, the formation of ice lenses is not only limited to the soil profile and they are not only horizontally positioned; their formation may be remarkable already in the micro structure of soil and their directions may vary. It is obvious that the water movement particularly in this micro structure and the formation of micro ice lenses at the very soil surface are essential factors affecting the structure of clay soils.

The circumstances in the autumn and spring make both factors appearing above possible, i.e. water movement to the soil surface because of freezing and sublimation of water. These two factors together apparently affect the breakdown of soil clods, which effect can already be seen in the ploughed clay field in the autumn after some freezing nights. This could be confirmed also with the experiments set up in this study. Already a rather short freezing time 
- three hours at $-5^{\circ} \mathrm{C}-$ had caused quite abundant water movement in all the soils studied (Fig. 12). This means that even quite a short period below the freezing temperature in the field is enough to cause soil to freeze. This conclusion is justified on the basis that water movement in a freezing system is mainly due to the hydraulic gradient as a result of ice formation and only to a minor extent to the temperature gradient (Dirksen and Miller 1966). The experiments in this study showed that $-2^{\circ} \mathrm{C}$ was only in few cases low enough for freezing to start, lower temperatures were required.

A good agreement between the observations in the field and the results of this study was in that the accumulation of water took place in a rather thin soil surface layer, about 10 to $12 \mathrm{~mm}$. In the same way, even the aggregated surface of furrow in the ploughed field, caused by "soil frost" is of about the same thickness. It seems thus obvious that the aggregating effect also on the field surface is greatly due to the moved water freezing in this surface layer.

The preliminary experiments with big soil cylinders prepared from soil paste showed that the thickness of the layer where water accumulates at freezing was to a certain extent independent from the water content in the beginning of freezing (Fig. 13). This result obviously also indicates the dominant role of the ice phase in determining the water movement towards the freezing front. Another observation, which apparently has also an essential role in determining the soil structure, is the fact that the inner parts of a big soil cylinder have remained more wet when freezing wet soil than when freezing drier soil. This fact actually is due to the role of ice phase in determining the water movement, the speed of movement being apparently about the same at the moisture contents inspected. The curves further show that this speed has not been great enough to ensure all the mobile water inside the cylinder to move to the edges of the cylinder, but it has frozen on the spot, thus affecting the soil structure. It has been pointed out e.g. by Dirksen and Miller (1966) and HoEkstra (1967) that the movement of water may take place very fast, which result in fact was achieved also in this study. It seems, however, obvious that in few cases the entire mobile water is able to move to the freezing front, but it freezes on the spot and thus the ice formed affects the structure formation.

\section{Conclusions}

When discussing soil structure and particularly the soil pore volume, it seems on the basis of the results achieved in this study that the deteriorative measures on the soil, e.g. different compaction procedures, were not under the climatic conditions of Finland very detrimental as to the soil structure. The pore volume reversion seems to occur quite effortlessly even after a rather strong compaction, and so did the pore volume of the inner part of soil cylinder, short of water as the consequence of ice formation. At the water potentials of -0.3 to -1.0 bar the soil compaction seemed to be the most detrimental. At potentials higher than $-0.3 \mathrm{bar}$, the freezing very effectively eliminated compaction which had occurred in the soil without freezing (Fig. 14.). Accord- 
ing to this, it seems that the compaction of wet soil is not so dangerous as far as the soil pore volume is concerned. But it seems to be more dangerous, if the soil dries without freezing. The compaction of a soil drier than -1.0 bar seems not to be so dangerous, but freezing had no effect either.

The research material does not allow any far reaching generalizations because of its concisness. But consisting, however, of samples in which the effects of freezing have been apparent, and the type of soils being rather common in certain parts of Finland, some general conclusions can be drawn.

On the basis of the suppositions, according to which the climatic conditions in the autumn may affect greatly what structure the ploughed field will have the following spring, it seems obvious that to enhance the effects of nsoil frost" it is important to enhance the effects occurring also in the autumn. One way would be to plough the fields so that the soil surface area, through which the heat of soil may flow out in the cold nights is as large as possible. This means that the ploughs, which break the furrow would be better for clay fields than the ploughs, which do not break the furrow. The large surface, area would then ensure accumulation of ice also on a large area and thus the positive effect of freezing would be enhanced.

In the spring the fields are often flooded. As appeared also in this study, the water forming by the thawing of ice may effectively eliminate the aggregating effects of freezing. There are, however, no great reasons to fear that the floods would be able to eliminate all the positive effects of freezing. Despite the fact that the wet sieving analyses employed in this study were simplified and left room for interpretation, the results achieved showed that the positive effects of freezing may remain in the ploughed field to some degree at least in spite of the excess water.

This study does not support the endeavours to cultivate clay soils without ploughing in the autumn, if a good seedbed is striven for. In addition, already the very early measurements in the beginning of this study concerning soil temperatures and the depths of frost showed that the fields not ploughed were not better, rather the contrary. The reason is natural: by enhancing the loosening effect of ploughing (KERÄNEN 1924), the frost, by breaking the dense soil, also enhances the infiltration of excess water (KEso 1936) thus ensuring a quicker warming up of the soil. 


\section{Summary}

In the present study the effects of moisture and freezing on some physical properties of clay soils are under discussion. The study can be divided into two parts, the first consisting of field observations and the second of laboratory experiments.

In the field experiments, made at two sites in the south of Finland, Helsinki $\left(60^{\circ} 14^{\prime} \mathrm{N}\right)$ and Kiikala $\left(60^{\circ} 27^{\prime} \mathrm{N}\right)$, the soil types of the fields being silty clay, the temperature measurements showed remarkable daily variations. An important observation was the sinking of temperature below freezing point numerous times both in the autumn and spring. The variations were limited to a very thin surface layer only.

The depth of soil frost was in the winters the measurements were made deepest in the ploughed field. If the soil surface was covered with some insulating material, it prevented the frost from penetrating as deep as in a ploughed field, but it effectively slowed up the thawing of frost and in general the warming up of soil in the spring, too. The thawing of soil frost would take place in the soil covered with straw up to two weeks later than in a ploughed field.

The laboratory analyses were made with soil material consisting of four heavy clay samples and four silty clay samples, all samples taken from a surface layer of the field. These analyses factually consisted of qualitative analyses including water retention analyses, wet and dry sieving analyses and a water drop analysis as well as quantitative analyses. These last analyses included measurements of total pore volumes after different treatments and measurements of the amounts of water moved because of freezing.

The amounts of water retained particularly at the highest water potentials, -0.001 to -0.1 bar, were diminished both in the undisturbed samples and also in the disturbed samples, while the air volume of undisturbed samples was increased. The effects of wetting-drying treatments were similar to the freezing treatments.

The wet and dry sievings both showed that the $5-10-\mathrm{mm}$ aggregates disrupted more effectively when frozen at the water potential of -0.06 bar than at a lower potential. The heavy clay aggregates tended to break down even at the potential of -0.34 bar. The temperature of $-25^{\circ} \mathrm{C}$ had a stronger disruptive effect than $-5^{\circ} \mathrm{C}$ on the heavy clay aggregates and at the potential of -0.06 bar only. This result was more evident at dry sieving than at wet sieving. Even the disruptive effect of the wetting-drying treatment, being 
similar to that of freezing treatment, appeared more evidently at dry sieving than at wet sieving.

The increase of number of freezing cycles enhanced the disrupting effect at the freezing temperature of $-25^{\circ} \mathrm{C}$ more effectively than at $-5^{\circ} \mathrm{C}$, the water potential being -0.34 bar, when the aggregate stability was analyzed with sievings.

By analyzing the aggregate stability with the water drop analysis the water potentials required for aggregate disruption by freezing were -0.06 and -0.34 bar. The effects of the two freezing temperatures, $-5^{\circ} \mathrm{C}$ and $-25^{\circ} \mathrm{C}$, were similar and even the wetting-drying treatment as disrupting agent was similar to the freezing treatment. The increase of number of freezing cycles had no effect on the results of water drop analyses, the water potential at freezing being -0.34 bar.

The total pore volume of $5-10-\mathrm{mm}$ heavy clay aggregates was almost linearly dependent on the water potential from air dry up to -0.1 bar at which potential the increase ceased. The increase of the total pore volume of heavy clay aggregates was about 20 percentage units, when the water potential was increased from air dry to -0.02 bar. In the silty clay aggregates the increase of water potential from air dry to $\mathbf{- 1 5 . 0}$ bar had not caused any increase of pore volume, but at the potential of -15.0 to -0.02 bar there was a rather straightforward dependence between these two variables. At its highest, at the potential of $-0.02 \mathrm{bar}$, the increase of total pore volume was about 12 to 17 percentage units.

The effect of freezing on the total pore volume of aggregates was very negligible if the aggregates were let to thaw before drying. For the heavy clay aggregates the increase was about 2 to 3 percentage units and for the silty clay aggregates about 1 percentage unit, when the water potential was -0.1 to -0.02 bar at freezing $\left(-5^{\circ} \mathrm{C}\right)$. If the aggregates were only moistened to the corresponding potentials and let to dry without freezing the increases were almost equal.

If the ice was let to sublimate from the frozen aggregate, the total pore volume increased significantly from that of the air dry aggregates. The increase was, however, not so great as it was in the aggregates only moistened. For heavy clay aggregates it was about 9 to 13 percentage units at the potential of $-\mathbf{0 . 0 2}$ bar. The corresponding figures for the silty clay aggregates were about 5 to 7 percentage units. Even at the potential of $-\mathbf{1 5 . 0}$ bar there was an increase of about 2 to 5 percentage units for the heavy clay aggregates, while the silty clay aggregates showed no increase at this potential.

In the latter part of the study, the movement of water due to ice formation is studied. The experiments were performed either with small soil cylinders, $25 \mathrm{~mm}$ in diameter and $10 \mathrm{~mm}$ in height or with bigger ones, $85 \mathrm{~mm}$ in diameter and $35 \mathrm{~mm}$ in height. In the small cylinders the moisture content difference between the inner and outer parts of soil cylinder showed almost a linear dependence on the water potential at freezing. The correlation coefficient between these two variables was $r=0.96 * * *$ for heavy clay cylinders and $\mathrm{r}=0.93^{* * *}$ for silty clay cylinders. The freezing temperature was $-5^{\circ} \mathrm{C}$. The movement of water ceased in the heavy clay cylinders at the water potential 
of -2.0 to -4.0 bar and in the silty clay cylinders at -3.0 to -8.0 bar. The temperature of $-2^{\circ} \mathrm{C}$ was not in all cases low enough to cause the soil cylinder to freeze and thus the water to move.

The results achieved with big soil cylinders showed that already a threehour freezing at a temperature of $-5^{\circ} \mathrm{C}$ caused significant water movement. A 16-hour freezing was long enough to cause the same effect as the one-week freezing. Three hours of freezing caused a difference in moisture content of about 5 to 7 percentage units between the outer and the inmost part of soil cylinder and the 16 -hour freezing about 13 to 28 percentage units, when the water potential in the beginning of freezing was -0.1 bar.

The accumulation of water in a rather thin surface layer of the soil cylinder caused a significant increase in the total pore volume in this part of the soil cylinder. But in spite of the water escaping from the inner parts of the soil cylinder, the total pore volumes of these parts were, however, after the treatments greater than those of the corresponding soil cylinders not frozen, only air dried. This result presupposed, however, that the water potential exceeded -1.0 bar in the beginning of freezing. At a lower water potential the positive effect of freezing was in general non-significant. The most obvious positive effect was to be seen in the heavy clay samples, and particularly in those, low in organic carbon content. On the basis of these results, it could be concluded that the compaction of heavy clay soils is in Finnish climatic conditions not very detrimental because of the strong ameliorating effect of soil frost. 


\section{REFERENCES}

Agerberg, L. S. 1948. Snö och tjäle. Grundförbättring 2: 235-246.

ANDERson, D. M. 1968. Undercooling, freezing point depression, and ice nucleation of soil water. Israel J. Chem. 6: 349-355.

ANDERsson, S. 1964. Markfysikaliska undersökningar i odlad jord. XV. Undersökningar av tjälbildning, tjäldjup och tjälavsmältning i olika åkermarker med och utan snötäcke. Grundförbättring 17: 187-216.

AURA, E. 1975. Effects of soil moisture on the germination and emergence of sugar beet (Beta vulgaris L.). J. Scient. Agric. Soc. Finl. 47:1-70.

BASAK, P. 1972. Soil structure and its effects on hydraulic conductivity. Soil Sci. 114: 417422.

Baver, L. D., Gardner, W. H. \& Gardner, W. R. 1972. Soil physics. 498 p. New York.

Benoit, G. R. 1973. Effect of freeze-thaw cycles on aggregate stability and hydraulic conductivity of three aggregate sizes. Soil Sci. Soc. Amer. Proc. 37: 3-5.

- \& Bornstein, J. 1970. Freezing and thawing effects on drainage. Soil Sci. Soc. Amer. Proc. 34: 551-557.

BEskow, G. 1935. Tjälbildningen och tjällyftningen med skärskild hänsyn till vägar och järnvägar. Sv. Geol. Undersök. Ser. C. N:o 375.

Birecki, M., Kullmann, A., Revut, I. B. \& Rode, A. A. 1968. Untersuchungsmethoden des Bodenstrukturzustandes. 503 p. Berlin.

Bisal, F. \& Ferguson, W. S. 1968. Monthly and yearly changes in aggregate sizes of surface soils. Can. J. Soil Sci. 48: 159-164.

- \& Nielsen, K. F. 1967. Effect of frost action on the size of soil aggregates. Soil Sci. 104: $268-272$.

Blake, G. R. 1965 a. Bulk density. Agronomy 9:374-390.

- 1965 b. Particle density. Agronomy 9: 371-373.

- \& Nelson, W. W. \& Allamaras, R. R. 1976. Persistence of subsoil compaction in a Mollisol. Soil Sci. Soc. Amer. J. 40: 943-948.

Bouyoucos, G. J. 1935. A method for making mechanical analysis of the ultimate natural structure of soils. Soil Sci. 40: 481-485.

Bryan, R. B. 1971. The influence of frost action on soil-aggregate stability. Trans. Inst. British Geograph. 54: 71-88.

Bryant, J. C., Bendixen, J. W. \& Slater, C. S. 1948. Measurements of the water stability of soil. Soil Sci. 65: $341-345$.

CHEPIL, W. S. 1952. Improved rotary sieve for measuring state and stability of dry soil structure. Soil Sci. Soc. Amer. Proc. 16: 113-117.

CHEPIL, W. S. 1954. Seasonal fluctuations in soil structure and erodibility of soil by wind. Soil Sci. Soc. Amer. Proc. 18: 13-16.

- 1962. A compact rotary sieve and the importance of dry sieving in physical soil analysis. Soil Sci. Soc. Amer. Proc. 26: 4-6.

Czeratzki, W. 1956. Zur Wirkung des Frostes auf die Struktur des Bodens. Z. Pfl.ern. Düng. Bodenk. 72: $15-32$.

- 1971. Die Bedeutung des Bodenfrostes für den Ackerbau und speziell für die Bodenbearbeitung. Landbauforschung Völkenrode 21:1-12.

Detrmann, M. G. 1958. Water uptake by pure clays and soil crumbs. J. Soil Sci. 9: 306-315. 
Dirksen, C. \& Miller, R. D. 1966. Closed-system freezing of unsaturated soil. Soil Sci. Soc. Amer. Proc. 30: 168-173.

Domby, C. W. \& Koнnke, H. 1955. The effect of freezing and thawing on structure of the soil surface. Agron. J. 47: 175-177.

Duncan, D. B. 1955. Multiple range and multiple F tests. Biometrics 11: 1-42.

Elonen, P. 1971. Particle-size analysis of soil. Acta Agr. Fenn. 122: 1-122.

EMERSon, W. W. 1978. Aggregate classification and the hydraulic conductivity of compacted subsoils. pp. 239-248. In Modification of soil structure. Ed. Emerson, W. W., Bond, R. D. \& Dexter, A. R. 438 p. New York.

ERIKsson, S. 1941. Über die Einwirkung des Frostes auf die Struktur der Lehm- und Tonböden. Ann. Agric. Coll. Sweden 9: 80-115.

Ferguson, H., Brown, P. L. \& Dickey, D. D. 1964. Water movement and loss under frozen soil conditions. Soil Sci. Soc. Amer. Proc. 28: 700-703.

GANDAHL, R. 1957. Bestämning av tjälgräns i mark med enkel typ av tjälgränsmätare. Grundförbättring 10: 7-19.

Ghadiri, H. \& PAYNe, D. 1977. Raindrop impact stress and the breakdown of soil crumbs. J. Soil Sci. 28: 247-258.

Graham, E. R. 1948. Determination of soil organic matter by means of a photoelectric colorimeter. Soil Sci. 65: 181-183.

Haines, W. R. 1923. The volume changes associated with variations of water content in soil. J. Agric. Sci. 13: 296-310.

Hartge, K. H. 1965. Die Bestimmung von Porenvolumen und Porengrössenverteilung. Z. Kulturtechnik 4: 193-206.

Heinonen, R. 1961. On the pretreatment of samples of heavy clay soil for determinations by the pressure membrane apparatus. J. Scient. Agric. Soc. Finl. 33: 153-158.

Henriksson, L. 1971. Tilljämning av plogtiltan på hösten. Försök med höstharvning och tillsatsredskap till plogen. Sv. Lantbrukshögsk. Rapporter från jordbearbetningsavdelningen 24: 1-68.

Hinman, W. C. \& Bisal, F. 1968. Alternations of soil structure upon freezing and thawing and subsequent drying. Can. J. Soil Sci. 48: 193-197.

- \& Bisal, F. 1973. Percolation rate as affected by the interaction of freezing and drying processes of soils. Soil Sci. 115: 102-106.

Hoekstra, P. 1967. Moisture movement to a freezing front. Extract of $₫$ Geochemistry, Precipitation, Evaporation, Soil-moisture, Hydrometryi. General Assembly of Bern. pp. $411-417$.

- 1969. Water movement and freezing pressures. Soil Sci. Soc. Amer. Proc. 33: 512 - 518.

Homén, Th. 1893. Om nattfroster. 208 p. Helsingfors.

- 1896. Uber die Bodentemperatur in Mustiala. 183 p. Helsingfors.

- 1897. Der Tägliche Wärmeumsatz im Boden und die Wärmestrahlung zwischen Himmel und Erde. 146 p. Helsingfors.

Jung, E. 1931 a. Neue Experimentaluntersuchungen über die Aggregierende Wirkung des Frostes auf den Erdboden. Kolloidchemische Beihefte 32:320-373.

- 1931 b. Untersuchungen über die Einwirkung des Frostes auf den Erdboden. Z. Pfl.ern. Düng. Bodenk. 19: 326-333.

JUUSELA, T. 1941. Viljelysmaiden routaantumisesta ja salaojituksen vaikutuksesta roudan muodostumiseen ja sulamiseen. J. Scient. Agric. Soc. Finl. 13: 81-95.

- 1945. Untersuchungen über den Einfluss des Entwässerungsverfahrens auf den Wassergehalt des Bodens, den Bodenfrost und die Bodentemperatur. Acta Agr. Fenn. 59: $1-212$.

- 1947. Salaojituskysymyksen selvittelyä. J. Scient. Agric. Soc. Finl. 19:60-68.

KaILA, A. 1952. Influence of legumes upon soil fertility. Ann. Acad. Sci. Fenn. Ser. A II 42: $1-39$.

Kemper, W. D. \& ChepiL, W. S. 1965. Size distribution of aggregates. Agronomy 9: 499-510,

KerÄNEN, J. 1920. Uber die Temperatur des Bodens und der Schneedecke in Sodankylä nach Beobachtungen mit Thermoelementen. Ann. Acad. Sci. Fenn. Ser. A XIII N:o 7. 
- 1923 a. Beiträge zur Kenntnis des Frostes in Erdboden. Ann. Acad. Sci. Fenn. Ser. A XX N:o 6 .

- 1923 b. Uber den Bodenfrost in Finnland. Mitt. Meteorol. Zentralanstalt Finn. Staates N:o 12.

- 1924. Maankamaran routaantuminen. Oma Maa V: 953-964.

KEso, L. 1936. Beobachtungen über den Dränabfluss in Tonböden und in gefrorenen Böden. V Hydrol. Konf. Baltischen Staat. Mitt. 4 B.

- 1951. Salaojitusmenetelmistä. J. Scient. Agric. Soc. Finl. 23: 164-181.

KoEPF, H. 1956. Apparatur zur Bestimmung der Krümelstabilität. Z. Pfl.ern. Düng. Bodenk. 74: $144-157$.

KоккоNen, P. 1924. Tutkimuksia viemärien kuntoon vaikuttavista seikoista. Acta Forest. Fenn. 27: 1-220.

- 1926. Beobachtungen über die Struktur des Bodenfrostes. Acta Forest. Fenn. 30: 1-56.

- 1929. Maanviljelysteknillisestä tutkimustyöstä ja sen edistämisestä. J. Scient. Agric. Soc. Finl. 13: 60-72.

- 1942. Havaintoja viime talven roudasta ja sen sulamisesta sekä sen vaikutuksesta viljelykseen. J. Scient. Agric. Soc. Finl. 14: 80-110.

- 1944. Roudasta ja sen merkityksestä. pp. 135-158. Suomalainen Tiedeakatemia. Esitelmät ja Pöytäkirjat 1944. Helsinki 1945.

Lemströм, S. 1893. Om nattfrosterna och medlen att förekomma deras hjärningar. 72 p. Helsingfors.

LEO, M. W. M. 1963. Effect of freezing and thawing on some physical properties of soils as related to tomato and barley plants. Soil Sci. 96: 267-274.

Logsdait, D. E. \& WebBer, L. R. 1959. Effect of frost action on structure of Haldimand clay. Can. J. Soil Sci. 39: 103-106.

Low, A. J. 1954. The study of soil structure in the field and the laboratory. J. Soil Sci. 5: 5774.

Martin, R. T. 1959. Rhytmic ice banding in soil. Highway Res. Board Bull. 218: 11-23.

Mc Calla, T. M. 1944. Water-drop-method of determining stability of soil structure. Soil Sci. 58: $117-121$.

McLeod, H. E., Reed, I. F., Johnson, W. H. \& Gill, W. R. 1966. Draft, power efficiency, and soil-compaction characteristics of single, dual and low-pressure tires. Transactions of ASAE 9: 41-44.

Meyer, L. \& v. RennenkampfF, U. 1936. Neuer Apparat und Methode zur automatischen Durchführung der Krümelanalyse nach Tjulin und Vorschläge zur Bestimmung des Krümelanteils, der Krümelgrössen und der Krümelfähigkeit des Bodens. Z. Pfl.ern. Düng. Bodenk. 43: 268-280.

Miller, R. D., Loch, J. P. G. \& Breisler, E. 1975. Transport of water and heat in a frozen permeameter. Soil Sci. Soc. Amer. Proc. 39: 1029-1036.

NJøs, A. 1959. Regenapparat für die Bestimmung der Wasserstabilität des Bodens. Z. Pfl.ern. Düng. Bodenk. 87: 236-243.

Penner, R. E. 1956. Soil moisture movement during ice segregation. Highway Res. Board Bull. 135: 109-118.

PETIT, A. 1893. Untersuchungen über den Einfluss des Frostes auf die Temperaturverhältnisse der Böden von verschiedenen physikalischen Beschaffenheit. pp. 285-310. In Forschungen auf dem Gebiete der Agrikultur Physik. Ed. WollnY, E. vol. XVI 501 p. Heidelberg.

Richards, L. A. 1948. Porous plate apparatus for measuring moisture retention and transmission by soil. Soil Sci. $66: 105-110$.

- 1949. Methods of measuring soil moisture tension. Soil Sci. 68: 95-112.

Richardson, S. J. 1976. Effect of artificial weathering cycles on the structural stability of a dispersed silt soil. J. Soil Sci. 27: 287-294.

Rose, G. W. 1960. Soil detachment caused by rainfall. Soil Sci. 89: 28-35.

Rytr, R. 1965. On the determination of soil pH. J. Scient. Agric. Soc. Finl. 37: 51-60.

Saini, G. R. ,Maclean, A. A. \& Doyle, J. J. 1966. The influence of some physical and chemical properties on soil aggregation and response to VAMA. Can. J. Soil. Sci. 46: 155-160. 
Schaller, F. W. \& Stockinger, K. R. 1953. A comparison of five methods for expressing aggregation data. Soil Sci. Soc. Amer. Proc. 17: 310-313.

Schofield, R. K. 1935. The pF of the water in soil. Trans 3rd Int. Congr. Soil Sci. 2: 37-48.

Sekera, F. \& Brunner, A. 1943. Beiträge zur Methodik der Gareforschung. Bodenk. u. Pfl.ern. 29: 169-212.

Sillanpää, M. 1961. The dynamic nature of soil aggregation as affected by cycles of freezing and thawing. Acta Agric. Scand. 11: 87-94.

- \& WebBer, L. R. 1961. The effect of freezing-thawing and wetting-drying cycles on soil aggregation. Can. J. Soil Sci. 41: 182-187.

Simola, E. F. 1923. Huomioita viljellyn hieta-, savi- ja mutamaan kirren sulamisesta Maanviljelystaloudellisella Koelaitoksella vuosina 1922 ja 1923. Suom. Maanvilj.taloud. Koelait. Tiet. Julk. N:o 21.

- 1926. Tutkimuksia viljelysmaiden jäätymisestä ja kirren sulamisesta Maatalouskoelaitoksella. Valt. Maatal.koetoim. Julk. N:o 5.

- 1930. Kirsi- ja vajovesisuhteiden tutkimuksia Maatalouskoelaitoksella ja osittain myös muualla Suomessa vuosina 1926-1929. Valt. Maatal.koetoim. Julk. N:o 30.

Slater, C. S. \& Hopp, H. 1949. The action of frost on the water-stability of soils. J. Agric. Res. 78: $341-346$.

Sloneker, L. L., Olson, T. C. \& Moldenhauer, W. C. 1976. Effect of pore water pressure on sand splash. Soil Sci. Soc. Amer. J. 40: 948-951.

Smith, R. H. \& Cernuda, R. M. 1951. Some applications of water-drop stability testing to tropical soils of Puerto Rico. Soil Sci. 71: $337-345$.

Soulides, D. A. \& Allison, F. E. 1961. Effect of drying and freezing soils on carbon dioxide production, available mineral nutrients, aggregation, and bacterial population. Soil Sci. 91: $291-298$.

Soveri, J. \& VARJo, M. 1977. Roudan muodostumisesta ja esiintymisestä Suomessa vuosina 1955-1975. Publ. Water Res. Instit. 20.

Soveri, U. \& Johansson, S. 1966. Havaintoja lumesta raivatun maan routaantumisesta ja sulamisesta Suomessa v. 1958-1964. Valt. Tekn. Tutk.lait. Julk. 107.

StIRK, G. B. 1954. Some aspects of soil shrinkage and the effect of cracking upon water entry into the soil. Aust. J. Agr. Res. 5: 279-290.

Sunkel, R. 1960. UUber die Porosität von Bodenaggregaten 1. Mitteilung: Eine Methode zur Bestimmung des Substanz- und Porenvolumens von Bodenaggregaten. Z. Pfl.ern. Düng. Bodenk. 89: 17-27.

- 1964. Uber die Porosität von Bodenaggregaten 4. Mitteilung: Die Porengrösse in Abhängigkeit von Quellung und Schrumpfung. Z. Pfl.ern. Düng. Bodenk. 107: 206-215.

TABER, S. 1930. The mechanics of frost heaving. J. Geol. 38: 303-317.

Tempany, H. A. 1917. The shrinkage of soils. J. Agric. Sci. 8: 312-330.

Toogood, J. A. 1978. Relation of aggregate stability to properties of Alberta soils in modification of soil structure. pp 211-215. in Modification of soil structure. Ed. EMERson, W. W., Bond, R. D. \& Dexter, A. R. 438 p. New York.

ULRICH, R. 1897/98. Untersuchungen über den Einfluss des Frostes auf die Temperaturverhältnisse des Bodens von verschiedenen Salzgehalt. pp. 218-228. in Forschungen auf dem Gebiete der Agrikultur-Physik. Ed. Wollny, E. vol. XX 538 p. Heidelberg.

VANDEnBerg, G. E. \& GiLL, W. R. 1962. Pressure distribution between a smooth tire and soil. Transaction of ASAE 5: 105-107.

WARKentin, B. P. \& BozozuK, M. 1961. Shrinking and swelling properties of two Canadian clays. 5th Int. Conf. Soil Mech. and Found. Engin. Proc. 3 A: 851-855.

Willinms, P. J. 1967. Properties and behaviour of freezing soils. Norwegian Geotechn. Instit. Publ. 74: 1-119.

WILLIs, W. O. 1955. Freezing and thawing and wetting and drying in soils treated with organic chemicals. Soil Sci. Soc. Amer. Proc. 19: 263-267.

WoLLny, E. 1897/98. Untersuchungen über den Einfluss des Frostes auf die physikalischen Eigenschaften des Bodens. pp. 439-468. in Forschungen auf dem Gebiete der Agrikultur-Physik. Ed. Wollny, E. vol. XX 538 p. Heidelberg.

YoDER, R. E. 1936. A direct method of aggregate analysis of soils and a study of the physical nature of erosion losses. J. Am. Soc. Agron. 28: 337-350. 


\title{
SELOSTUS
}

\section{Kosteuden ja jäätymisen vaikutus eräisiin muokkauskerroksesta otettujen savimaanäytteiden fysikaalisiin ominaisuuksiin}

\author{
Simo KivisaARI \\ Yliopiston maanviljelyskemian laitos, Helsinki
}

Tämän tutkimuksen tarkoituksena oli selvittää, mitkä ovat niitä tekijöitä, joiden vaikutuksesta savimaiden pinta talven aikana muuttuu. Tutkimus jakautuu kahteen osaan, joista ensimmäinen käsittelee kentällä tehtyjä havaintoja ja toinen laboratoriossa tehtyjä mittauksia.

Kenttäkokeet tehtiin Helsingissä ja Kiikalassa, joissa kummassakin koealan pinta oli lähinnä hiesusavea. Lämpötilamittaukset osoittivat, että vuorokautiset lämpötilavaihtelut saattoivat olla sekä syksyllä että keväällä erittäin suuria etenkin aivan maan pinnassa. Merkille pantavaa oli, että kumpanakin vuodenaikana lämpötila saattoi laskea lukuisia kertoja $0^{\circ} \mathrm{C}$ alapuolelle.

Routa tunkeutui talven aikana syvimmälle kynnetyssä maassa. Mikäli maa oli peitetty jollain katteella tai jätetty kyntämättä, roudan syvyys jäi pienemmäksi, mutta katteen vaikutuksesta se kokonaisuudessaan suli myöhemmin ja maa siten myös lämpeni hitaammin.

Laboratoriossa tutkittavana ollut näyteaineisto koostui kahdeksasta pintamaanäytteestä, joista neljä kuului aitosaviin ja toiset neljä hiesusaviin. Analyysimenetelmät jakaantuivat lähinnä kahteen osaan ensimmäisen osan koostuessa kvalitatiivisista menetelmistä. Näitä olivat maan vedenpidätysanalyysi, märkä- ja kuivaseulonta-analyysi sekä pisarointianalyysi. Jälkimmäisessä osassa tarkasteltiin maan huokostilavuuden muuttumista erilaisten käsittelyjen vaikutuksesta sekä sitä, mikä osuus on jäätymisen aiheuttamalla veden liikkumisella maan huokoisuuden muuttumiseen.

Jäätyminen vaikutti $-0.001-0.1$ bar veden potentiaalilla pidättyneen veden määrää vähentävästi sekä häiriintymättömillä lieriönäytteillä että rikotuilla näytteillä aiheuttaen samalla sen, että edellisten ilmatila kasvoi.

Sekä kuiva- että märkäseulonta kumpikin osoittivat, että 5-10 mm aggregaatit rikkoontuivat jäädytyksen vaikutuksesta herkemmin -0.06 bar veden potentiaalissa kuin sitä alhaisemmissa. Aitosaviaggregaateilla vielä -0.34 bar potentiaali oli riittävän korkea aiheuttamaan rikkoontumisen. -0.06 bar potentiaalissa $-25^{\circ} \mathrm{C}$ lämpötilan vaikutus oli voimakkaampi kuin $-5^{\circ} \mathrm{C}$. Kostutus-kuivatus käsittelyn vaikutus oli yleensä hyvin samansuuntainen jäädytyskäsittelyjen kanssa tämänkaltaisten tulosten tullessa selvimmin esille kuivaseulonta-analyyseissä.

Jäädytyskertojen lisääminen viidestä 25 :een lisäsi aggregaatien rikkoontuvuutta etenkin $-25^{\circ} \mathrm{C}$ lämpötilan vaikutuksesta veden potentiaalin ollessa jäädytettäessä -0.34 bar, mikäli stabilisuutta analysoitiin seulonnoilla. Pisarointianalyyseissä tätä ei voitu todeta. Muilta osin pisarointianalyysin tulokset olivat lähes vastaavia seulonta-analyysien tulosten kanssa.

5-10 mm aitosaviaggregaattien huokostilavuus oli lähes lineaarisesti riippuvainen veden potentiaalista välillä ilmakuiva --0.1 bar. -0.1 bar potentia alissa huokostilavuuden kasvu heikkeni märempään päin siirryttäessä. Huokostilavuuden kasvu oli näillä ilmakuivasta -0.02 bar veden potentiaaliin noin 20 prosenttiyksikköä. Hiesusavilla veden potentiaalin nostaminen ilmakuivasta -15.0 bariin ei aiheuttanut huokostilavuudessa kasvua, mutta välillä 
-15.0 bar --0.02 bar riippuvuus oli lähes suoraviivainen. -0.02 bar potentiaalissa näillä oli tapahtunut huokostilavuuden kasvua noin $12-17$ prosenttiyksikköä ilmakuivaan verrattuna.

Jäätymisen vaikutus aggregaattien huokostilavuuden kasvuun oli erittäin vähäinen, mikäli näyte sai sulaa ennen kuivumista. Aitosaviaggregaateilla tämä kasvu oli parhaimmillaankin vain noin $2-3$ prosenttiyksikköä ja hiesusaviaggregaateilla noin 1 prosenttiyksikkö. Pelkällä kostutus-kuivatuskäsittelyllä oli kutakuinkin sama vaikutus.

Jos jää sai poistua aggregaatista sublimoitumalla, jäätymisen vaikutus huokostilavuuden lisääjänä muodostui huomattavasti voimakkaammaksi. Aitosavilla tämä lisäys oli -0.02 bar veden potentiaalissa noin $9-13$ prosenttiyksikköä ja hiesusavilla noin 5-7 prosenttiyksikköä jääden siten kummassakin maalajiryhmässä vähäisemmäksi kuin huokostilavuuden lisäys pelkän kostutuksen vaikutuksesta.

Veden liikkumista maassa jään muodostumisen vaikutuksesta tutkittiin kahden kokoisilla maalieriöillä. Pienemmillä $25 \mathrm{~mm}$ :n läpimittaisilla lieriöillä voitiin todeta, että lieriön sisäja ulko-osan välinen jäätymisen vaikutuksesta muodostuva kosteusero oli lähes lineaarisesti riippuvainen veden potentiaalista jäädytyshetkellä. Veden liikkumisen voitiin todeta loppuneen aitosavilieriöillä noin $-2.0--4.0$ bar veden potentiaalissa jäädytyslämpötilan ollessa $-5^{\circ} \mathrm{C}$. Vastaavat luvut hiesusavilla olivat $-3.0--8.0$ bar.

$-2^{\circ} \mathrm{C}$ lämpötila ei kaikissa tapauksissa ollut riittävän alhainen aiheuttamaan lieriön jäätymistä.

Isoilla $85 \mathrm{~mm}: \mathrm{n}$ läpimittaisilla maalieriöillä tehdyt kokeet osoittivat, että jo kolmen tunnin jäädytys $-5^{\circ} \mathrm{C}$ :ssa oli riittävä aiheuttamaan huomattavaa veden siirtymistä. 16 tunnin jäädytyksen vaikutus ei sanottavasti poikennut yhden viikon jäädytyksen vaikutuksesta. Kolmen tunnin jäädytyksen vaikutuksesta lieriön ulko- ja sisäosan väliseksi kosteuseroksi muodostui kummassakin maalajiryhmässä noin $5-7$ prosenttiyksikköä veden potentiaalin jäädytyshetkellä olleessa -0.1 bar. 16 tunnin jäädytyksessä vastaavat kosteuserot olivat $13-28$ prosenttiyksikköä.

Veden kerääntyminen lieriön pintaan aiheutti siinä selvää huokostilavuuden kasvua. Mutta, huolimatta siitä, että lieriön sisäosista poistui vettä, tämänkin huokostilavuus muodostui suuremmaksi kuin niiden koejäsenten, jotka olivat kostutuksen jälkeen suoraan kuivuneet ilman jäädytyskäsittelyä. Tämä tilanne edellytti kuitenkin, että veden potentiaali jäädytyshetkellä ylitti -1.0 bar. Alemmissa potentiaaleissa jäädytyksen merkitys oli yleensä vähäinen. Saatujen tulosten perusteella voitiin päätellä, että tiivistymisellä ei Suomen ilmasto-oloissa voida katsoa olevan kovin haitallista vaikutusta maan pintakerroksissa, jäätymisen kuohkeuttavan vaikutuksen vuoksi. 